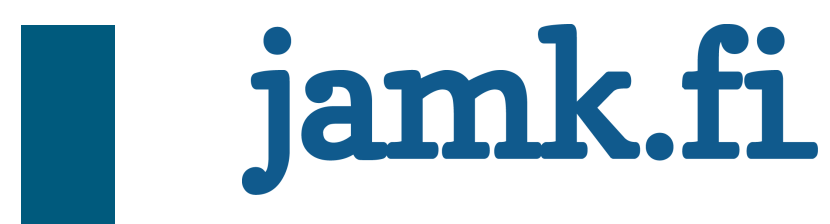

\title{
Tavoitteet nuorten mielenterveyskuntoutuksessa
}

Jonna Tolonen

Opinnäytetyö

Huhtikuu 2019

Sosiaali-, terveys- ja liikunta-ala

Sosiaali- ja terveysalan ylempi AMK tutkinto-ohjelma

Monialainen kuntoutuksen koulutusohjelma

Jyväskylän ammattikorkeakoulu

JAMK University of Applied Sciences 


\section{jamk.fi}

Kuvailulehti

\begin{tabular}{|l|l|l|}
\hline Tekijä(t) & Julkaisun laji \\
Tolonen, Jonna & Opinnäytetyö, ylempi AMK & $\begin{array}{l}\text { Päivämäärä } \\
\text { Huhtikuu } 2019\end{array}$ \\
\cline { 2 - 3 } & $\begin{array}{l}\text { Sivumäärä } \\
76\end{array}$ & $\begin{array}{l}\text { Julkaisun kieli } \\
\text { Suomi }\end{array}$ \\
\cline { 2 - 3 } & & $\begin{array}{l}\text { Verkkojulkaisulupa } \\
\text { myönnetty: } x\end{array}$ \\
\hline
\end{tabular}

Työn nimi

Tavoitteet nuorten mielenterveyskuntoutuksessa

Tutkinto-ohjelma

Toimintaterapeutti YAMK, monialainen kuntoutus

Työn ohjaaja(t)

Katja Raitio, Sanna Sihvonen

Toimeksiantaja(t)

Psykiatrisen kuntoutuksen vaikuttavuus-tutkimushanke

Tiivistelmä

Mielenterveyden häiriöt voivat vaikeuttaa nuoruuden kehitystehtävien saavuttamista ja ilman asianmukaisia interventioita aiheuttaa sosiaalista syrjäytymistä, heikentynyttä elämänlaatua sekä kuluttaa yhteiskunnallisia resursseja. Mielenterveyskuntoutuksessa keskeistä on tavoitteiden asettelu, jonka avulla voidaan vaikuttaa kuntoutujan motivaatioon ja elämänlaatuun. Kuntoutuksen tavoitteiden tulisi olla yhteydessä yksilön kehitystehtäviin. Kuntoutuksen vaikuttavuustutkimuksessa on yhteiskunnallisen ja taloudellisen tarkastelun lisäksi tärkeä huomioida kuntoutujan omien tavoitteiden merkitys.

Tutkimuksen tarkoituksena oli ymmärryksen lisääminen nuorten mielenterveyskuntoutuksessa tavoiteltavista asioista ja ilmiöistä sekä sitä kautta tavoitteiden asettelun kehittäminen. Tavoitteena oli mielenterveyskuntoutuksessa asetettujen tavoitteiden tarkasteleminen ja kuvaileminen. Laadullinen tutkimus toteutettiin käyttäen asumiskuntoutuksessa kerättyä rekisteritietoa, jota analysoitiin aineistolähtöisellä sisällönanalyysillä.

Aineistosta tunnistettiin kolme pääkategoriaa: Ikätasoiset toiminnalliset roolit, sosiaalinen osallisuus sekä sisäinen resilienssi. Toimiessaan ikätasoisten toiminnallisten rooliensa mukaisesti yksilö kykenee suuntautumaan kehitystehtäviinsä. Ikätasoiset toiminnalliset roolit viittaavat myös yksilön toimintakokonaisuuksiin. Sosiaalinen osallisuus on mahdollisuutta osallistua ympäristön toimintaan, kuten yhteiskuntaan ja yhteisöihin. Sisäinen resilienssi on psykologinen prosessi, jonka avulla yksilö pyrkii vaikeissa tilanteissa käyttämään henkilökohtaisia ominaisuuksiaan. Nämä kokonaisuudet ovat tutkimustiedon perusteella tiiviissä yhteydessä valtaistumisen, kuntoutumisen sekä toipumisen käsitteisiin. Johtopäätöksenä voidaan todeta, että nuorten mielenterveyskuntoutuksen tavoitteiden asettelussa keskeistä on kehitystehtävien huomioiminen sekä nuoren ja ammattilaisen välinen vuorovaikutussuhde.

Avainsanat (asiasanat)

nuoret, mielenterveyskuntoutus, tavoitteet, rekisteriaineisto, laadullinen tutkimus, retrospektiivinen tutkimus

Muut tiedot (salassa pidettävät liitteet) 


\section{jamk.fi}

\section{Description}

\begin{tabular}{|l|l|l|}
\hline Author(s) & Type of publication \\
Tolonen, Jonna & Master's thesis & $\begin{array}{l}\text { Date } \\
\text { April } 2019\end{array}$ \\
\cline { 2 - 3 } & & $\begin{array}{l}\text { Language of publication: } \\
\text { Finnish }\end{array}$ \\
\cline { 2 - 3 } & $\begin{array}{l}\text { Number of pages } \\
76\end{array}$ & $\begin{array}{l}\text { Permission for web publi- } \\
\text { cation: } \mathrm{x}\end{array}$ \\
\hline
\end{tabular}

Title of publication

Goals in Adolescents' Mental Health Rehabilitation

Degree programme

Master's Degree in Multidisciplinary Rehabilitation

Supervisor(s)

Katja Raitio, Sanna Sihvonen

Assigned by

The Impact of Psychiatric Rehabilitation-research project

Abstract

Mental health problems can make it difficult for the individual to achieve developmental tasks. Moreover, these difficulties without proper interventions can cause social exclusion, poor life quality and consume societal resources. Goal setting is a central part of mental health rehabilitation as it can enhance motivation and the quality of life. Rehabilitation goals should be in concordance with larger life goals and developmental tasks. In research on the impact of rehabilitation, it is important to consider the rehabilitees' goals in addition to the social and financial perspectives.

The purpose of the study was to increase the understanding of the aims of adolescents' mental health rehabilitation and encourage the development of goal setting. The aim of the study was to examine and describe the goals set in mental health rehabilitation. This qualitative study was implemented by using register information about those who were offered rehabilitative housing services. The information was analysed by using inductive content analysis.

In the data, three categories of goals could be identified: age-level occupational roles, social inclusion and inner resilience. When acting according to the age-level occupational roles, people are pursuing their developmental tasks. The concept also refers to occupations. Social inclusion is the possibility to participate in the environment, such as society and communities. Inner resilience is a psychological process which helps the individual to cope with difficult situations by using their personal skills. According to research, these phenomena are tightly connected to empowerment, rehabilitation and recovery. In conclusion, it can be stated that the key phenomena in the goal setting of adolescents' mental health rehabilitation are the consideration of developmental tasks and interaction between the adolescent and the professional.

Keywords/tags (

youth, metal health, goals, register information, qualitative study, retrospective study

Miscellaneous (Confidential information) 


\section{Sisältö}

1 Johdanto

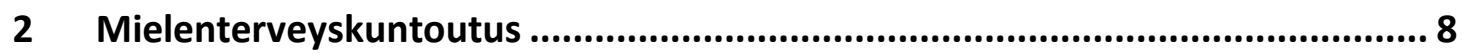

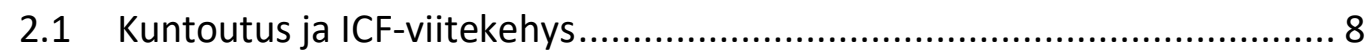

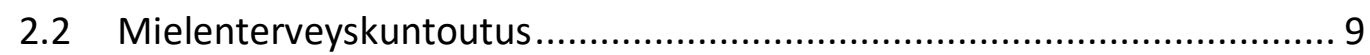

2.3 Mielenterveyskuntoutuksen interventiot tutkimuksen kohteena........... 13

3 Mielenterveyskuntoutus nuoruusiässä ...................................................... 16

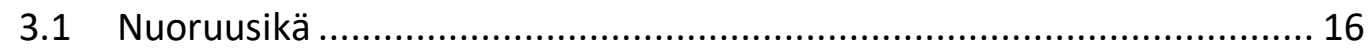

3.2 Mielenterveydenhäiriöt nuoruudessa ................................................ 17

3.3 Nuorten mielenterveyden hoito- ja kuntoutusinterventioita................ 18

$4 \quad$ Tavoitteet osana ihmisen elämää............................................................. 21

4.1 Sosiokognitiivinen teoria.......................................................... 21

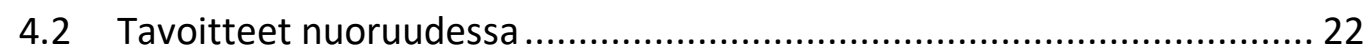

4.3 Tavoitteet kuntoutumisessa ..................................................... 23

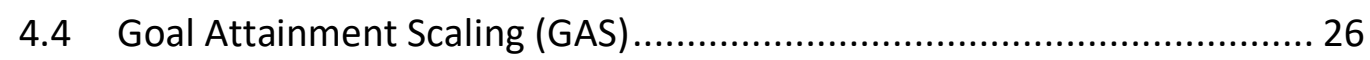

$5 \quad$ Opinnäytetyön tarkoitus ja tavoitteet........................................................... 27

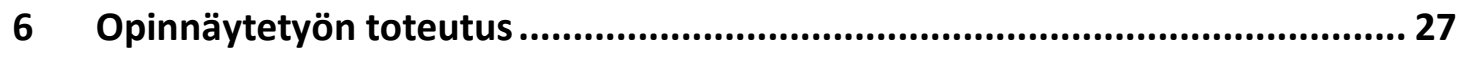

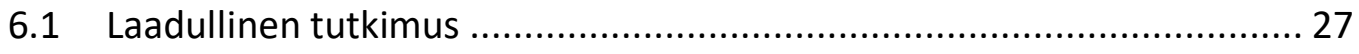

6.2 Tutkimuksen aineisto ja aineiston keruu ....................................... 28

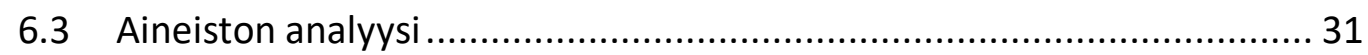

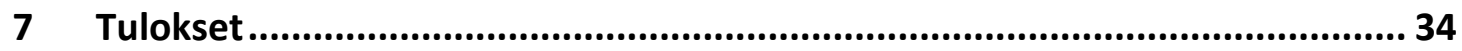

7.1 Ikätasoiset toiminnalliset roolit...................................................... 35

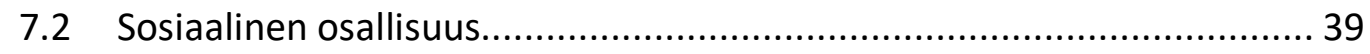

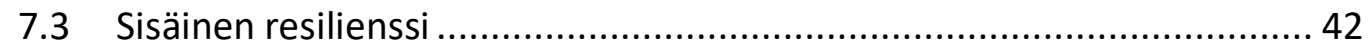


8 Pohdinta

8.1 Tulosten tarkastelu 48

8.2 Tutkimuksen eettisyys 52

8.3 Tutkimuksen luotettavuus 54

8.4 Johtopäätökset 56

Lähteet 58

Liitteet 68

\section{Taulukot}

Liite 1. Taulukko 1 Ikätasoiset. toiminnalliset roolit pääkatagorian muodostuminen ................68

Liite 2. Taulukko 2. Sosiaalinen osallisuus pääkategorian muodostuminen...............................70

Liite 3. Taulukko 3. Sisäinen resilienssi pääkategorian muodostuminen ...................................71

\section{Kuviot}

Kuvio 1. ICF-luokituksen osa-alueiden vuorovaikutussuhteet (kuvio Toimintakyky ICF -luokituksessa 2016) 9

Kuvio 2. Tutkittavien valikoituminen tutkimukseen..............................................................................30

Kuvio 3. Pääkategoria Ikätasoiset toiminnalliset roolit ................................................................35

Kuvio 4. Toimintakykyyn liittyvien tavoitteiden ryhmä ja alaryhmät .............................................37

Kuvio 5. Käyttäytymisen hallintaan liittyvien tavoitteiden ryhmä ja alaryhmät................................38

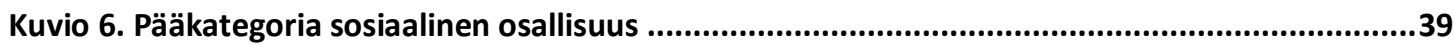

Kuvio 7.Työelämään ja opiskeluun liittyvien tavoitteiden ryhmä ja alaryhmät ................................41

Kuvio 8. Pääkategoria Sisäinen resilienssi.........................................................................42

Kuvio 9.Psyykkiseen terveydentilaan liittyvien tavoitteiden ryhmä ja alaryhmät ...........................44

Kuvio 10. Valtaistumiseen liittyvien tavoitteiden ryhmä ja alaryhmät ........................................45

Kuvio 11. Fyysisen terveydentilan edistämiseen liittyvien tavoitteiden ryhmä ja alaryhmät ............46

Kuvio 12. Tunnesäätelytaitoihin liittyvien tavoitteiden ryhmä ja alaryhmät..................................47 


\section{Johdanto}

Nuorten syrjäytymiseen liittyvässä kansallisessa keskustelussa mielenterveydenongelmat ja häiriöt on nostettu esiin yhtenä selittävistä tekijöistä syrjäytymiskehityksen takana (ks. Aaltonen, Berg \& Ikäheimo 2015, 2; Kestilä, Heino \& Solantaus 2011). Viimeisimpien rekisteritietojen perusteella vuonna 2015 Suomessa jäi mielenterveyssyistä työkyvyttömyyseläkkeelle 2289 alle 35-vuotiasta henkilöä (Joensuu \& Holappa 2017). Tilastokeskuksen mukaan tämä on 0,17 prosenttia Suomen 15-34vuotiaista vuoden 2017 lopussa (ks. Suomen virallinen tilasto 18.6.2018). Kansaneläkelaitos (tästä eteenpäin Kela) on tukenut nuorten opiskelua aiempaa enemmän, mutta se ei välttämättä ole johtanut työllistymiseen. Yli puolet kuntoutusrahaa saaneista nuorista on siirtynyt työkyvyttömyyseläkkeelle etuuden saamista seuranneiden seuraavan viiden vuoden aikana. (Koskenvuo 2017.)

Mielenterveyden häiriöt voivat ilman asianmukaista hoitoa ja kuntoutusta aiheuttaa inhimillistä kärsimystä, sosiaalista syrjäytymistä ja yhteiskunnallisia kustannuksia. Erityisesti vaikeat psykiatriset sairaudet kuten psykoosi, kaksisuuntainen mielialahäiriö ja vaikea masennus laskevat toimintakykyä. (Gee, Notley, Byrne, Clarke, Hodgekins, French \& Fowler 2016, 1; Whiteford, Degenhardt, Rehm, Baxter, Ferrari, Erskine, Charlson, Norman, Falxman, Johns, Burstein, Murray \& Vos 2013, 1579-1583.) Tuoreen meta-analyysin mukaan vain yksi seitsemästä ensipsykoosiin sairastuneesta toipuu huolimatta saadusta hoidosta (Morin \& Franck 2017, 1). Vakavissa psykiatrisissa sairauksissa nuoren kehitys hidastuu ja jumiutuu (Aalto-Setälä \& Marttunen 2007, 210-211). Viime vuosina on kehitetty uudenlaisia hoito- ja kuntoutusmuotoja vaikeisiin mielenterveydenhäiriöihin (ks. Tan, Ng, Sudhasan, Chng, Mok \& Lee 2018; RAISE Questons and Answers 2017; Gee ym. 2016; Viertiö, Mehtälä \& Sailas 2016; Leppänen 2015; Jormfeldt, Svensson, Hansson \& Svedberg 2014).

Tavoitteiden asettelu on yksi keskeisistä mielenterveyskuntoutuksen osa-alueista, koska se on yhteydessä kuntoutusmotivaatioon ja yksilön elämänlaatuun (Shamidi, Gelkopf, Garber-Epstein, Baloush-Kleinman, Dudai, Scialom \& Roe 2017, 1314). Suomalaisen tutkimuksen mukaan eri-ikäisten ihmisten tavoitteet heijastelevat ikätasolle kuuluvia kehitystehtäviä (Nurmi 1992, 487-508). Myös kuntoutuksen tavoitteiden tulisi tukea laajemmin yksilön elämän tavoitteita ja kehitystehtäviä, 
jolloin ne voivat motivoida paremmin osallistumaan kuntoutukseen (Martin 2016, 197; Eklund \& Tjörnstrand 2013, 441-442; Nair 2011, 192, 197-200; Toivonen 2010, 23). Suomessa on viime vuosina tutkittu esimerkiksi lääkinnällistä kuntoutusta saaneiden nuorten tavoitteita (Martin 2016, 17) ja kuntoutuksen tavoitteiden asettelua ja saavuttamista sairaalaympäristössä (Alanko, Karhula, Piirainen, Kröger \& Nikander 2017, 4; Autere, Paavola, Selander \& Kilkku 2009, 24-25).

Suomalaisessa yhteiskunnallisessa keskustelussa on todettu, että tarvitaan lisää kuntoutukseen liittyvää kustannus-hyöty- sekä vaikuttavuustutkimusta (Kuntoutuksen uudistamiskomitea 2017, 18; Toivonen 2010, 22). Tutkimusta tarvittaisiin lisää myös tehokkaista psykiatristen palveluiden toimintamalleista (Whiteford ym. 2013, 1583). Tähän liittyen on tärkeä huomioida kuntoutujan omien tavoitteiden ja niiden saavuttamisen merkitystä vaikuttavuuden arvioinnissa (Toivonen 2010, 22-23). Nämä tulisi huomioida erityisesti siksi, koska tavoitteiden asettelun rooli mielenterveyskuntoutuksessa on keskeinen (Shamidi ym. 2017, 1314; Martin 2016, 197; Eklund \& Tjörnstrand 2013, 441-442; Silverman Nair 2003, 192, 197-200; Toivonen 2010, 23).

Tämä opinnäytetyö on toteutettu osana tutkimushanketta "Psykiatrisen kuntoutuksen vaikuttavuus-Retrospektiivinen tutkimus Sähäkässä vuosina 2011-2016 kuntoutuksessa olleiden nuorten kuntoutusprosessin vaikuttavuudesta". Tutkimushanke toteutuu yhteistyössä Oulun yliopiston, Pohjois-Pohjanmaan sairaanhoitopiirin ja Coronaria Sähäkkä Oy:n kanssa. Tämän opinnäytetyön aineisto muodostui nuorten mielenterveyskuntoutujien asumiskuntoutuksessa kerätyistä rekisteritiedoista, joita tarkasteltiin retrospektiivisesti laadullisin menetelmin. Opinnäytetyön tarkoituksena oli lisätä ymmärrystä tavoitteista nuorten mielenterveyskuntoutuksessa. Tutkimuksen tulosten avulla voidaan kehittää mielenterveyskuntoutuksen tavoitteiden asettelua. Tavoitteena oli nuorten kuntoutukselle asettamien tavoitteiden tarkasteleminen ja kuvaileminen. 


\section{Mielenterveyskuntoutus}

\subsection{Kuntoutus ja ICF-viitekehys}

Kuntoutuksen käsite on määritelty pyrkimykseksi ylläpitää ja kohentaa yksilön psyykkistä, fyysistä ja sosiaalista toimintakykyä. Kuntoutuksella on myös tarkoitettu toimia, joilla edistään ja tuetaan yksilön elämänhallintaa ja itsenäistä suoriutumista päivittäisistä toiminnoista. Keskeistä on, että tarpeen kuntoutukselle on nähty syntyvän sairauden tai vamman vuoksi. Kuntoutuksen on ajateltu koostuvan lääkinnällisistä, kasvatuksellisista, sosiaalisista ja ammatillisista palveluista. (Järvikoski 2013,42 .) Viime vuosien yhteiskunnallisessa keskustelussa on korostettu kuntoutuksen laaja-alaisuutta ja prosessinomaisuutta (Kuntoutuksen uudistamiskomitea 2017, 40). Prosessin aikana moniammatillinen työryhmä pyrkii ratkaisemaan kuntoutujan haasteita yhdessä hänen kanssaan (Bovend'Eerd, Botell, \& Wade 2009, 352). Yksilö nähdään kuntoutuksen toimijana ja tavoitteiden asettajana. Myös ympäristö on toimintakykyyn vaikuttava osa-alue, joka tulee huomioida kuntoutuksessa. (Kuntoutuksen uudistamiskomitea 2017, 40.)

Worralin (2005) mukaan kuntoutuksen yleiseksi viitekehykseksi voisi sopia Toimintakyvyn, toimintarajoitteiden ja terveyden käsitteellinen malli (International Classification of Functioning, jatkossa ICF-viitekehys). Sen avulla voitaisiin selittää kuntoutumiseen johtaneita tekijöitä sekä kuntoutuspolkuja. (Koukkari, 2010, 40; Järvikoski 2008, 54.) Myös kuntoutuksen uudistamiskomitea $(2017,46)$ on linjannut, että ICF-viitekehystä tulisi käyttää Suomessa kuntoutuksen toimintakyvynarvioinnin perustana. ICF-viitekehyksen taustalla on biopsykososiaalinen malli ja se kuvaa, miten sairaus tai vamma näkyy ihmisen elämässä. Viitekehys kuvaa toimintakykyä ja rajoitteita vuorovaikutuksellisena, moniuloitteisena ja dynaamisena tilana, jonka osia ovat terveydentila, yksilö ja ympäristö. Tavoitteena ICF-viitekehyksen käytössä ovat yhteinen kieli ammattilaisten kesken sekä tieteellinen perusta toimintakyvyn tutkimukselle ja kuvaukselle. (ICF-luokitus 2016.)

ICF -luokitus jakautuu kahteen osaan. Ensimmäinen osa kuvaa toimintakykyä ja rajoitteita. Toinen osa kuvaa ympäristö- ja yksilötekijöitä. Toimintakyvyn ja rajoitteiden osio jakautuu edelleen kehon toimintoihin, rakenteisiin sekä 
suoritukseen ja osallistumiseen. Käytännön työn kannalta ICF-viitekehyksen voi ymmärtää esimerkiksi katsomalla kuviota 1., jossa on kuvattu eri toimintakyvyn osaalueiden suhdetta toisiinsa ja niiden vuorovaikutuksellisuutta (ICF-luokitus 2016.) Järvikosken (2008) mukaan viitekehystä voitaisiin edelleen täydentää kokemuksellisella ulottuvuudella, jolloin ulkopuolisen asiantuntijan tekemän arvion lisäksi viitekehykseen lisättäisiin yksilön oma kokemus tilanteesta ja prosessista. Kuntoutuksen kannalta keskeisimmiksi käsitteiksi nousevat suoritukset ja osallistuminen. (Järvikoski 2008, 51.)

\section{ICF-luokituksen osa-alueiden vuorovaikutussuhteet}

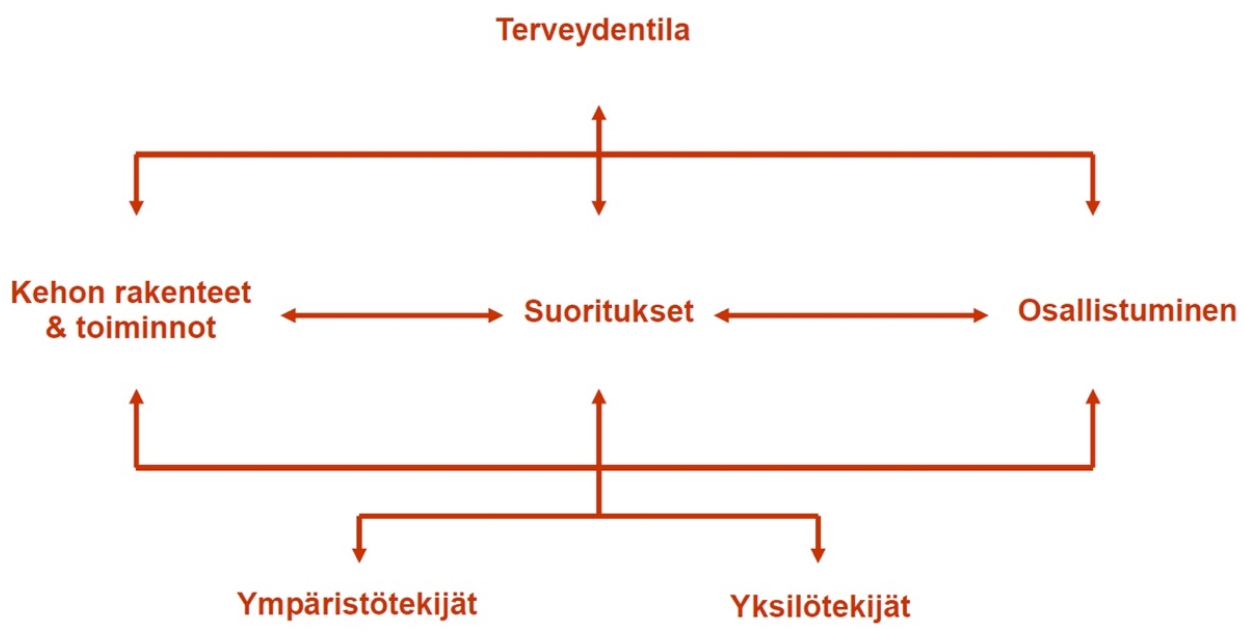

Kuvio 1. ICF-luokituksen osa-alueiden vuorovaikutussuhteet (kuvio Toimintakyky ICFluokituksessa 2016)

\subsection{Mielenterveyskuntoutus}

Psykiatristen sairaaloiden vuodenpaikkoja on vähennetty 1990-luvulta saakka (Aulanko \& Hellman 2017, 361). Tämä muutos on synnyttänyt tarpeen psykiatriselle kuntoutukselle. Psyykkisiä sairauksia sairastaville henkilöille on tullut mahdolliseksi 
ja tarpeelliseksi selvitä itsenäisessä asumisessa yhteisöissä. Psykiatrisen kuntoutuksen tarkoituksena on auttaa yksilöä valitsemaan tavoitteensa, hankkimaan niiden saavuttamiseen tarvittavat taidot ja tuki, jotta tavoitteiden saavuttaminen on mahdollista. (Anthony \& Farkas 2009, 7-10.) Järvikoski (2013, 51-52) määrittelee psykiatrisen kuntoutuksen käsitteen aiemmin käytetyksi termiksi, jolla on tarkoitettu lääkärin diagnosoimien psykiatristen sairauksien kuntoutusta.

2000-luvulla Suomessa on alettu suosia käsitettä mielenterveyskuntoutus, jolla on tarkoitettu ennemmin monenlaisissa elämäntilanteissa olevien yksilöiden kuntoutusta, jota on voinut olla myös ilman diagnosoitua psykiatrista sairautta. Hoidon ja kuntoutuksen välisen rajan määrittäminen on mielenterveyden häiriöissä erityisen hankalaa. Mielenterveyskuntoutuksen käsite pitääkin sisällään perinteisen toimintakyvyn kuntoutuksen lisäksi esimerkiksi ammatillista ja sosiaalista kuntoutusta. (Järvikoski 2013, 51-52.) Pylkkäsen $(2008,167)$ mukaan käsite voi kuitenkin olla liian laaja kuvaamaan erityisesti vaikeiden mielenterveyden häiriöiden kuntoutusta.

Kuntoutuminen koostuu kolmesta ulottuvuudesta: oppimisesta, muutoksesta ja kasvusta. Kuntoutuksen ytimessä on yksilö toimivana ja tahtovana tekijänä omassa elämässään ja suhteessa kuntoutuksen menetelmiin ja käytänteisiin. Kuntoutuksen tuloksellisuutta määrittävät kuntoutujan kuntoutusmotivaatio ja myönteinen asenne. Kuntoutumista edistäviä tekijöitä ovat myös henkilökohtaiset tavoitteet ja toiminta niitä kohti, onnistumisen kokemukset, valmiudet itsenäiseen selviytymiseen ja lähiympäristön odotukset. (Koukkari 2010, 28, 34, 169.) Nykyisessä kuntoutusajattelussa kuntoutuja on autonominen ja aktiivinen toimija, joka itse asettaa omat tavoitteensa kuntoutustoiminnalle. Tavoiteltavat merkitykselliset asiat ja toiminta niitä kohti ovat kuntoutuksessa keskiössä. (Järvikoski, Härkäpää \& Salminen 2015, 18, 22.) On mahdotonta määrittää, mitä kuntoutuminen on yksilölle tai mikä on hyvä lopputulema, koska jokainen määrittelee sen itse (Henderson \& Jackson 2017, 13; Jorgensen \& Rendtorff 2017, 499-500). Tan ja muut (2018) ovat todenneet, että toimintaterapeuttisessa kuntoutuksessa mielenterveyskuntoutujille parempi kuntoutuminen oli merkitsevässä yhteydessä parempaan päivittäiseen selviytymiseen yhteisössä. Psykologinen hyvinvointi ja toipuminen voidaan myös 
yhdistää elämäntyytyväisyyteen. (Browne, Penn, Meyr-Kalos, Mueser, Estroff, Brunette, Correll, Robinson, Rosenheck, Schooler, Robinson, Addington, Marcy \& Kane 2017, 170-172).

Kuntoutumisen lähikäsitteitä ovat valtaistuminen, voimaantuminen ja elämänhallinta. Valtaistumisella tarkoitetaan sitä, että yksilö näkee itsensä aktiivisena toimijana, jolla on mahdollisuus vaikuttaa omaan elämäänsä ja muiden ihmisten elämään. Valtaistuminen on positiivinen käsite, jolla voidaan kuvata kuntoutuksen tavoitetta. (Järvikoski 2013, 39-40; Koukkari 2010, 21; World Health Organization 1998, 6). Valtaistuminen voi olla kulttuurista, sosiaalista, psykologista tai poliittista. Sen avulla yksilö tai yhteisö voi ilmaista tarpeensa, huolensa, osallistua päätöksentekoon ja saavuttaa asettamiaan tavoitteita. Valtaistumisen prosessin avulla yksilöllä on parempi yhteys tavoitteidensa ja niiden saavuttamisen välillä ja toisaalta yrittämiensä ja saavuttamiensa lopputulemien välillä. (World Health Organization 1998,6 .) Autonomian käsite on keskeinen puhuttaessa valtaistumisesta: ihmisellä on oltava itsemääräämisoikeus omaa elämäänsä koskeviin asioihin. (Koukkari 2010, 21; World Health Oraganization 1998, 6).

Positiivinen mielenterveys on keskeinen osa hyvinvointia ja terveyttä (Positiivinen mielenterveys 2018), ja siksi tärkeä huomioida mielenterveyskuntoutuksessa. Terveyden ja hyvinvoinnin laitoksen (2018) mukaan positiiviselle mielenterveydelle on useita määritelmiä. Yhteistä niille on, että tarkoitetaan psyykkisiä voimavaroja, vaikuttamismahdollisuuksia omaan elämään, elämänhallintaa ja toiveikkuutta, tyydyttäviä sosiaalisia suhteita ja myönteistä käsitystä itsestä. (Positiivinen mielenterveys 2018) Suomalaisen tutkimuksen mukaan 10-24 vuoden seuranta-ajalla osalla nuorista ja lapsista positiivinen mielenterveys lisääntyi ja osalla suhteellisesti heikentyi (Sourander \& Marttunen 2016, 121-122).

Resilienssin käsite on yksi positiiviseen mielenterveyteen liittyvistä käsitteistä (Dray, Bowman, Freund, Campbell, Wolfenden, Hodder \& Wiggers 2014, 2). Resilienssi on psykologinen dynaaminen prosessi, jonka avulla yksilö pyrkii hyvinvointiin (Ungar, Ghazinour \& Richter 2013, 349). Resilienssi on yksilön kykyä stressaavissa ja vaikeissa tilanteissa aktiivisesti käyttää henkilökohtaisia ominaisuuksia ja ympäristöä hyväksi positiivisen mielenterveyden säilyttämiseksi. Ensin mainittuja kutsutaan sisäisiksi re- 
silienssitekijöiksi, joihin kuuluvat esimerkiksi minäpystyvyys ja ongelmanratkaisutaidot. Ulkoisiin resilienssitekijöihin lasketaan kuuluvaksi mielekäs opiskelu tai työ, koti ja yhteiskunnallinen osallistuminen sekä ikätasoiset vuorovaikutussuhteet. (Dray ym. 2014, 2.) Ihmiset hyödyntävät erityisesti kohdatessaan haasteita sekä sisäisiä- että ulkoisia resilienssitekijöitä. Nuorten resilienssin kohentumiseen voidaan kuitenkin vaikuttaa tehokkaimmin lisäämällä yksilön ulkoisia resilienssitekijöitä. (Ungar ym. 2013, 360.)

2010-luvulla suomalaisessa yhteiskunnassa keskeisenä tavoitteena on nähty kansalaisten osallisuus (Isola, Kaartinen, Leemann, Lääperi, Schneider, Valtari \& Keto-Tokoi 2017, 3). Osallisuuden lisäämiseen on pyritty vaikuttamaan muun muassa erilaisin hankkein. Esimerkkejä hankkeista ovat Sosiaali- ja terveydenhuollon kansallinen kehittämisohjelma KASTE II 2012-2015 (Sosiaali- ja terveysministeriö 2016, 6) sekä Sosiaalisen kuntoutuksen kehittämishanke SOSKU 2015-2018 (Raivio 2018, 3). Osallisuudella tarkoitetaan suhteissa olemista, niihin liittymistä, kuulumista, yhteisyyttä, yhteensopivuutta ja mukaan ottamista. Lisäksi osallisuutta tukee hallinnollinen prosessi, jolla johdetaan kansalaisten mahdollisuutta osallisuuteen. (Isola ym. 2017, 3.)

Osallisuus voidaan ymmärtää suhteena elämän merkityksellisyyttä lisääviin vuorovaikutussuhteisiin sekä kuulumisena kokonaisuuteen kuten yhteiskunta, joka mahdollistaa pääsyn aineellisiin ja aineettomiin hyvinvoinnin lähteisiin. Osallisuus on ihmisten eleissä, ilmeissä sekä kielessä, joten sen mittaaminen on haastavaa. Osallisena omasta elämästään henkilön on mahdollista vaikuttaa yhteisiin asioihin, kuten yhteisön toimintoihin, palveluihin sekä oman elämänsä mahdollisuuksiin ja kulkuun. Yksilön tavoitteellinen toimijuus on mahdollinen, kun hän voi olla sosiaalisesti osallisena. (Isola ym. 2017, 3.)

Sosiaalisen osallisuuden voidaan nähdä olevan nelitasoista. Tasoja ovat taloudellinen mahdollisuus osallistua ja hallinnolliset suhteet, kuten työntekijän ja työnantajan välinen suhde. Muita tasoja ovat yhteisiin kiinnostuksen kohteisiin liittyvät suhteet, kuten harrastusryhmät sekä vuorovaikutussuhteet, kuten perhe ja ystävyyssuhteet. (Reimer 2004, 78-81.) Sosiaalisen osallisuuden käsitteen lähikäsitteenä voidaan ajatella olevan toiminnallisten roolien käsite. Mielenterveyskuntoutuksen yhtenä tavoitteena on, että ihminen kykenee toimimaan ikätasoisten toiminnallisten rooliensa 
mukaisesti, esimerkiksi opiskelijana, kumppanina ja ystävänä. (Anthony \& Farkas 2009, 9-10.)

\subsection{Mielenterveyskuntoutuksen interventiot tutkimuksen kohteena}

Viime vuosina on sekä Suomessa että kansainvälisesti kehitetty uudentyyppisiä hoitoja kuntoutusinterventioita nimenomaan vaikeisiin mielenterveyden häiriöihin. Alla esitellään tällä hetkellä keskeisiä interventiota ja tutkimustuloksia niihin liittyen, kuten laaja-alaisia kuntoutusohjelmia (RAISE Questons and Answers 2017; Gee ym. 2016; Leppänen 2015; Jormfeldt ym. 2014), toimintaterapiaa hyödyntäviä ohjelmia (Tan ym. 2018; Lindström, Sjöström \& Lindberg 2013, 730; Schindler 2009, 105) sekä kognitiivisen kuntoutuksen erilaisia lähestymistapoja (Viertiö ym. 2016).

Morin ja Franck (2017) ovat nostaneet systemaattisessa katsauksessaan esille kaksi ehdotusta skitsofreniasta toipumista edistävän kuntoutuksen suhteen. Ensimmäinen ehdotus oli laaja-alainen yksilön toiminnallisen tilanteen arviointi, joka huomioi esimerkiksi kognition, toimintakyvyn ja ympäristötekijät. Arvioinnin perusteella tulisi tehdä yksilöllinen kuntoutumissuunnitelma ja asettaa tavoitteita yhdessä kuntoutujan kanssa. Toisena ehdotuksena oli yksilölle sopiva kuntoutus, jolla vaikutetaan kognitioon sekä psykoosisairauden vetäytymistä ja mielialan laskua aiheuttaviin oireisiin. (Morin \& Franck 2017, 2.) Suomalaisessa Käypä hoito -suosituksessa mainitaan skitsofreniaa sairastavan henkilön tarvitsevan kokonaisvaltaista kuntoutusta. Kuntoutuksessa voidaan hyödyntää esimerkiksi psykoedukaatiota eli sairaudesta ja sen oireista opettamista yksilölle ja hänen läheisilleen, vertaistukea, ryhmämuotoisia interventioita, sosiaalisten ja arjen taitojen harjoittelua sekä kognitiivista kuntoutusta. (Skitsofrenia. Käypä hoito -suositus 2013, 16-19.)

Boston Psychiatric Rehabilitation-mallia on käytetty ja tutkittu Yhdysvaltojen lisäksi esimerkiksi Pohjoismaissa. Malli soveltuu erilaisten mielenterveyden häiriöiden kuntoutukseen. Mallin perusajatuksena on yhteinen tavoitteiden asettelu ja kuntoutuksen suunnitelu asiakkaan ja ammattilaisen välillä. Mallissa korostetaan tavoitteiden asettelua arviointivaiheessa, mutta myös läpi prosessin. (Jormfeldt ym. 2014.) 
Boston Psychiatric Rehabilitation-mallin toimivuudesta on todettu, että sillä ei ole vaikutusta kuntoutujien asumiseen tarvittavaan tukeen, mutta se lisää työllistymistä avoimille ja tuetuille työmarkkinoille (Svedberg, Svensson, Hansson \& Jormferldt 2014, 404; Swildens, van Busschbach, Michon, Kroon, Koeter, Wiersma \& van Os 2011, 757-759) sekä koulutukseen osallistumista (Swildens ym. 2011, 758). Viimeksi mainitut ovat sosiaalisen osallisuuden osa-alueita ja onkin todettu myös, että mallin mukaiseen kuntoutukseen osallistuneet saavuttivat useammin sosiaalisiin suhteisiin liittyvät tavoitteensa (Swildens ym. 2011, 758). Mallia hyödyntävään kuntoutukseen osallistuneiden henkilöiden valtaistuminen oli kohentunut (Svedberg ym. 2014, 404). Sen sijaan vertailtaessa malliin perustuvaa kuntoutusta muihin hoitomuotoihin on osallistujien elämänlaatu kohentunut yhtälailla molemmissa interventioissa (Swildens ym. 2011, 758-759).

NIMH RAISE-ETP-hankkeessa on kehitetty ja tutkittu uusia ensipsykoosin hoito- ja kuntoutusmenetelmiä (RAISE Questons and Answers 2017). NAVIGATEterapiaohjelma perustuu toipumismalleihin, jotka eivät korosta oireiden poistumista. Terapiaohjelmassa hyödynnetään lääkehoitoa, perheen psykoedukaatiota, resilienssin vahvistamisinterventioita, tuettua työllistymistä sekä opiskelua. NAVIGATE-terapiaohjelmasta tehdyssä seurantatutkimuksessa on todettu, että kahden vuoden aikana psykologinen hyvinvointi ja toipuminen etenivät sekä terapiaryhmään osallistuneilla että verrokkiryhmällä, joka sai yhteisöhoitoa. (Browne ym. 2017, 168, 171.) Psykoosipotilaiden yhteisöhoidosta on todettu, että sen avulla osallistujien suhtautuminen lääkitykseen on ollut positiivisempaa, itsetunto on kohentunut ja sosiaalisissa suhteissa on tapahtunut positiivisia muutoksia. Elämäntyytyväisyys oli myös lisääntynyt. (Mayer, Petrovic, Grah, Loveretic \& Filipcic 2017, 447-450.)

Psykoosisairauksiin alettiin kehittämään kognitiivisia hoito- ja kuntoutusmenetelmiä 1960-luvulla. Nykymuodossaan ne yhdistävät myös sosiaalisen kognition osa-alueita (Viertiö ym. 2016, 632-633) ja ammatillista kuntoutusta (Bowie, Crossman, Gupta, Holshausen \& Best 2017, 53-60). Systemaattisen katsauksen mukaan kognitiivisilla kuntoutusmentelmillä oli positiiivista vaikutusta psykoosia sairastavien kognitioon. Kognitiivisten kuntoutusmenetelmien vaikutuksista sosiaalisten taitojen kohentumiseen on heikkoa näyttöä. Parhaat tulokset saadaan harjoitusohjelmilla, 
jotka ovat laaja-alaisia. Tälläisia ovat harjoitusohjelmat, joissa haastavuus lisääntyy vähitellen ja ohjelma perustuu virheettömään oppimiseen sekä intensiiviseen ohjaukseen. (Rodriguez-Blanco, Lubrini, Vidal-Marino, Rios-Lago 2017,169-176.) Kognitiviinen kuntoutus oli merkittävästi tehokkaampaa yhdistettynä päivittäisten toimintojen ja sosiaalisten taitojen harjoitteluun, psykoedukaatioon ja ammatilliseen kuntoutukseen (Morin \& Franck 2017, 5). Suomessa on käynnissä MATTI-projekti, jossa tuetaan mieleterveyskuntoutujien asumista. Tämä malli perustuu kognitiiviseen adaptaatioon. Käytännössä tällä tarkoitetaan ympäristön mukauttamista esimerkiksi apuvälineiden avulla. (Viertiö ym. 2016, 635-636.)

Suomalainen Käypä hoito -suositus suosittelee epävakaan persoonallisuushäiriön hoidossa ja kuntoutuksessa käytettäväksi lyhyitä määräaikaisia psykoterapioita, erityisesti kognitiivista käyttäytymisterapiaa, dialektista käyttäytymisterapiaa tai skeematerapiaa. Päiväsairaalamuotoinen psykoterapeuttinen interventio voi myös olla tehokas epävakaan persoonallisuushäiriön kuntoutuksessa. (Epävakaa persoonallisuus. Käypä hoito -suositus 2015, 15-17.) Leppäsen (2015) tekemän väitöstutkimuksen mukaan dialektista käyttäytymisterapiaa ja skeematerapiaa yhdistävä hoitomalli tehostaa epävakaan persoonallisuushäiriön hoitoa perusterveydenhuollossa. Hoitomallissa hyödynnetään myös psykoedukaatiota. Hoitomallin mukaisella hoidolla pystyttiin vähentämään vaikeimpia oireita, kuten itsetuhoisuutta ja impulsiivisuutta. Tutkimuksessa todettiin, että potilaat sitoutuivat paremmin tiiviiseen, sisällöltään ja ajankäytöltään ennalta suunniteltuun hoitoon. (Leppänen 2015, 73-76, 112-117.)

Sosiaalisten tilanteiden pelon kuntoutuksessa on hyödynnetty erilaisia psykoterapeuttisia suuntauksia ryhmä- ja yksilötyöskentelyssä, esimerkiksi kognitiivista käyttäytymisterapiaa (Nolen-Hoeksema, Fredrickson, Loftus \& Lutz 2014, 541-545), mindfullnessia sekä hyväksymis- ja omistautumisterapeuttisia lähestymistapoja (Norton, Abbott, Norberg, \& Hunt 2015, 283). Systemaattisessa katsauksessa on todettu, että vaikka hyväksymis- ja omistautumisterapeuttiset lähestymistavat vähentävätkin merkittävästi sosiaalisten tilanteiden pelon oireita, on kognitiivis-käyttäytymisterapeuttinen lähestymistapa tehokkaampi (Norton ym. 2015, 295). 
Amerikan psykologiliiton suosituksen mukaan altistamiseen perustuvat terapiamuodot ovat suositeltavia käytettäviksi ahdistuneisuushäiriöiden hoidossa (Carl, Stein, Levihn-Coon, Pogue, Rothbaum, Emmalkamp, Asmundson, Carlbring \& Powers in press). Tutkimuksissa sosiaalisten tilanteiden pelon kuntoutuksesta onkin useimmiten käytetty menetelmänä kognitiiviseen käyttäytymisterapiaan perustuvaa altistamista ahdistaville tilanteille. Pienillä koeasetelmilla on tutkittu menetelmää myös virtuaalisin keinoin toteutettuna. (Freeman, Reeve, Robinson, Ehlers, Clark, Spanlang \& Slater 2017, 1393; McCann, Armstrong, Skopp, Edwards-Stewart, Smolenski, June, Metzger-Abamukong \& Reger 2014, 625.)

Useissa päivittäisen toimintakyvyn kohentamiseen tähtäävissä mielenterveyden häiriöiden kuntoutusohjelmissa hyödynnetään toimintaterapiaa (Tan ym. 2018; Lindström ym. 2013, 730; Schindler 2009, 105). Joillakin interventioilla pyritään vaikuttamaan yksilön kaikkiin toimintakokonaisuuksiin (Tan ym. 2018). Toisissa kuntoutusohjelmissa taas pyritään mielekkäämpään arkeen ja asumiseen kotikuntoutuksen keinoin (Lindström ym. 2013) ja toisissa tähdätään työllistymiseen (Schindler \& Sauerwald 2009, 105). Kuntoutusohjelmassa, jossa tavoitteena oli mielenterveyskuntoutujien työllistyminen, oli yhdistetty toimintaterapiaa ja tuettua opiskelua tai työtä. Kuntoutusohjelma oli mahdollistanut kuntoutujien etenemisen tavoitteitaan kohti pääosassa tavoitealueita. Kuntoutujat olivat myös tyytyväisempiä toimintakykyynsä kuin lähtötilanteessa. (Schindler \& Sauerwald 2009, 105-111.)

\section{Mielenterveyskuntoutus nuoruusiässä}

\subsection{Nuoruusikä}

Kirjallisuudesta voi löytää useita määritelmiä siitä, mikä ikävaihe ihmisen elämää lasketaan nuoruudeksi. Varhaisnuoruudessa noin 11-14-vuotiaana nuoren tulisi kyetä sopeutumaan muuttuneeseen kehoonsa ja seksuaalisuuteensa. Tuossa iässä alkaa myös irtautuminen vanhemmista ja kiinnittyminen ystävyyssuhteisiin. Keskinuoruu- 
dessa noin 15-18-vuotiaana nuori pohtii, kuka hän on ja millainen on oma osaaminen, taidot, sosiaaliset suhteet sekä mahdolliset parisuhteet. Myöhäisnuoruus alkaa 18 ikävuoden jälkeen, jolloin korostuvat kysymykset koulutuksesta, ammatinvalinnasta, moraalista ja arvomaailmasta. Lisäksi muodostetaan vakaampia parisuhteita ja irtaannutaan lopullisesti vanhemmista. (Aalto-Setälä \& Marttunen 2007, 207-208.) Nuoruudessa tulisi ikään kuin löytää vastaus kysymykseen omasta identiteetistä. Tuo vastaus olisi optimaalista löytää 20-25-ikävuoden välissä. (Noelen-Hoeksema ym. 2014, 95.)

Teollistuneiden maiden sosiaaliset ja taloudelliset muutokset edeltävinä vuosikymmeninä ovat siirtäneet aikuisuuteen siirtymistä. Tätä ilmiötä on kuvattu termillä emerging adulthood, joka voidaan suomentaa muotoutuva aikuisuus. Vaihe voi kestää 19 vuodesta jopa 30 ikävuoteen. Tuona aikana nuoret voivat tutustua erilaisiin mahdollisuuksiin työn, ihmissuhteiden ja maailmankuvan osalta. Tälle vaiheelle on edelleen ominaista identiteetin etsintä. Kokemusten mukaan aikuisuuden saavuttamisessa keskeisiä asioita ovat vastuun ottaminen itsestä, itsenäisten päätösten tekemisen kyky sekä taloudellinen itsenäisyys. (Arnett 2000, 469-478.) Tästä ajanjaksosta on käytetty myös termejä varhaisaikuisuus ja myöhäisnuoruus. (Nurmi, Ahonen, Lyytinen, Lyytinen, Pulkkinen \& Ruoppila 2014, 143, 178-179.)

\subsection{Mielenterveydenhäiriöt nuoruudessa}

Suomessa vuonna 2003 nuoruusiän mielenterveydenongelmien esiintyvyys on ollut 20-30 \% ikäluokasta. Vakavia häiriöitä, jotka vaikuttavat toimintakykyyn ja vaativat hoitoa on noin kymmenellä prosentilla ikäluokasta. (Hoitotakuu nuorisopsykiatriassa NUOTTA -projektin loppuraportti 2003 2003, 35.) Kansainvälisesti vuonna 2011 lasten ja nuorten mielenterveysongelmien esiintyvyys on ollut 10-20 \% ikäluokasta (Kieling, Baker-Henningham, Belfer, Conti \& Ertem 2011, 1515). Suurin osa vakavista psykiatrisista sairauksista alkaa ennen 25 vuoden ikää (Gee ym. 2016, 1), tyypillisin häiriöiden alkamisikä on 16 vuotta (Hoitotakuu nuorisopsykiatriassa NUOTTA -projektin loppuraportti 2003 2003, 35). 
Suomessa tyypillisiä mielenterveyden häiriöitä nuoruudessa ovat masennus (5-10\% nuorista), syömishäiriöt sekä käytöshäiriöt ja päihdehäiriöt (5-10 \% nuorista myöhäisnuoruudessa) (Sourander \& Marttunen 2016, 117). Sekä Suomessa että kansainvälisesti psykoottiset häiriöt alkavat pääosin myöhäisnuoruudessa tai varhaisessa aikuisuudessa (esiintyvyys 1-2 \%) (Landa, Mueser, Wyka, Shreck, Jespersen, Jacobs, Griffin, van der Gaag, Reyna, Beck, Silberswieg \& Walkup 2016, 1; Sourander \& Marttunen 2016, 117). Nuorilla useiden mielenterveyden häiriöiden yhtäaikainen esiintyminen on yleistä (Sourander \& Marttunen 2016, 117). Vakavissa psykiatrisissa sairauksissa nuoren kehitys hidastuu ja jumiutuu (Aalto-Setälä \& Marttunen 2007, 210211). Psykoosisairaudet puolestaan vaikuttavat erityisesti kognitiiviseen ja sosiaaliseen kehitykseen (Landa ym. 2016, 1).

Suomessa hoitoon hakeutuminen lasten ja nuorten psykiatristen oireiden vuoksi on lisääntynyt (Santalahti, Sourander \& Piha 2009, 962-963). Esimerkiksi osastohoidon määrä on lisääntynyt 2000-luvun taitteeseen saakka, mutta tasoittunut sen jälkeen. Sairaalahoidon tarpeeseen voi olla useita syitä: avohoidon riittämättömyys, osastohoidon lisääntynyt saatavuus, oireiden parempi tunnistaminen, ongelmien vaikeutuminen ja/tai sairastavuuden lisääntyminen. Osastohoidon määrän tasaantumisen voi ajatella kertovan tarjonnan ja kysynnän tasapainosta tai siitä, ettei enempää palveluja yksinkertaisesti ole tarjolla. (Tuori, Sohlman, Ekqvist \& Solantaus 2006, 3, 11.)

Palvelujärjestelmässä huomiodaan paremmin lapset ja aikuiset, jolloin nuori voi jäädä ilman nuoruuden ikävaiheeseen perehtynyttä ja osaavaa hoitoa ja kuntoutusta (Sosiaali- ja terveysministeriö 2003, 32; Martin 2016, 164-184, 198-199). Nuoren mielenterveyskuntoutuksen tarve liittyy useimmiten nuoruusiän kehityksen häiriintymiseen. Vaikeuksia voi olla koulutuksessa ja ammatinvalinnassa, sosiaalisessa osallistumisessa tai ihmissuhteissa. (Piha \& Tainio 2016, 686.)

\subsection{Nuorten mielenterveyden hoito- ja kuntoutusinterventioita}

Suomessa nuorten mielenterveyden hoidon ja kuntoutuksen polun voidaan nähdä lähtevän jo kouluterveydenhuollon varhaisesta puuttumisesta (Aalto-Setälä \& 
Marttunen 2007, 212-213; Gyllenberg, Marttunen \& Sourander 2016, 124-125). Suomalaisessa järjestelmässä kasvatus- ja perheneuvolat ovat yksi keskeinen osa mielenterveyden ennaltaehkäisevää hoito- ja kuntoutusjärjestelmää (Kuoppala \& Säkkinen 2013, 1).Perusterveydenhuolto ja erikoissairaanhoito muodostavat polun jatkumon. Vakavat sairauden vaativat yleensä hoitoa erikoissairaanhoidossa jopa tahdosta riippumattomasti. (Aalto-Setälä \& Marttunen 2007, 212-213; Gyllenberg ym. 2016, 124-125.) Yksityisellä ja kolmannella sektorilla on myös roolinsa suomalaisessa palvelujärjestelmässä (Gyllenberg ym. 2016, 125).

Suomessa lasten ja nuorten mielenterveyden häiriöihin on tarjottu Kelan rahoittamia ratkaisuja, kuten avo- ja laitosmuotoisia mielenterveyskursseja (Uusia kursseja mielenterveyskuntoutujille 2017) sekä perhekuntoutusta (Linnakangas, Lehtoranta, Järvikoski \& Suikkanen 2010, 34). Perhekuntoutukseen osallistuneista lapsista ja nuorista yli puolella psyykkinen oireilu väheni kuntoutuksen aikana eikä heillä ollut merkittävää psyykkistä oireilua kuntoutuksen päättyessä. Parempaa tilannetta ennustavia tekijöitä olivat vaikeaksi arvioitu oireilu kuntoutuksen alkuvaiheessa sekä kuntoutuksen pidempi kesto. Positiivinen vaikutus oli myös tiiviimmällä yhteydellä nuoren perheeseen. (Linnakangas ym. 2010, 34-39.) Vanhempien tyytyväisyyttä kuntoutukseen voi lisätä myös kuntoutuksen tavoitteiden asettelu ja seuranta (Jacob, De Fransesco, Deighton, Law, Wolpert \& Edbrooke-Childs 2017, 766).

Kela järjestää Suomessa nuorille myös kuntoutuspsykoterapiaa. Kuntoutuspsykoterapiaa saaneiden nuorten määrä on kasvanut, vuonna 2003 kuntoutuspsykoterapiaa sai 4669 nuorta ja vuonna 20158738 nuorta. (Kelan kuntoutustilasto 2015, 12-13.) Nuorten masennuksen hoidossa käytettävistä psykoterapiasuuntauksista on näyttöä kognitiivisesta terapiasta yksilö- ja ryhmäterapiana sekä interpersonaalisesta terapiasta (Depressio. Käypä hoito suositus 2016,18 .)

2010-luvulla Kela on pyrkinyt luomaan uudenlaisia palveluja nuorille, esimerkiksi OPIkurssit, jotka toteutuvat opiskelun yhteydessä (OPI-kurssit 2016). Kurssien arviointitutkimuksessa todetaan, että osallistujat kokivat elämänlaatunsa, terveydentilansa ja opiskelukykynsä kohentuneen. Kurssille osallistuneista $90 \%$ koki siitä olleen hyötyä. Haasteena nähtiin kursseille ohjautumisen käytänteet. (OPIkuntoutuskursien tutkimus 2018.) Muita tällä hetkellä hankemuotoisia palveluja ovat 
Opiskeluvalmennus (Opiskeluvalmennus-projekti 2016-2020 2018) sekä NUOTTIvalmennuspalvelu (NUOTTI-valmennus 2018).

\section{Englantilaisessa PRODIGY-tutkimushankkeessa tutkitaan}

mielenterveyskuntoutusintervention vaikutuksia nuorilla, joilla on riski sosiaaliseen syrjäytymiseen mielenterveysongelmien vuoksi. Intervention tavoitteena on sosiaalinen toipuminen kognitiivis-käyttäytymisterapeuttisesten menetelmien avulla. Ohjelman keskeisenä elementtinä on ymmärrys yksilön arvoista ja tavoitteista. Nuoret ovat kokeneet intervention lisäävän yhteistä ymmärrystä, antavan työkaluja ja joustavuutta terapiassa. (Gee ym. 2016, 1-4.) Psykoosia sairastavien nuorten kohdalla intervention on todettu yhdeksän kuukauden seuranta-ajalla lisäävän osallistumista toimintakokonaisuuksiin, kuten päivittäisiin toimintoihin ja työhön (Fowler, Hodgekins, French, Marshall, Freemantle, McCrone, Everard, Lavis, Joes, Amos, Singh, Sharma \& Birchwood 2018, 44-49).

Kuntoutuksen suunnittelu on erityisen haasteellista tilanteissa, joissa nuori ei halua ottaa vastuuta ja esimerkiksi suhtautuu kielteisesti kuntoutukseen. Haastavaa voi myös olla huomioida nuoren ja vanhempien suhde, joka voi olla ristiriitainen ja monin tavoin riippuvainen. (Martin 2016, 164-184, 198-199.) Nuoren ja vanhemman käsitys nuoren tavoitteesta voi olla poikkeava. Vanhempien mielipide onkin tärkeä huomioida kuntoutuksessa, mutta päätäntävallan täytyy säilyä nuorella. Vaihtoehdoksi nuorten mielenterveyden ongelmiin on tarjottu myös yksilön vahvuuksia korostavaa asiakasohjausta (Case Management). Tärkeintä tässä lähestymistavassa on henkilökohtaisen ja mielekkään tavoitteen saavuttaminen. Muita elementtejä ovat hoitovaihtoehtojen tarjoaminen, yksilöllinen neuvonta, ertityisesti tunteiden ja toimintatapojen osalta sekä ratkaisukeskeisyys. (Mendenhall \& Grube 2016, 369-375.)

Nuoret kuntoutujat ovat olleet kaikkein tyytyväisimpiä avomuotoiseen kuntoutukseen ja toiseksi tyytyväisimpiä laitosmuotoiseen kuntoutukseen. Kuntoutus lisäsi heidän itsevarmuuttaan, elämänhallintataitojaan, kohensi mielialaa sekä lisäsi voimavaroja. (Martin 2016, 155-184.) Nuoret hyötyvät ryhmämuotoisista interventioista (Landa ym. 2016, 3-7). Tutkimuksissa on todettu, että ryhmäintervention avulla sosiaalinen osallistuminen oli lisääntynyt (Martin 2016, 155-184) ja nuorilla ei ollut yhtä suurta riskiä sairastua psykoosiin (Landa ym. 2016, 
3-7). Ryhmässä harjoittelu mahdollistaa osallistujille oppimisen toisiltaan ja tarjoaa tosielämän kokemuksia ja ongelmanratkaisukeinoja (Morin \& Franck 2017, 4).

\section{Tavoitteet osana ihmisen elämää}

\subsection{Sosiokognitiivinen teoria}

Kuntoutuksessa hyödynnetään psykologisia teorioita, joista alla esiteltävä Albert Banduran sosiokognitiivista teoriaa on luultavasti käytetyin (Järvikoski ym. 2015, 25). Bandura on kehittänyt 1980-luvulta saakka sosiokognitiivista teoriaa, joka käsittelee muun muassa tavoitteiden asettelua. Teorian keskeisiä käsitteitä ovat: toimijuus (agency), pystyvyys (efficacy) ja pystyvyysodotukset (self-efficacy believes). (Bandura 2000, 75; Bandura 2001,6-11; Bandura 2006; 164-165.) Toimijuus on sitä, että saa asioita aikaan omalla toiminnallaan (Bandura 2001, 2). Toimijuuden voidaan ajatella olevan henkilökohtaista, valtuutettua ja yhteistä. Valtuutetulla toimijuudella tarkoitetaan sitä, että ihmiset etsivät toisia ihmisiä auttamaan itseään saavuttamaan tavoitteita. Yhteisellä toimijuudella tarkoitetaan toimijuutta ryhmässä yhteisen tavoitteen saavuttamiseksi. Tämä ei kuitenkaan tarkoita, että ryhmällä olisi oma toimijuutensa. Sen sijaan jokaisen henkilökohtainen toimijuus ja tavoitteet ovat ryhmän sisällä. Ryhmän ja yksilön tavoitteiden ollessa linjassa voidaan saavuttaa hyvä lopputulos. (Bandura 2000, 75; Bandura 2001, 13-14; Bandura 2006, 165.)

Sosiokognitiivisessa teoriassa ajatellaan, että toimijuuden sisällä on osa-alueita. Yksin näistä osa-alueista on ennakointi, joka on keskeinen osa-alue tavoitteiden asettelun kannalta. Ennakointi on enemmän kuin tulevaisuuden kuvittelua tai tarkkoja suunnitelmia tulevasta. Ennakointi on sitä, että yksilö asettaa itselleen tavoitteita ja arvioi mahdollisia lopputulemia. Tämä mahdollistaa yksilön ohjautumista ja motivoitumista toimintaan. (Bandura 2001, 7; Bandura 2006, 164.) Yksilö määrittää tavoitteitaan myös tehdäkseen vaikutuksen tai miellyttääkseen toisia. Yksilön arvomaailma vaikuttaa asetettuihin tavoitteisiin. Tavoitteet eivät välttämättä suoraan motivoi yksilöä toimimaan, vaan arvioimaan toimintaansa suhteessa tavoitteisiin. Tämä mahdollistaa, 
että yksilö saa tyydytystä toiminnasta jo ennen varsinaista tavoitteen saavuttamista. Tavoitteiden laatu vaikuttaa myös niiden arviointiin, erityisesti niiden sopiva haastavuus sekä ajallinen kesto. Lyhyen aikavälin pienemmät tavoitteet määrittävät, mitä yksilö tekee tässä ja nyt. Ihmiset hyötyvät eniten hierarkkisesta tavoitteiden asettelusta, jossa on pitkän aikavälin tavoitteita sekä lyhyen aikavälin tavoitteita. (Bandura 2001, 5,8.)

Kokemus omasta toimijuudesta, pystyvyys ja erityisesti pystyvyysodotukset vaikuttavat tavoitteiden valintaan ja tavoitteisiin sitoutumiseen (Bandura 2000, 75). Toisaalta pystyvyysodotukset vaikuttavat myös yksilön toimijuuteen (Bandura 2001, 10; Bandura 2006, 170). Esimerkiksi nuoren kokemus omasta oppimiskyvystä vaikuttaa koulutukseen hakeutumiseen sekä sitoutumiseen. Kokemus, että selviää opinnoista, sitouttaa opiskeluihin paremmin, kuin aiemmat epäonnistumiset. Pystyvyysodotukset vaikuttavat yksilön motivaatioon, tunne-elämän hyvinvointiin sekä tavoitteiden saavuttamiseen (Bandura 2006, 171).

\subsection{Tavoitteet nuoruudessa}

Silverman Nair (2003) on kirjallisuuskatsauksessaan jaotellut elämän tavoitteet hierarkiaksi. Ylimmällä tasolla ovat idealisoituun minäkuvaan liittyvät tavoitteet, jotka näkyvät abstrakteina motivaation ilmentyminä, esimerkiksi maine ja varallisuus. Hierarkian seuraavalla tasolla ovat henkilökohtaiset tavoitteet, kuten ura ja perheen perustaminen. Sen jälkeen ympäristön vaatimuksiin liittyvät tavoitteet, kuten hyvien kouluarvosanojen tavoitteleminen. Alimmalla tasolla hierarkiassa ovat välittömiin toimintoihin liittyvät tavoitteet, kuten lukeminen tiettyyn kokeeseen. Hierarkian alemmat tasot mahdollistavat ylempien tavoitteiden toteutumista. (Silverman Nair 2003, 193.)

län mukaisen kehityksen voidaan kuvata etenevän kehitystehtävien kautta, jotka ovat tietyssä iässä läpikäytäviä prosesseja (Nurmi \& Salmela-Aro 2000, 89, 92). Yksilöiden tavoitteet heijastelevat heidän ikätasolleen kuuluvia kehitystehtäviä (Nurmi 1992, 487-508). Esimerkki kehitystehtävästä voisi olla peruskoulun päättäminen 15vuotiaana. Kehitystehtävät perustuvat yhteiskunnan normeihin, ihmisen kehityksen 
biologiaan tai yksilön omiin toiveisiin ja tavoitteisiin. Kehitystehtävien näkökulmassa ajatellaan, että tietyssä kulttuurissa tietyn ikäisenä on normatiivista tehdä tietynlaisia asioita. (Nurmi \& Salmela-Aro 2000, 89.)

Nuoressa aikuisuudessa elämän tavoitteet liittyvät usein koulutukseen, ammatinvalintaan, parisuhteen ja perheen perustamiseen sekä mieluisien sosiaalisten ryhmien löytämiseen (Silverman Nair 2003, 195). Suomalaisten nuorten tavoitteista peruskoulun yläluokilla ja lukiossa yleisimpiä ovat koulutukseen liittyvät tavoitteet. Nuorilla on myös harrastuksiin, ystävyyssuhteisiin, perheeseen ja terveyteen liittyviä tavoitteita. län myötä yleistyvät työhön, itsensä kehittämiseen ja seurusteluun liittyvät tavoitteet. (Nurmi ym. 2014, 153-154.) Vaikea vammaiset nuoret pitivät tärkeimpinä saavutettavina asioina ennen 30 ikävuotta onnellisuutta sekä läheisiä ja luottamuksellisia ystävyyssuhteita. He pitivät tärkeänä myös terveellisiä elämäntapoja, omaa kotia ja vakaata taloudellista tilannetta. Yli puolelle vastanneista tärkeää oli myös hyvä fyysinen kunto, riittävä vapaa-aika, työ ja ammatillinen koulutus. Työn merkitys tavoitteena korostui niillä, jotka olivat ammatillisen koulutuksen piirissä. (Martin 2016, 118-121.)

\subsection{Tavoitteet kuntoutumisessa}

Useissa mielenterveyskuntoutuksen interventioista on keskeisessä roolissa tavoitteiden asettelu (ks. Gee ym. 2016, 1; Svedberg ym. 2014, 757; Lindström ym. 2013, 731). Morin \& Franck (2017) ovat korostaneet sen merkitystä (2). Myös nuoret ovat kokeneet tärkeäksi terapeuttisessa työskentelyssä yhteisen tavoitteen eteen työskentelyn (Gee ym. 2016, 3). Toli, Webb \& Hardy toteavat, että mielenterveyskuntoutujilla voi kuitenkin olla erityisiä hankaluuksia saavuttaa tavoitteita. Toimintasuunnitelmien muodostaminen tavoitteita kohti auttaa tavoitteiden saavuttamisessa. (Toli ym. 2016, 82-83.) Kuntoutuksen tavoitteiden asettelun tulisikin olla systemaattinen ongelmanratkaisuprosessi, jossa huomioidaan ympäristön odotukset suhteessa yksilön taitoihin ja arvoihin (Anthony \& Farkas 2009, 26).

Bovend`Eerdt ja kumppaneiden (2009) mukaan on yllättävän vähän tutkimusta siitä, miten kuntoutuksen tavoitteet tulisi asetella. Tavoitteiden asettelussa käytettäviin 
menetelmiin ei ole olemassa selkeitä kriteereitä. Esimerkiksi tulisiko asiakkaan tai hänen läheistensä osallistua tavoitteiden asetteluun, mikä on sopiva määrä tavoiteltavia asioita kerrallaan ja mikä on sopiva aikamääre, jonka jälkeen tavoitteiden saavuttamista arvioidaan. (Bovend`Eerdt ym. 2009, 352-357.) Bovend`Eerdt ja kumppaneiden (2009) mukaan on sovittu, että tavoitteiden tulee olla tarkkoja, mitattavia, tavoiteltavia, soveltuvia ja sidottuja aikaan (352-357; ks. myös Clarke,Crowe Oades \& Deane 2009, 292.) Tavoitteiden tulisi olla myös tarpeeksi haastavia sekä realistisia, siten että kuntoutujan on mahdollista saavuttaa ne (Lindström ym. 2013, 738; Clarke ym. 2009, 292; Locke \& Latham 2002, 708; Macpherson, Jerrom, Lott \& Ryce 1999, 96). Palautteen saaminen tavoitteiden toteutumisesta on myös tärkeää (Locke \& Latham 2002, 708).

Kuntoutujan yksilöllinen elämäntilanne ja omat päämäärät tulisi huomioida kuntoutuksen suunnittelussa. Kuntoutujan mielipiteiden kuuleminen voi mahdollistaa tehokkaampaa kuntoutuksen tavoitteiden toteutumista. (Henderson \& Jackson 2017, 12; Martin 2016, 197; Puumalainen, Härkäpää \& Järvikoski 2014, 16-17, Toivonen 2010, 23.) Kuntoutuksen tavoitteiden tulisi tukea yksilön elämäntavoitteita ja kehitystehtäviä, jolloin ne voivat motivoida osallistumaan kuntoutukseen. (Martin 2016, 197; Eklund \& Tjörnstrand 2013, 441-442; Silverman Nair 2011, 192, 197-200; Toivonen 2010, 23) Tavoitteiden tulisi myös tukea minäpystyvyyttä (Clarke ym. 2009, 292). Yksilön osallistumista omien tavoitteidensa asetteluun tukevat henkilökohtaisten teemojen ohjaama tavoitekeskustelu, kuntoutujan oma valmius tavoitteiden asetteluun, omaisten mukana olo tavoitteiden asettamisprosessissa sekä tarkoituksenmukaiset osallistavat työkalut. (Alanko ym. 2017, 32.)

Martin (2016) on tehnyt tutkimusta Kelan vaikeavammaisten lääkinnällistä kuntoutusta saaneista nuorista. Nuorilla oli opiskeluun, terveyteen ja toimintakykyyn, ihmissuhteisiin, harrastuksiin ja työelämään liittyviä tavoitteita. Opinnoissa olevilla oli enemmän opiskeluihin liittyviä tavoitteita kuin niillä, jotka olivat eläkkeellä. (Martin 2016, 118-121.) Puolestaan Shadmi ja kollegoiden (2017) mukaan psykiatriseen kuntoutukseen osallistuneilla oli eniten työhön ja vähiten perhesuhteisiin sekä taloudenhallintaan liittyviä tavoitteita. Verrattaessa ammattilaisten ja kuntoutujien ajatuksia tavoiteltavista asioita yhtenäisyys oli vain 54 \%. Parhaiten yhteneväisiä tavoitteet oli- 
vat työn osalta ja vähiten mielenterveyteen liittyvien tavoitteiden osalta. Yleisesti ottaen 75 \% tutkittavista arvioi saavuttaneensa vähintään yhden tavoitteistaan ainakin osittain. (Shadmi ym. 2017, 1313.)

Moranin ja kollegoiden (2017) tutkimuksessa mielenterveyskuntoutujien tavoitteet oli jaettu seitsemään kategoriaan: säilyttää nykyiset saavutukset nykyisillä osa-alueilla, suoriutua paremmin nykyisillä osa-alueilla, saavuttaa jotakin uutta, valtaistua/kehittää itseään, opiskeluun liittyvät, sosiaalinen elämään liittyvät ja muut tavoitteet. Yleisesti ottaen se, että omasi henkilökohtaisia tavoitteita oli positiivisessa yhteydessä henkilökohtaiseen toipumiseen. Mikään tavoitekategoria ei kuitenkaan kohentanut henkilökohtaista toipumista verrattuna toiseen. Näin ollen voidaan päätellä, ettei tavoitetyypillä ole yhteyttä toipumiseen vaan kyvyllä asettaa tavoitteita. (Moran, Westman, Weissberg \& Melamed 2017, 96-97.)

Lectome, Wallace, Perrault \& Caron (2005) on todennut, että kuntoutuksen tavoitteiden asettelussa ammattilaiset tukevat ennemmin sairauden oireiden tai haitallisen käytöksen vähentämiseen liittyviä tavoitteita. Vähemmälle huomiolle jäävät konkreettisten asioiden opettelu tai esimerkiksi hengellisten asioiden käsittely tavoitteiden asettelussa. Tarjottujen mielenterveyskuntoutuspalveluiden tulisi tukea tavoitteiden saavuttamista. Tutkimuksen mukaan yhteneväisyys tavoitteiden ja palvelutarjonnan välillä kohensi elämäntyytyväisyyttä. (Lecomte ym. 2005, 209-211.)

Kouluttamalla ammattilaisia kuntoutusorientaatioon liittyen saavutettiin työskentelyssä parempi toipumisorientaatio. Tämä lisäsi kuntoutuksen tavoitteiden suuntautumista kohti toipumista sekä kuntoutujien että ammattilaisten mielestä. (Kymalainen, Henze, Deluca, Mitton, Walton, Duffy, Kapungu, Lefebvre, Alexander \& Pinsky 2010, 324.) Ammattilaisten kouluttaminen tavoitteiden asetteluun lisäsi kirjattuja tavoitteita rekisteriaineistossa $16 \%$ :Ila. Yli puolet näistä tavoitteista oli määritelty tarkasti ja ne olivat mitattavia. Ammattilaisten koulutuksen jälkeen tavoitteissa näkyivät myös useammin asiakkaan arvot tai laajemmat elämäntavoitteet. Sen sijaan rekisteristä harvoin löytyi suunnitelma tavoitteiden seuraamiseksi ja määritelty tuki tavoitteiden saavuttamiseen. (Clarke ym. 2009, 295-297.) 


\subsection{Goal Attainment Scaling (GAS)}

Kela on 2000-luvulta lähtien korostanut kuntoutuksen tavoitteiden asettelun merkitystä ja ottanut käyttöön palveluissaan Goal Attainment Scaling (GAS)-menetelmän sen tueksi (Toivonen 2010, 23) GAS on asiakaslähtöinen ja systemaattinen tavoitteiden asettamismenetelmä. Se mahdollistaa myös tavoitteiden saavuttamisen arvioinnin. GAS-menetelmän tukena voidaan käyttää SMART-tavoitteiden asettelutyökalua. SMART-menetelmä koostuu neljästä vaiheesta: tavoiteltavan toiminnan valinta, tuen tarpeen määrittäminen, osallistumisen määrällistäminen ja aikamääreen määrittäminen. (Bovend’Eerdt ym. 2009, 352-357.)

Kelan GAS-menetelmään liittyneen arviointitutkimuksen mukaan tavoitteiden saavuttamista mahdollistavat ja haittaavat tekijät muodostivat jokaisen yksilön kohdalla ainutlaatuisen prosessin. Edistäviä tekijöitä olivat motivaatio ja sitoutuminen, kuntoutus, omaisten ja läheisten tuki, vastuunottaminen, harjoittelu arjessa, vertaistuki, rutiinit, apuvälineet, GAS-tavoitteiden seuranta ja yleinen toimintakyvyn kohentuminen. Estäviä tekijöitä olivat toimintakyvyn heikkeneminen/vaihtelu. Muita estäviä tekijöitä olivat epätarkoituksenmukaiset tavoitteet, heikko tavoitteiden saavuttamiseen annettu tuki sekä tavoitteiden saavuttamista estävät ympäristötekijät. (Alanko ym. 2017, 4, 9, 43-44.) GAS-tavoitteita on tutkimuksellisesti luokiteltu myös käyttäen jaottelun pohjana ICF-viitekehyksen luokittelua. GAS-tavoitteiden asettelua tukee ICF-viitekehyksen käyttö tukena. (Pohjola \& Roivanen 2016, 48-49.)

GAS-menetelmä voi tukea asiakkaan ja ammattilaisen välistä vuorovaikutussuhdetta ja luoda yhteistä kieltä heidän välilleen. Se voi myös valtaistaa asiakasta sekä mahdollistaa tavoitteiden toteutumista muodostamalla toimintasuunnitelmaa kohti tavoitteita. GAS-menetelmä lisää tavoitteiden saavuttamisen todennäköisyyttä merkittävästi. (Tabak \& Link 2015, 183.) Laadullisessa tutkimuksessa on todettu GASmenetelmän soveltuvan käyttöön nuorten kanssa. Tässä työskentelyssä on tärkeää ammattilaisen ja nuoren välinen yhteistyö tavoitteiden asettelussa sekä se, että nuori saa GAS-lomake itselleen. (Cairns, Kavanagh, Dark, McPhail 2015, 257.) 


\section{Opinnäytetyön tarkoitus ja tavoitteet}

Tämän opinnäytetyön tarkoituksena oli ymmärryksen lisääminen nuorten mielenterveyskuntoutuksessa tavoiteltavista asioista ja ilmiöistä, erityisesti asumiskuntoutuksen piirissä. Ymmärryksen lisääntymisen avulla voidaan kehittää nuorten mielenterveyskuntoutuksen tavoitteiden asettelua asumiskuntoutuksessa esimerkiksi tavoitteiden asetteluprosessin ja kirjaamiskäytäntöjen osalta. Opinnäytetyön tavoitteena oli nuorille mielenterveyskuntoutujille asumiskuntoutuksessa asetettujen tavoitteiden tarkasteleminen ja kuvaileminen.

Tutkimuskysymykset olivat:

1. Millaisia kuntoutuksen tavoitteita nuorten mielenterveyskuntoutujien asumiskuntoutuksessa kerätystä aineistosta löytyy?

2. Millaisia asioita tai ilmiöitä esiintyy nuorten mielenterveyskuntoutujien asumiskuntoutuksen tavoitteissa?

\section{Opinnäytetyön toteutus}

\subsection{Laadullinen tutkimus}

Voidaan ajatella, että tieteellinen tieto alkaa siitä, mihin arkitieto päättyy. Tutkimuksen avulla vastataan kysymyksiin todellisuuden luonteesta. (Laaksovirta 1983, 12.) Todellisuuden luonteen voidaan ajatella olevan esimerkiksi muuttumaton ja ehdottomasti totta tai syntyvän ihmisten kokemuksissa ympäröivästä maailmasta (Tuomi \& Sarajärvi 2018, 1.3). Tutkimus on järjestelmällistä tuotettua tietoa tietystä ilmiöstä. Tutkimustieto syntyy konkreettisen tutkimustyöskentelyn kautta, eikä siis sillä tavoin ajateltuna ole abstraktia. (Laaksovirta 1983, 12.) Tutkimuksen tavoitteista riippuen valitaan, mitä tutkimustapaa käytetään (Morgan 2014, 8; Hirsjärvi \& Hurme 2008, 27).

Laadullisesta tutkimuksesta käytetään synonyymejä kvalitatiivinen tutkimus, pehmeä tutkimus (Eskola \& Suoranta 1998, Laadullisen tutkimuksen määrittelyä), ymmärtävä- 
ja ihmistutkimus (Tuomi ja Sarajärvi 2018, 1.2). Tuomen ja Sarajärven $(2018,1.2)$ mukaan laadullinen tutkimus voidaan nähdä kvalitatiivisen tutkimuksen suomennoksena, mutta muutoin synonyymit eivät täysin vastaa alkuperäisiä termejä. Laadullisen tutkimuksen pyrkimyksenä on kuvata ja ymmärtää ilmiöitä (Tuomi \& Sarajärvi 2018, 3.4). Laadullisessa tutkimuksessa maailma rajautuu omalla tavallaan. Yleisimmin sen tutkimuskohteena on kieli, koska inhimillinen elämä on suurelta osin kielellistä vuorovaikutusta. (Eskola \& Suoranta 1998, Erilaiset kielikäsitykset ja puheen keskeisyys sosiaalisen todellisuuden rakentajana.)

Retrospektiivisessä tutkimusasetelmassa tutkitaan lopputulosta, joka on jo tapahtunut, kun tutkimus aloitetaan. Retrospektiivisessä tutkimuksessa käytetään tyypillisesti tietokantoja, potilastietoja ja haastatteluja. Tämän tutkimusasetelman etuja ovat yksinkertaisuus, nopeus ja edulliset toteutuskustannukset. Vaikeuksia retrospektiivisessä tutkimuksessa tuottavat aineistoihin luottaminen, kontrolliryhmän hankkiminen, muuttujien kontrolloiminen vaikuttavuuden osoittamiseksi sekä virheiden mahdollisuus. (Salkind, J. 2010, Retrospective Study.)

\subsection{Tutkimuksen aineisto ja aineiston keruu}

Tämän tutkimuksen aineisto on muodostunut nuorten mielenterveyskuntoutujien asumiskuntoutuksessa. Tutkittavan asumiskuntoutusyksikön kuntoutusohjelmassa päätavoitteena on nuoren itsenäinen elämä, sisältäen itsenäisen asumisen. Kuntoutus on muodostunut itsestä huolehtimisen, päivittäisten toimintojen, vapaa-ajan sekä työelämän toimintakokonaisuuksien harjoittelusta. Tutkittavien kuntoutusprosessi oli muodostunut kolme kuukautta kestävästä alkuarviointijaksosta sekä suurimmalla osalla tutkittavista pidemmästä kuntoutusohjelmasta.

Tässä tutkimuksessa käytettiin aineistona asumiskuntoutuksessa muodostunutta rekisteriaineistoa. Tämä vaikutti tutkimuksen toteuttamiseen muun muassa siten, ettei tutkittavilla ollut etukäteen tietoa tutkimuksesta. Tutkimusluvat aineiston käyttöön kerättiin asumiskuntoutuksessa kirjatun rekisteritiedon keräämisen jälkeen. Aineistoa tässä tutkimuksessa käsiteltävään rekisteriin oli kertynyt aikavälillä 1/2011$5 / 2018$. 
Rekisteriaineistosta tutkimuksen aineiston muodostivat kuntoutujien kuntoutustiedotteet ja -suunnitelmat. Aineistossa ilmeni jonkin verran puutteita, koska sitä kirjattaessa ei ollut tiedossa, että sitä käytetään tutkimuskäyttöön. Kirjaamiskäytännöt olivat muuttuneet vuosien 2011-2018 välillä. Vuosina 2006-2012 käytettiin kuntoutuksen suunnitteluun kuntoutussuunnitelmalomaketta. Kuntoutussuunnitelmia päivitettiin tarpeen mukaan. Vuodesta 2011 oli rinnalla käytetty sähköiseen toiminnanohjausjärjestelmään kirjattavaa kuntoutustiedotetta. Kuntoutustiedote oli pitänyt päivittää vähintään puolen vuoden välein vuodesta 2011. Vuoden 2018 alusta lähtien kuntoutustiedote oli pitänyt päivittää kuukausittain.

On myös luultavaa, että osa kuntoutussuunnitelmista ja -tiedotteista oli hävinnyt ennen arkistointia. Ohjeistuksen mukaan kuntoutustiedotteita sai olla sähköisessä järjestelmässä vain yksi kuntoutujaa kohti. Kirjaajan piti tulostaa ja allekirjoittaa kuntoutustiedote ennen uuden muodostamista. Kirjaajat eivät välttämättä olleet aina toimineet ohjeistuksen mukaan, ja siksi tiedotteita oli saattanut tuhoutua. Kunnilla oli myös poikkeavia ohjeistuksia aineiston arkistoinnista ja oli mahdollista, että osa aineistosta oli lähetetty kuntoutujan kotikuntaan arkistoon. Tätä aineistoa ei kerätty tässä tutkimuksessa

Tutkimusjoukkoon sisällytettiin kuntoutujat, jotka olivat olleet kuntoutuksessa aikavälillä tammikuu 2011-heinäkuu 2016 ( $n=98$ ). Aineistosta suljettiin pois ne kuntoutujat $(n=4)$, jotka ovat olleet ainoastaan päiväkuntoutuksen asiakkaita eli toisin sanoen kuntoutujat, jotka eivät ole käyneet läpi asumiskuntoutuksen alkuarviointijaksoa tai kuntoutusohjelmaa. Tutkittavat olivat iältään 18-29-vuotiaita. Aineistossa olevien henkilöiden diagnooseja olivat erilaiset psykoosisairaudet, mielialahäiriöt, persoonallisuushäiriöt (erityisesti epävakaa persoonallisuushäiriö), neuropsykiatriset oireyhtymät ja sosiaalisten tilanteiden pelko. Lisäksi kuntoutujilla saattoi olla päihdehäiriö, kehityksen viivästymä tai heikentyneet kognitiiviset valmiudet. Kuntoutusjaksojen kestot vaihtelivat kolmesta kuukaudesta useisiin vuosiin.

Kuviossa 2. on kuvattu tutkittavien valikoituminen tutkimukseen. Tutkimusjoukko muodostui 94 henkilöstä, joista 34 antoi suostumuksensa osallistua Psykiatrisen kuntoutuksen vaikuttavuus-tutkimushankkeeseen, jonka osa tämä opinnäytetyö oli. Tästä henkilömäärästä tässä tutkimuksessa käytettiin harkinnanvaraisella otannalla 
kerättyä 16 tutkittavan näytettä. Laadullisessa tutkimuksessa on tyypillistä, että aineisto on harkinnanvaraisesti poimittu näyte. Harkinnanvarainen näyte ei ole satunnaisesti valikoitu vaan sen valikoitumiseen on jokin muu peruste. (ks. Eskola \& Suoranta 1998, Harkinnanvarainen otanta).

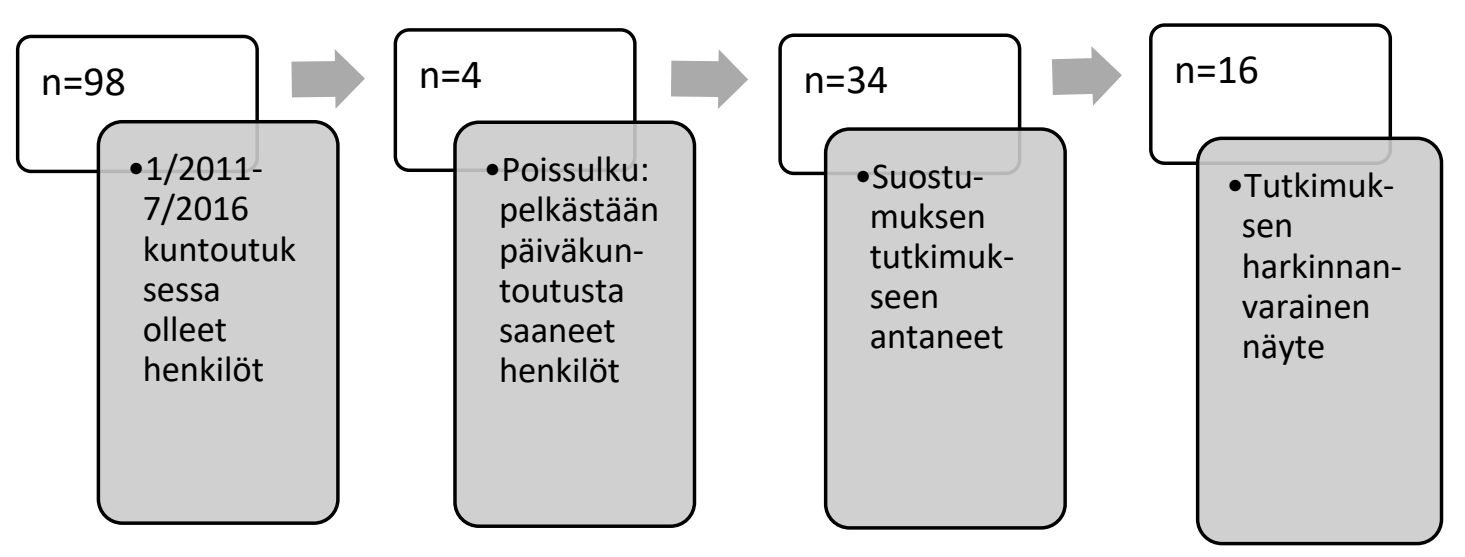

Kuvio 2. Tutkittavien valikoituminen tutkimukseen

Harkinnanvarainen näyte muodostui tässä tutkimuksessa aineiston keruun aikana. Asumiskuntoutuksessa kerätystä rekisteriaineistosta kopiotiin tutkittavien arkistossa säilytetyt kuntoutustiedotteet ja/tai -suunnitelmat. Sähköisestä järjestelmästä tulostettiin tutkittavien kuntoutustiedotteet. Harkinnanvaraisen näytteen muodostuminen eteni yhdessä aineiston keruun kanssa. Kun tutkittavalta oli saatu tutkimuslupa, tutkittava lisätiin tutkimusrekisteriin. Jokaiselle tutkittavalle muodostui numeraalinen tunniste kahdesta 35:een. Aineiston keruu alkoi tutkittavasta tunnistenumerolla 2. Arkistosta ja sähköisestä järjestelmästä haettiin kyseisen tutkittavan tiedotteet ja/tai suunnitelmat. Sen jälkeen kerättiin tunnistenumerolla 2. olevan tutkittavan kanssa samalla sukunimen ensimmäisellä kirjaimella alkavista tutkittavista olevat tiedotteet. 
Näin siksi, että kirjallinen arkisto oli järjestetty aakkosjärjestykseen sukunimen perusteella. Seuraavaksi edettiin järjestysnumeroltaan seuraavaan tutkittavaan ja niin edelleen, kunnes 16 henkilön näyte oli kerätty.

Kuntoutussuunnitelmien ja -tiedotteiden määrä vaihteli aineistossa 1-11 kappaleeseen tutkittavaa kohtaan. Tutkittavista neljällä oli vain yksi tiedote ja vain yhdellä 11 tiedotetta. Lopuilla 11 tutkittavalla oli $2-8$ tiedotetta ja/tai suunnitelmaa. Aineistossa esiintyi enemmän tiedotteita ja suunnitelmia henkilöillä, jotka olivat olleet kuntoutuksessa lähempänä nykyhetkeä. Toisaalta aineistoa oli luonnollisesti enemmän tutkittavilla, joiden kuntoutus oli jatkunut pidempään. Laadullisessa tutkimuksessa aineiston koko ei ratkaise tutkimuksen onnistumista, eikä sen määrittämiseksi ole kriteerejä. Tässä opinnäytetyössä aineiston määrä ei ollut ratkaiseva tekijä analyysin toteuttamisessa. (ks. Eskola \& Suoranta 1998, Harkinnanvarainen otanta, Aineiston kattavuus.)

Aineistoa kerättäessä dokumenteista poistettiin yliviivaamalla etu- ja sukunimet, osoitteet, henkilötunnukset, puhelinnumerot ja muut tunnistetiedot, kuten paikkakuntien, yritysten tai yhteistyökumppanien nimet. Tiedotteiden ja suunnitelmien päivämäärät jäivät näkyviin. (ks. Kuula 2006, 112). Tässä vaiheessa kuntoutussuunnitelmat ja -tiedotteet luettiin ensimmäistä kertaa. Laadullisessa tutkimuksessa on tavanomaista liikkua aineiston keruun, analyysin ja tulkinnan välillä (Eskola \& Suoranta 1998, Laadullisen tutkimuksen arviointi). Aineiston kerääminen ja analyysi ovat toisiaan täydentävät osat kokonaisuutta (Tuomi \& Sarajärvi 2018, 2.4).

\subsection{Aineiston analyysi}

Sisällönanalyysillä tarkoitetaan menetelmää, jota voidaan käyttää laadullisessa tai määrällisessä tutkimuksessa aineisto- tai teorialähtöisesti. Laadullista sisällönanalyysiä käytetään usein terveysalan tutkimuksessa. (Elo \& Kyngäs 2017, 107; Graneheim \& Lundman 2004, 105; Cavanagh 1997, 5-7.) Käytettäessä sisällönanalyysiä on tarkoituksena luoda malli, jolla ilmiötä voidaan tarkastella teoreettisessa muodossa. Sisällönanalyysi soveltuu kirjallisen, suullisen ja kuvallisen aineiston analysointiin. Siinä pyritään systemaattisesti ja objektiivisesti kuvailemaan aineistoa. (Elo \& Kyngäs 2007, 
107.) Tässä tutkimuksessa käytettiin laadullista aineistolähtöistä sisällönanalyysiä asumiskuntoutuksessa muodostuneen rekisteriaineiston analysointiin. Rekisteriaineisto muodostaa tutkimuksen analysointikohteen (soveltaen Graneheim \& Lundman 2004, 106).

Tuomi ja Sarajärvi (2018) jaottelevat laadullisen tutkimuksen sisällönanalyysin muodot luokitteluun, teemoitteluun ja tyypittelyyn. Luokittelussa sisältöyksiköiden määrä aineistossa lasketaan ja teemoittelussa aineistosta etsitään pääteemoja, jotka voivat olla niin sanotusti piileviä. Tyypittelyssä aineisto määritetään tietyn tyyppisiksi ryhmiksi, joista luodaan yleistyksiä. Sisältöyksiköiden esiintymisellä aineistossa ei ole merkitystä, vaan tietyt ilmiötä koskevat asiat määritellään saman kategorian alle yleistykseksi (Tuomi \& Sarajärvi 2018, 4.1.) Tämä analyysi oli lähimpänä tyypittelyä, koska esimerkiksi sisältöyksiköiden toistumista aineistossa ei ole laskettu (ks. numeraalinen analyysi laadullisessa sisällön analyysissä Cavanagh 1997, 14).

Tutkimuskysymysten perusteella aineiston analyysiin valikoituivat sisältöyksiköksi kuntoutuksen tavoitteet. Sisällön analyysin perinteen mukaisesti etsittiin sanoja ja lauseita, joilla oli sama merkitys. Huomioitiin lauseet, joissa käytettiin sanaa tavoite, päämäärä, tähtäin, pyrkimys tai muu vastaava tavoite-sanan synonyymi. Lisäksi huomiotiin niin sanotusti tavoitteiden vastakohdat eli haasteet ja ongelmat. Tekstissä näitä asioita oli kuvattu esteenä tavoitteisiin pääsemiseksi ja pyrkimyksenä oli päästä näistä asioista eroon kuntoutumisen edistämiseksi. (ks. Elo \& Kyngäs 2007, 107-109; Graneheim \& Lundman 2004, 106-107.) Analyysi aloitettiin lukemalla toiseen kertaan kuntoutussuunnitelmat ja -tiedotteet ja samalla etsittiin kirjallisesta aineistosta kuntoutuksen tavoitteita. Löytyneet sanat tai lauseet merkittiin yliviivaamalla värikynällä eli koodaamalla (ks. Tuomi \& Sarajärvi 2018, 4.1). Löydetyt yksiköt, sanat tai lauseet, puhtaaksikirjoitettiin Excel-taulukkoon.

Sisältöyksiköistä muodostui Excel-taulukko, jossa olivat tutkittavien kaikki tavoitteet kuntoutuksen ajalta ajallisessa järjestyksessä tutkittavakohtaisissa taulukoissa. Kirjoitettaessa tavoitteet tiedotteista ja suunnitelmista Excel-taulukkoihin tekstiä muokattiin mahdollisimman vähän. Tekstiä ei kondensoitu eli tiivistetty (ks. Graneheim \& Lundman 2004, 106). Tekstistä korvattiin kuitenkin esimerkiksi poistetut yhteistyökumppanien nimet selitteillä, kuten etsivä nuorisotyö ja ammatillinen kuntoutus. 
Lauseen keskeltä poistetut sanat korvattiin merkinnällä "piste piste piste". Tarvittaessa lisättiin lauseeseen kuvaavan substantiivin sulkuihin, esim. "Niiden käsittelyä (tunteiden)". Henkilöiden nimet jätettiin korvaamatta tekstissä. Kirjoitusvirheitä ei korjattu.

Seuraavassa analyysin vaiheessa käytettiin värikoodausta. Esimerkiksi vihreät tavoitteet olivat itsestä huolehtimiseen liittyviä ja violetit itsenäiseen asumiseen liittyviä. Tässä vaiheessa kirjoitettiin Excel-taulukoihin sanoja ja huomioita, joita tutkijalla analyysin aikana heräsi. Tämän jälkeen aineistoa analysoitiin, jäsenneltiin ja muodostettiin yksittäisistä sisältöyksiköistä ryhmiä. Ryhmittelyn vaihe aloitettiin analysoimalla yksittäisten tutkittavien tavoitteita ja muodostamalla niistä ryhmiä. Ryhmistä lähdettiin muodostamaan pääkategorioita. Tämän jälkeen palattiin alkuperäiseen aineistoon, joka luettiin uudelleen. Tarkistettiin, että alkuperäinen aineisto ja saadut yksittäisten tutkittavien tavoiteluokat olivat yhteneväisiä. Tarvittaessa tehtiin lisäyksiä. (soveltaen Graneheim \& Lundman 2004, 106.)

Liitteen 1. taulukossa 1. kuvataan Ikätasoiset toiminnalliset roolit pääkategorian muodostumisen prosessia, nostamalla yksittäisiä sisältöyksiköitä esimerkeiksi. Näistä sisältöyksiköistä ovat muodostuneet alaryhmät ja ryhmät. Ryhmiä yhdistelemällä ovat syntyneet pääkategoriat. Esimerkiksi sisältöyksikkö "itsenäistymään perheestään”, kuuluu ylimpään alaryhmään itsenäistyminen vanhemmista ja ryhmään autonomian saavuttaminen ja lopulta pääkategoriaan Ikätasoiset toiminnalliset roolit. Kun taas sisältöyksikkö "Lääkkeestä..psykoosioireisiin..Jatkossa valmis harkitsemaan sen kokeilemista uudelleen" kuuluu alimpaan alaryhmään lääkitysmuutokset, keskimmäiseen alaryhmään lääkityksen hoitaminen ja ylimpään alaryhmään itsestä huolehtiminen, pääkategorian säilyessä samana.

Liitteen 2. taulukossa 2. on kuvattu Sosiaalinen osallisuus pääkategorian muodostumista. Tässä pääkategoriassa on kaksi alaryhmää. Esimerkiksi sisältöyksikkö "Työkeilua asumiskuntoutuksen ulkopuolella tullaan suunnittelemaan ja aloittamaan kevyesti -esim. 1pvä/vko liiallisen stressin välttämiseksi." kuuluu alempaan alaryhmään Tuettuun työllistymiseen osallistuminen ja ylempään alaryhmään Työllistyminen. Ryhmään Työelämä ja opiskelu ja pääkategoriaan Sosiaalinen osallisuus. Kun taas sisältöyksikkö "vaikeaa tulla puhumaan voinnin heikkenemisestä ja ahdistuksestaan" 
kuuluu ylempään alaryhmään Vuorovaikutustaitojen harjoittelu ohjaajien kanssa ja pääkategoriaan Sosiaalinen osallisuus.

Kolmannen pääkategorian Sisäinen resilienssi muodostuminen on kuvattu liitteen 3. taulukossa 3. Tämä pääkategoria jakautui ryhmiin sekä alempiin ja ylempiin alaryhmiin. Esimerkiksi sisältöyksikkö "Kuntoutujaryhmään osallistuminen alk.3/2015" kuului Kuntoutukseen osallistumisen alempaan alaryhmään ja motivoitumisen ylempään alaryhmään. Toisena esimerkkinä sisältöyksikkö "ajankohtaiseksi painonpudotuksen, johon laadittu yhdessä suunnitelmaa", joka kuuluu terveellisten elämäntapojen ylempään alaryhmään ja fyysisen terveydentilan edistämisen ryhmään.

Yksittäisten tutkittavien analyyseista siirryttiin yhdistävään analyysin, jonka tarkoituksena oli löytää aineistosta tutkimusongelman kannalta keskeinen (ks. Elo \& Kyngäs 2007, 108-109). Aineistosta muodostui Excel-asiakirja, jossa olivat kaikki tähän mennessä löydetyt tavoiteryhmät. Asiakirja tulostettiin, minkä jälkeen manuaalisesti yhdistettiin A4 -papereille tavoitteet, jotka kuuluivat samaan ryhmään (ks. liitteet 1-3). Pääkategorioista ja ryhmistä muodostettiin Word-asiakirjaan kuvioita. Termejä muokattiin prosessin joka vaiheessa, tavoiteryhmiä yhdisteltiin sekä lisättiin eritasoisia alaryhmiä. Pääkategorioiden ja tavoiteryhmien tuli olla homogeenisia ja toisensa poissulkevia. (ks. Graneheim \& Lundman 2004, 106-107; Cavanagh 1997, 10.) Näin syntyivät tutkimuksen pääkategoriat ja ryhmät, jotka näkyvät seuraavassa luvussa olevissa kuvioissa.

\section{Tulokset}

Tulososiossa on kuvattu sisällönanalyysissä muodostuneet pääkategoriat kuvioina. Mikäli pääkategoriassa esiintyvässä ryhmässä on ollut enemmän kuin kaksi selittävää alaryhmää on nämä kuvattu omissa kuvioissaan. Tämä on aina mainittu pääkategoriaa kuvaavassa kuviossa. Joissakin pääkategorian ryhmissä ei ole ollut selittäviä alaryhmiä. 


\subsection{Ikätasoiset toiminnalliset roolit}

Ikätasoisilla toiminnallisilla rooleilla tarkoitetaan tässä analyysissä yksilön kykyä toimia ikätasoisten kehitystehtäviensä ja henkilökohtaisten tavoitteidensa suunnassa. Toiminnallisilla rooleilla viitataan myös yksilön toimintakyvyn eri ulottuvuuksiin, kuten päivittäisiin toimintoihin ja vapaa-ajan toimintoihin. Pääkategoria on kuvattu kuviossa 3.

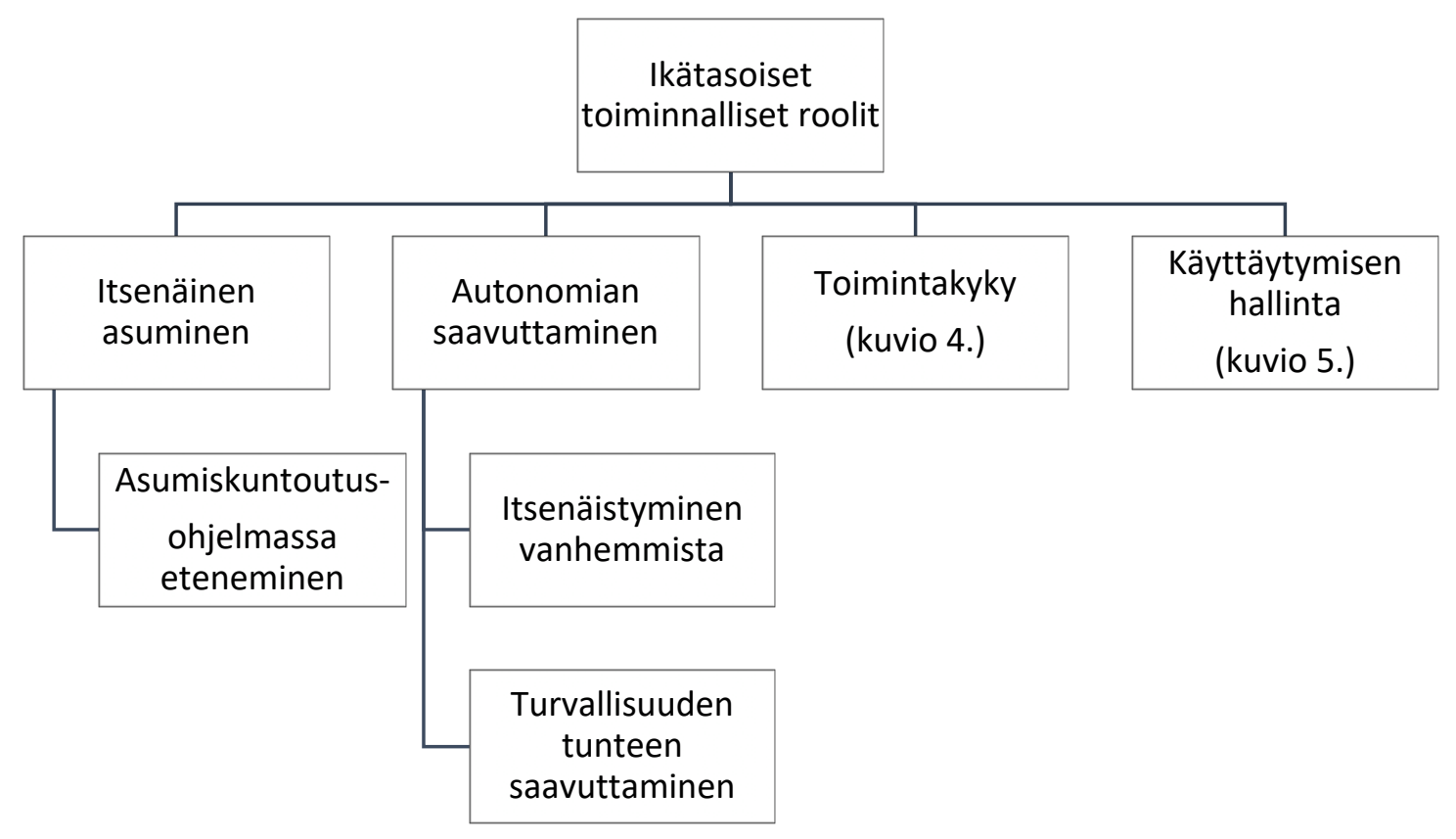

Kuvio 3. Pääkategoria Ikätasoiset toiminnalliset roolit

Itsenäiseen asumiseen liittyviä tavoitteita oli suurimmalla osalla tutkittavista. Esimerkiksi "kyetä asumaan itsenäisesti" tai "itsenäisempään asumiseen siirtyminen". Kahdella tutkittavalla ei ollut mainittu suoranaisesti itsenäiseen asumiseen liittyviä tavoitteita. Toinen heistä asui itsenäisesti ja toisen kuntoutusjakso päättyi kesken. Selittävänä alaryhmänä itsenäiseen asumiseen liittyvissä tavoitteissa olivat asumiskuntoutusohjelmassa etenemiseen liittyvät tavoitteet. Tällöin oli kirjattu kuntoutujan 
pyrkimyksiä siirtyä kuntoutusohjelman neljässä vaiheessa eteenpäin vähemmän tuettuihin asumismuotoihin. Kuntoutuksen vaiheelta toiselle siirtymiseen liittyvissä tavoitteissa oli useammin aikamääreitä kuin muissa tavoitteissa.

Autonomian saavuttamiseen liittyvät tavoitteet kuvasivat yksilön itsenäistymistä ja selviämistä turvallisesti yksin. Tavoitteet liittyivät itsenäistymiseen vanhemmista. Konkreettisesti tämä oli voinut näkyä esimerkiksi nuoren taloudesta huolehtimisessa. Itsenäistymiseen vanhemmista pyrittiin esimerkiksi vähentämällä kotiin suuntautuvia lomia: "Itsenäistymistä tuettiin myös vähentämällä kotilomia yhteisellä sopimuksella". Toisena selittävänä tavoiteryhmänä autonomian saavuttamisen liittyvissä tavoitteissa olivat turvallisuuden tunteen saavuttamiseen liittyvät tavoitteet. Aineiston perusteella yhdistettiin turvattomuuden tunne yksilön vaikeuteen toimia itsenäisesti ilman toisen henkilön turvaa. Aineistossa kuvattiin tutkittavien yksin olemisen pelkoa, tavoitteena oli esimerkiksi: "kehitystä toivotaan yksinolon sietämiseen" (ks. kuvio 3.)

Toimintakykyyn liittyvien tavoitteiden ryhmä ja alaryhmät on kuvattu kuviossa 4. Päivittäisiin toimintoihin liittyvät tavoitteet koskivat ruuan valmistuksen, siivouksen tai vastaavien toimintojen harjoittelua ja toiminnoista suoriutumista. Esimerkiksi: "keskitytään perusjuttuihin kuten siivoukseen". Välineellisiin päivittäisiin toimintoihin liittyvät tavoitteet koskivat asioita, joiden hoitamista vaaditaan päivittäisten toimintojen vuoksi, esimerkiksi kaupassa tai erilaisissa virastoissa asiointia. Taloudenhallintaan liittyviä tavoitteita oli suurimmalla osalla nuorista. Nämä tavoitteet koskivat rahankäytön perustaitoja: "toinen tili helpottamaan rahan käytön hahmottamisen haasteita" tai taloudenhallintaa kokonaisuutena: "saada raha-asiat kuntoon". Taloudenhallinta oli kytköksissä autonomian saavuttamiseen ja erityisesti itsenäistymiseen vanhemmista. 


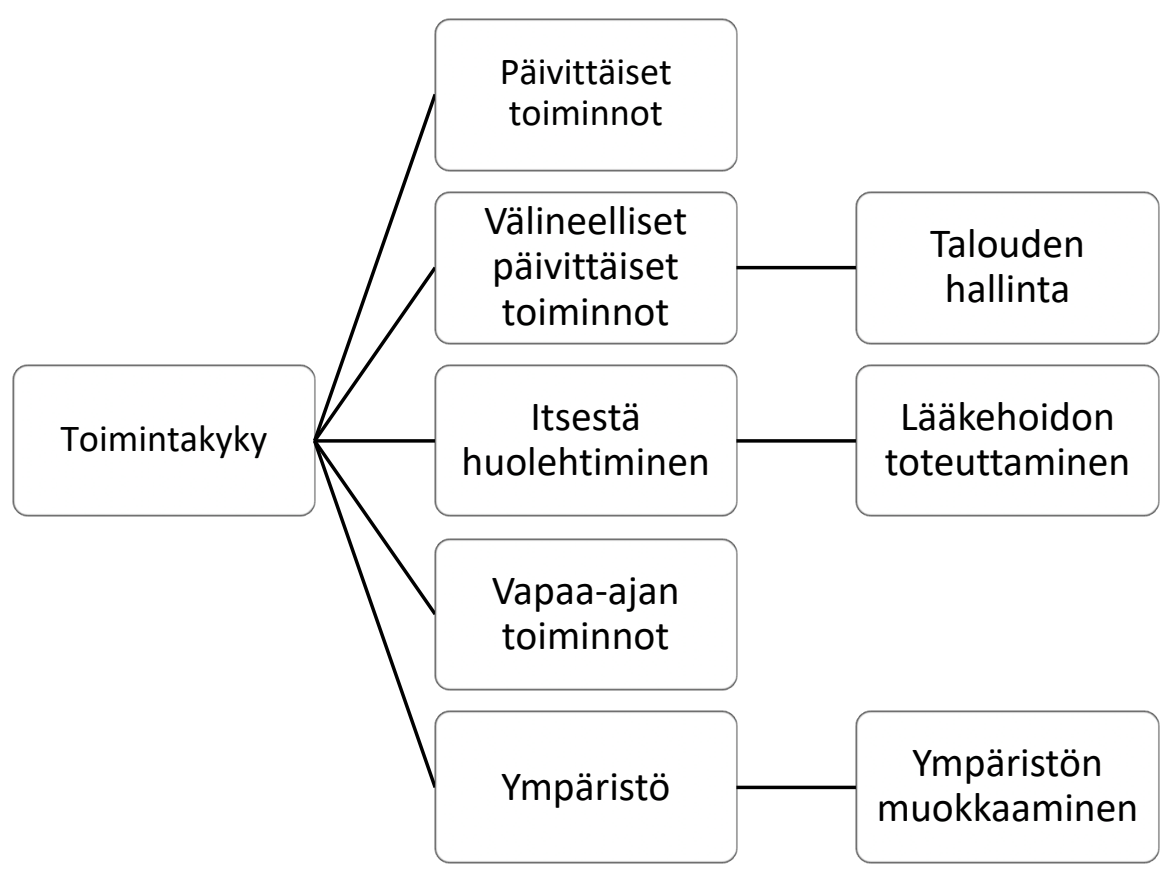

Kuvio 4. Toimintakykyyn liittyvien tavoitteiden ryhmä ja alaryhmät

Varsinaisia itsestä huolehtimiseen liittyviä tavoitteita esiintyi vain yhdellä tutkittavista, eikä niitä oltu kuvailtu sen tarkemmin. Yksinkertaisesti tavoitteeksi oli mainittu itsestä huolehtimisen kohentuminen. Lääkityksen toteuttamiseen liittyviä tavoitteita sen sijaan oli suurimmalla osalla tutkittavista. Nämä tavoitteet koskivat lääkkeiden ottamista ajallaan, lääkkeiden jakamista itselle dosettiin, reseptien uusimista ja lääkkeiden noutamista apteekista. Esimerkiksi "itsenäisesti lääkkeiden ottaminen". Lääkityksen aloittamiseen liittyviä ilmiötä kuvattiin aineistossa kuntoutuksen alkuvaiheessa ja lääkityksen itsenäiseen huolehtimiseen liittyviä kuntoutuksen lopetusvaiheessa. Lääkityksien lopettamiseen liittyviä tavoitteita aineistossa esiintyi vähemmän kuin lääkityksien aloittamiseen liittyviä tavoitteita. Esimerkiksi "Lääkkeestä..psykoosioireisiin..Jatkossa valmis harkitsemaan sen kokeilemista uudelleen" (ks. kuvio 4.).

Vapaa-ajan toimintoihin liittyvät tavoitteet (ks. kuvio 4.) koskivat uusien harrastuksien aloittamista tai vanhojen pariin palaamista. Ympäristöön liittyviä tavoitteita esiintyi aineistossa vähän. Ympäristön muokkaaminen oli toimintaympäristön muok- 
kaamista sellaiseksi, että yksilön toimintakyky kohentuisi "Liian monet äänet tai ympäristön muu levottomuus vaikeuttavat keskittymistä ja kärsivällisyyttä". Ne saattoivat liittyä myös sosiaaliseen ympäristöön ja tuen tarpeeseen siinä "toisinaan kokenut kotiympäristön raskaana".

Käyttäytymisen hallintaan liittyvät tavoitteet on kuvattu kuviossa 5. Tästä alaryhmästä aineistossa esiintyi eniten itsen ja muiden vahingoittamisen välttämiseen liittyviä tavoitteita sekä päihteiden käytön hallintaan liittyviä tavoitteita. Muiden vahingoittamisen hallintaan liittyvät tavoitteet koskivat useimmiten ajatuksia muiden vahingoittamisesta ja tavoitetta, etteivät ajatukset siirry teoksi. Tällaista käyttäytymistä myös pyrittiin kanavoimaan esimerkiksi nyrkkeilysäkin hakkaamiseksi. Impulssikontrollin saavuttaminen liittyi esimerkiksi pyrkimykseen olla rikkomatta tavaroita, tekemättä heräteostoksia tai pelaamatta nettipelejä.

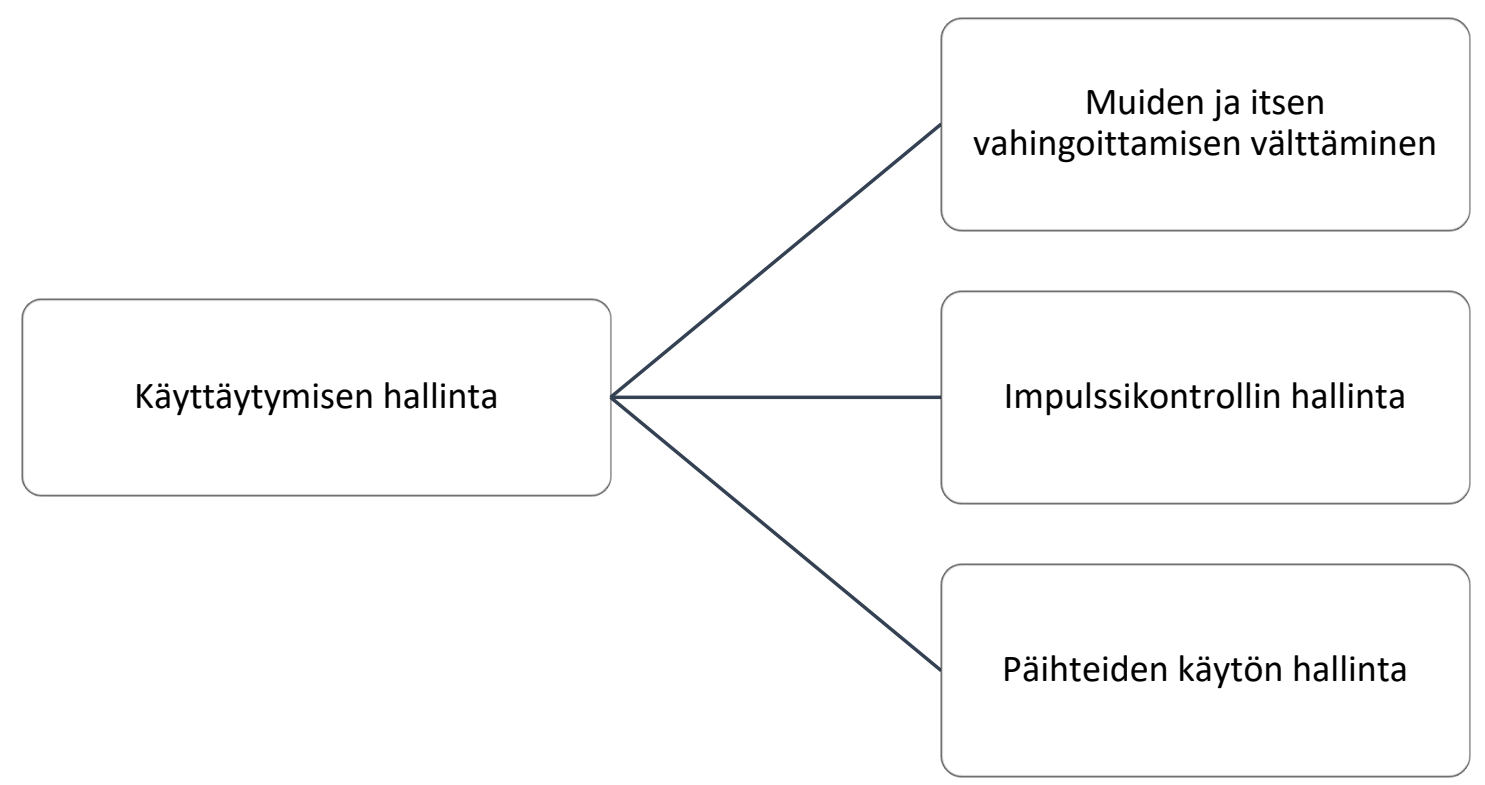

Kuvio 5. Käyttäytymisen hallintaan liittyvien tavoitteiden ryhmä ja alaryhmät

Päihteiden käyttöön liittyvissä tavoitteissa oli vaihtelua kokonaan kieltäytymisestä alkoholin kohtuukäyttöön (ks. kuvio 5.). Tässä alatavoiteryhmässä näkyi kuntoutuksen 
eteneminen: Aluksi aineistossa tavoitteena oli, että kuntoutuja pyrkisi alkoholista pidättäytymiseen, mutta kuntoutuja ei ollut välttämättä tähän motivoitunut. Kuntoutuksen edetessä kuntoutujan motivaatio päihteettömyyteen saattoi kasvaa esimerkiksi: "Saada päihteiden käyttö hallintaan, vieläkin paremmin". Tupakoinnin lopettamiseen tai vähentämiseen liittyviä tavoitteita esiintyi aineistossa vähemmän. Muiden päihteiden käyttöön liittyviä tavoitteita ei aineistossa esiintynyt.

\subsection{Sosiaalinen osallisuus}

Tässä tutkimuksessa sosiaaliseen osallisuuteen liittyvillä tavoitteilla tarkoitetaan yksilön mahdollisuutta osallistua sosiaalisiin ympäristöihin: ympäröivään yhteiskuntaan, sen rakenteisiin sekä läheisiin sosiaalisiin suhteisiin kuten perheeseen, ystävyyssuhteisiin ja parisuhteeseen (ks. kuvio 6.). Keskeisenä osana tätä pääkategoriaa on työ ja opiskelu, joihin liittyvät tavoitteet lisääntyivät kuntoutuksen edetessä.

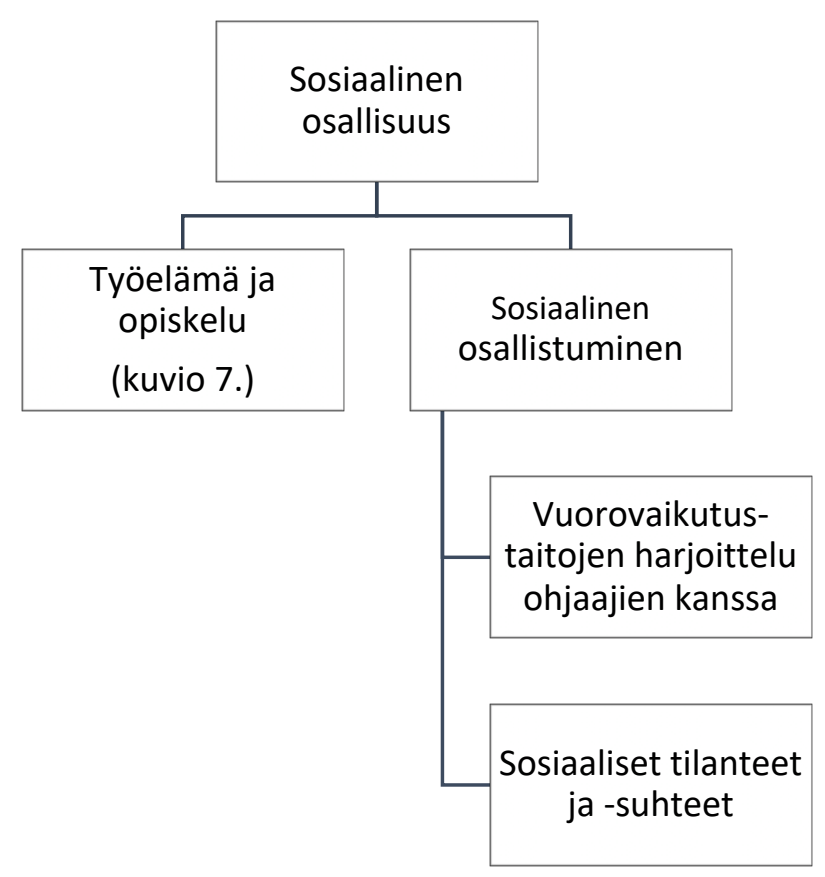

Kuvio 6. Pääkategoria sosiaalinen osallisuus 
Sosiaalisen osallistumisen osalta kuntoutujien tavoitteissa oli nähtävissä kaksi alatavoite-ryhmää, jotka olivat vuorovaikutuksessa toistensa kanssa (ks. kuvio 6.). Vuorovaikutustaitojen harjoittelussa ohjaajien kanssa oli kysymys vuorovaikutuksesta, jossa luottamalla ohjaajien antamiin ohjeistuksiin, kannustamalla nuorta kuvaamaan ajatuksiaan sekä tunteitaan, voitiin saavuttaa parempi osallistuminen. Esimerkiksi tällaisesta tavoitteesta on: "tuettu edelleen ottamaan kuormittavat asiat puheeksi". Pyrkimyksenä siis oli, että vuorovaikutuksessa ohjaajan kanssa nuori uskaltaisi kertoa itsestään. Rekisteritiedon kirjoittajat kuvasivat nuorten kannustamista ja tukemista, jolla he osoittivat sitoutumistaan nuoreen kuntoutuksen aikana ja uskoa heidän pystyvyyteensä.

Sosiaalisiin suhteisiin ja tilanteisiin liittyviä tavoitteita esiintyi aineistossa runsaasti. Tavoitteet liittyivät harvoin varsinaiseen vuorovaikutustaitojen harjoitteluun. Pääsääntöisesti tavoitteet liittyivät sosiaalisten tilanteiden pelon vähentymiseen altistumisen kautta ja selviytymiseen uusissa tilanteissa tai ympäristöissä esimerkiksi "siedättää itseä sosiaalisissa tilanteissa (tapahtumat, reissut, ruokailut)". Toisaalta ne koskivat toimintaa vuorovaikutussuhteissa esimerkiksi parisuhteessa tai suhteessa vanhempien kanssa. Tavoitteet saattoivat koskea myös vuorovaikutussuhteiden ylläpitoa tai hankkimista "luomaan ystävyyssuhteita" (ks. kuvio 6.).

Työelämään ja opiskeluun liittyvät tavoitteet voidaan jakaa kahteen alaryhmään (ks. kuvio 7.). Opiskelemiseen liittyvät tavoitteet koskivat työharjoitteluiden suorittamista kuntoutuksessa tai avoimilla työmarkkinoilla, kirjallisten tehtävien tekemistä kuntoutuksessa ja valmistumista ammattiin "valmistua ammattiin vuoden 2018 aikana". Nämä tavoitteet korostuivat niillä kuntoutujilla, joilla opinnot olivat kesken kuntoutuksen alkaessa. Näissä tavoitteissa esiintyi muihin tavoitteisiin verrattuna enemmän ajallisia määreitä. 


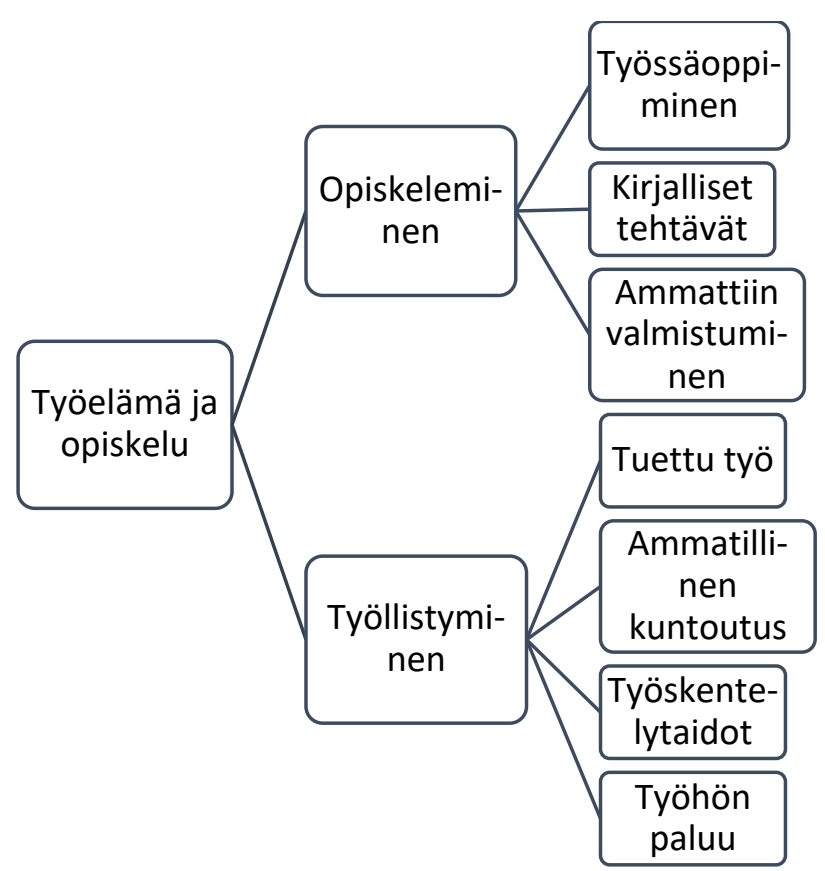

Kuvio 7.Työelämään ja opiskeluun liittyvien tavoitteiden ryhmä ja alaryhmät

Työllistymiseen liittyvät tavoitteet olivat monimuotoisempia kuin opiskeluihin liittyvät tavoitteet (ks. kuvio 7.). Ne liittyivät tuetun työllistymisen eri muotoihin: matalimman kynnyksen palvelun tarjosi kuntoutuslaitoksen sisäinen työ- ja viriketoiminta. Tavoitteet saattoivat liittyä työskentelytaitojen kehittämiseen työ- ja viriketoiminnassa tai ammatillisessa kuntoutuksessa, kuten "työaikojen noudattamisessa (liikaa tupakkataukoja)". Tavoitteet saattoivat myös koskea avotyön aloittamista tai siitä suoriutumista tai työkokeiluja esimerkiksi "avotyöpaikan etsimine". Aineistossa esiintyi myös ammatilliseen kuntoutukseen liittyviä tavoitteita, jotka koskivat Kelan ammatillisen kuntoutuksen kursseja, niille hakeutumista ja niihin osallistumista. Tavoitteet koskivat myös siirtymistä tai palaamista avoimille työmarkkinoille "paluu joltain osin työelämään”. 


\subsection{Sisäinen resilienssi}

Sisäiseen resilienssiin liittyvien tavoitteiden pääkategoriassa näkyvät yksilöllisten tekijöiden lisäksi myös yksilön kognitiiviset, psyykkiset sekä fyysiset ominaisuudet ja niiden toiminnan edistäminen. Yksilön haasteet ja ongelmat vaikeuttavat sopeutumista muuttuvissa elämäntilanteissa ja näin ollen sisäisen resilienssin syntymistä. Tähän pääkategoriaanliittyvät tavoitteet on kuvattu kuviossa 8.

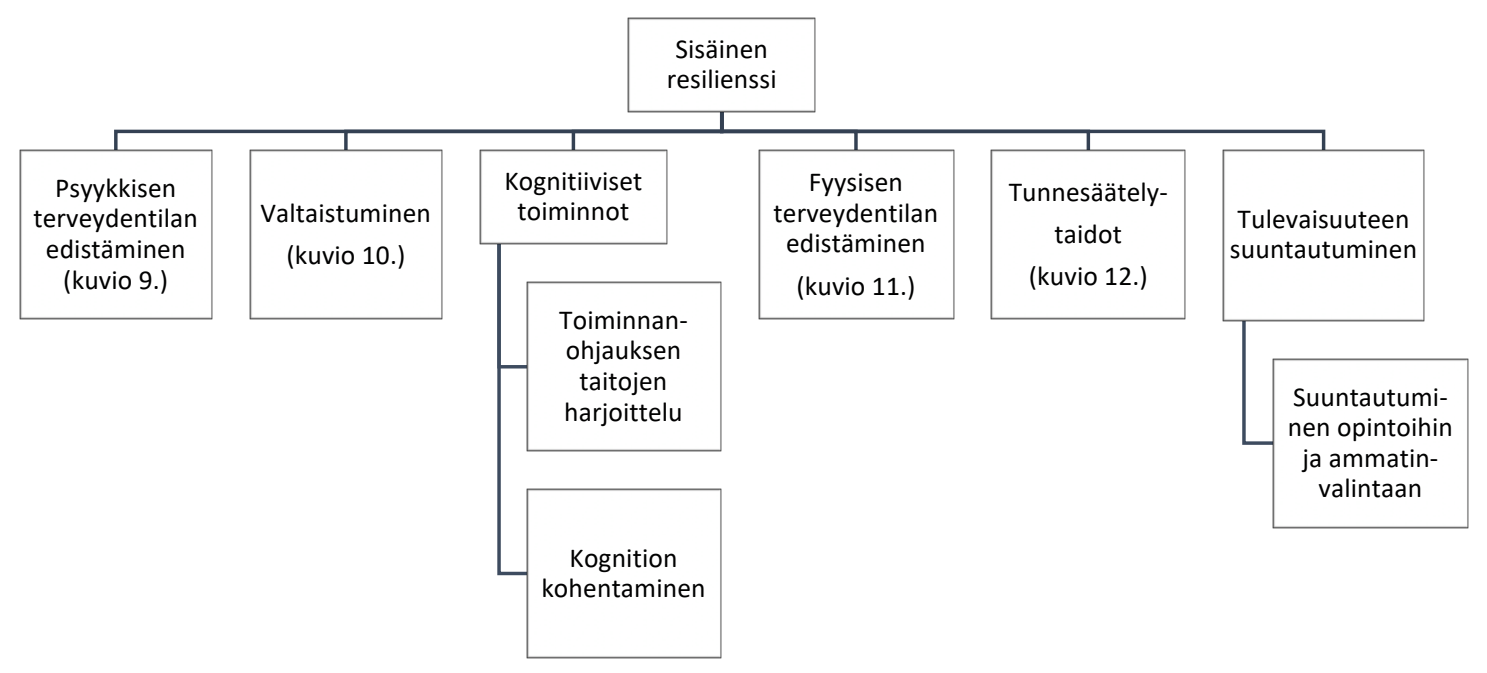

Kuvio 8. Pääkategoria Sisäinen resilienssi

Kognitiivisiin toimintoihin liittyvistä tavoitteista kognition kohentumiseen liittyvät tavoitteet koskivat tarkkaavuuden, muistin tai keskittymiskyvyn parantumista "haasteet kognitiivisia kykyjä vaativissa tilanteissa ovat nousseet esille" (ks. kuvio 8.). Toiminnanohjauksen taitoihin liittyvät tavoitteet koskivat toimintamallien käyttöönottoa, toiminnan suunnittelua, vaiheistamista, aloittamista ja lopettamista. Esimerkki toiminnanohjauksen taitoihin liittyvästä tavoitteesta on "tavoitteiksi asetettu toimin- 
nan aloittamiseen, suunnitteluun ja toteuttamiseen liittyviä asioita". Tämän alaryhmän tavoitteita oli erityisesti psykoosisairauksia sairastavilla henkilöillä, kuntoutujilla, joilla oli neuropsykiatrinen oireyhtymä ja tutkittavilla, joilla oli heikentyneet kognitiiviset valmiudet.

Tulevaisuuteen suuntautumiseen liittyvissä tavoitteissa näyttäytyi ihmisen tarve ylläpitää toivoa tulevaisuudesta, jotta jaksaa työskennellä jonkin asian eteen tässä hetkessä (ks.kuvio 8.). Aineistossa näyttäytyi ohjaajien nuorelle tarjoama tuki, jotta hän uskaltaisi haaveilla, toivoa ja unelmoida tulevaisuudesta "Pyritty herättelemään tulevaisuuteen liittyviä ajatuksia". Tulevaisuuteen suuntautumiseen liittyvissä tavoitteissa oli nähtävissä omana alaryhmänään opintoihin ja ammatinvalintaan liittyvät tavoitteet, jotka koskivat ajatuksia tulevasta ammatista ja siihen liittyvistä opinnoista "opiskelu-ja ammatinvalinnan asiat ovat seuraavat asiat, joita aletaan käsittelemään".

Psyykkisen terveyden edistämiseen liittyviä tavoitteita oli kaikilla tutkittavilla (ks. kuvio 9.). Alaryhmän sisälle kuului passiivista odottamista, että kuntoutus, aika tai muu tekijä kohentaisi psyykkistä vointia esimerkiksi "Lyhyen ajan tavoitteena voinnin tasaantuminen". Asumiskuntoutuksen alkuarviointijaksolla tavoitteena oli myös psyykkisen voinnin arviointi ammattilaisten toimesta. Toisaalta psyykkiseen vointiin liittyvien tavoitteiden alaryhmässä oli nähtävissä keinoja, joilla voidaan vaikuttaa psyykkiseen vointiin. Psykoedukaatioon liittyvillä tavoitteilla pyrittiin nuoren tietotason lisääntymiseen omasta sairaudestaan "työskentely sairauden parissa on voinut jatkua omaohjaustyöskentelyssä" ja se oli selkeästi kytköksissä oireiden hallintaan. Oireiden tunnistaminen mahdollistui lisääntyneen tiedon myötä, jolloin oireita pystyi hallitsemaan. Oireiden hallintaan liittyvien tavoitteiden alaryhmässä oli eri sairauksien oireiden hallintaan liittyviä tavoitteita, kuten psykoosioireiden hallintaan liittyviä tavoitteita. Tavoitteet saattoivat liittyä myös konkreettisten välineiden käyttöön oireidenhallinnassa esimerkiksi "oireenhallinnankortti, jota voi hyödyntää yksin ollessaan ahdistuksen kasvaessa". 


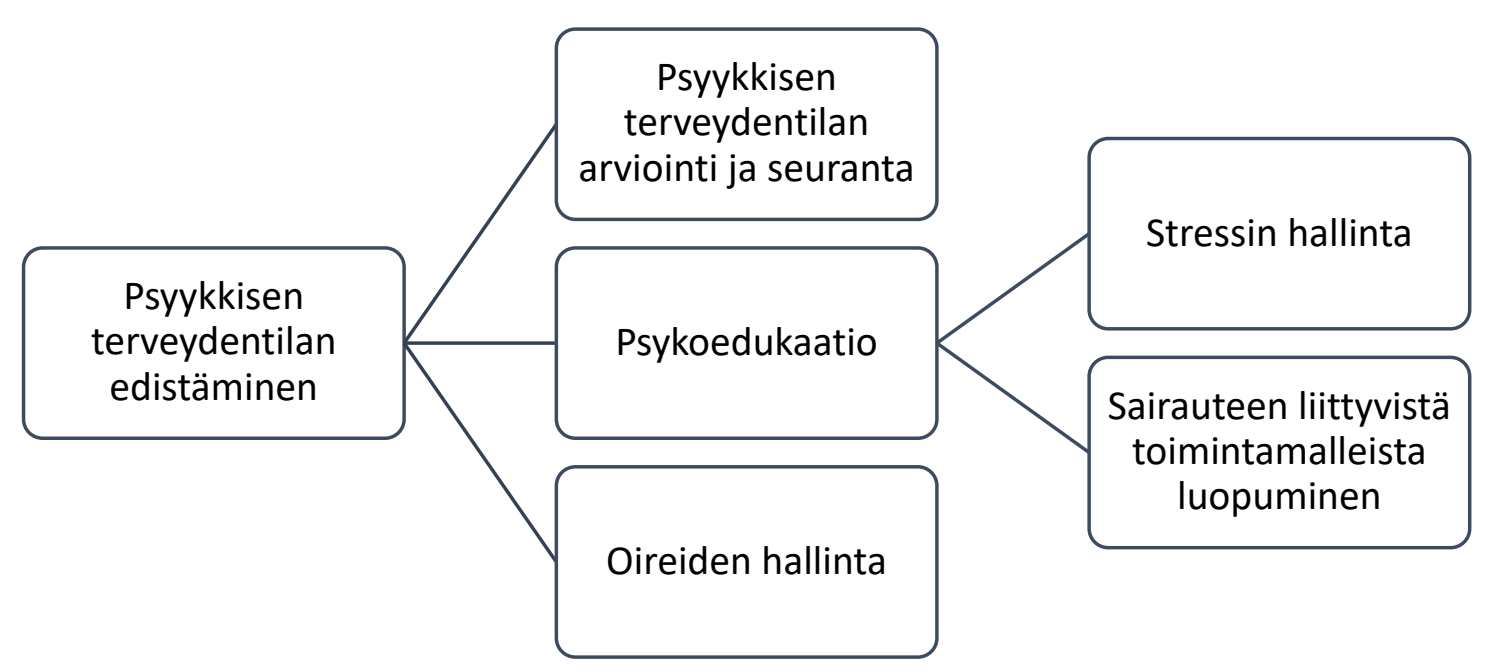

Kuvio 9. Psyykkiseen terveydentilaan liittyvien tavoitteiden ryhmä ja alaryhmät

Psyykkisten sairauksien luonne tuli esiin tavoitteissa siten, että voinnin heikentyessä tai oireiden lisääntyessä kuntoutusjakson aikana reagoitiin tavoittelemalla oireiden ja stressinhallinnan harjoittelua. Psykoedukaation alle kuuluivat myös stressinhallintaan liittyvät tavoitteet, kuten on nähtävissä kuviossa 9. Stressiä aiheuttivat muun muassa taloudelliset vaikeudet, sosiaaliset suhteet ja muutokset elämäntilanteissa, kuten avotyön aloittaminen. Toisaalta pyrittiin oppimaan myös pois sairauteen kuuluvista negatiivisista toimintamalleista "pyrkii luopumaan vanhoista toimintamalleistaan". Luovuttaessa sairauteen kuuluvista toimintamalleista vahvistuivat yksilön toimintakykyiset puolet.

Valtaistumiseen liittyviä tavoitteita kuvasivat vahvistuminen, motivoituminen, hallinta ja vastuu (ks. kuvio 10.). Itsetunnon vahvistumiseen liittyvät tavoitteet olivat keskeisessä osassa kuntoutuksessa. Omana alatavoiteryhmänään olikin nähtävissä onnistumisen kokemuksien saavuttamiseen liittyvät tavoitteet. Lisäksi omana alaryhmänään olivat yksilöllisten voimavarojen löytämiseen liittyvät tavoitteet "Alkanut ryhmän myötä löytämään omia voimavaroja tuottavia asioita." Näihin tavoitteisiin 
pyrittiin erityisesti vapaa-ajan toiminnoilla, ryhmätoiminnalla ja työ- ja viriketoiminnalla.

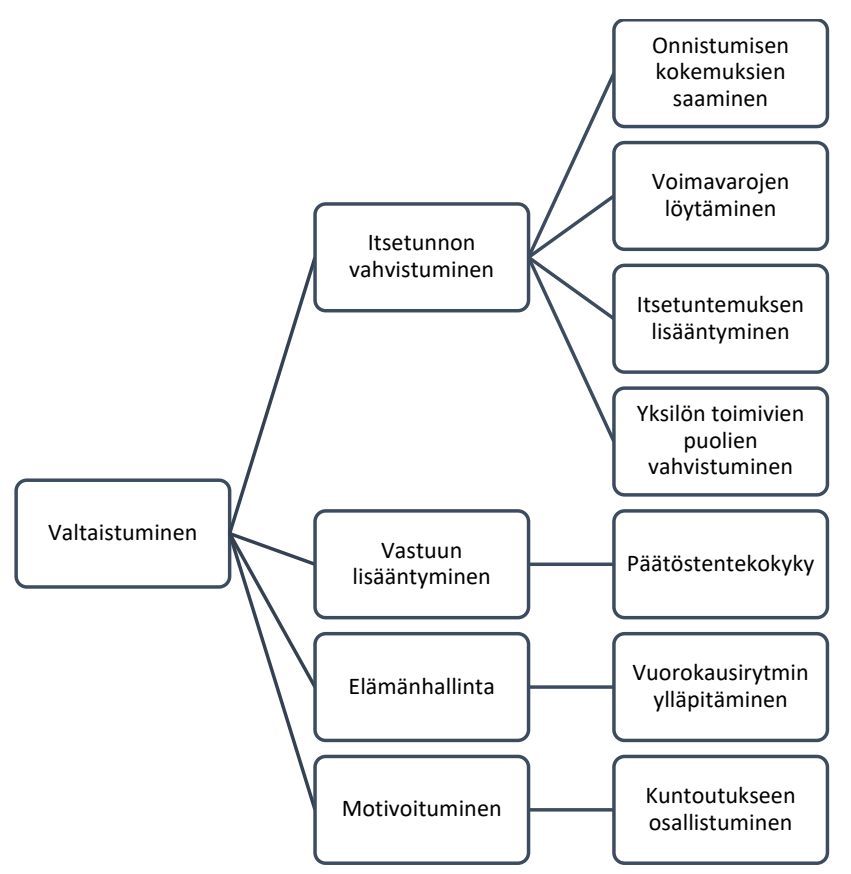

Kuvio 10. Valtaistumiseen liittyvien tavoitteiden ryhmä ja alaryhmät

Itsetuntemuksen lisääntymiseen tähtäävillä tavoitteilla pyrittiin siihen, että tutkittava oppisi tuntemaan itsensä: omat vahvuutensa, heikkoutensa, mielenkiinnonkohteensa ja niin edelleen (ks. kuvio 10.). Esimerkiksi tällaisesta tavoitteesta oli "herkästi vähättelee itseään ja omia taitojaan". Yksilön toimivien puolien vahvistamiseen liittyvissä tavoitteissa kuvattiin ikätasoisten toiminnallisten roolien omaksumista nuoren omiksi toimintamalleiksi ja osaksi pystyvyysodotuksiaan. Tällöin mahdollistui nuoren aiemman kokemuksen muutos, ettei hän sairautensa vuoksi kykenisi toiminnallisista rooleistaan suoriutumaan. Esimerkiksi "sairaus jää yhä enemmän taka-alalle" ja "nuoren aikuisten roolien ottamisesta". Yllä mainittujen ominaisuuksien vahvistuessa pyrittiin kuntoutujalle lisäämään vastuuta päätöksistään ja sitä kautta omasta elämästään. Esimerkiksi "Tuetaan päätöksenteossa" ja "vastuunottamisen lisääntyminen". 
Elämänhallintaan liittyvät tavoitteet koskivat elämän- ja arjenhallinnan kohentumista. Näitä tavoitteita tukivat vuorokausirytmin ylläpitämiseen liittyvät tavoitteet. Vuorokausirytmin ylläpitämiseen liittyvät tavoitteet koskivat useimmiten aamuheräämisiä: "harjoittelee omatoimista heräämistä kuntoutumiskodin puolella". Aineistossa esiintyi myös univaikeuksiin liittyviä tavoitteita, jotka koskivat vaikeutta nukkua yleisesti ottaen, heräilemistä ja painajaisia. Tällöin tavoiteltiin univaikeuksien helpottumista. Motivoitumiseen liittyvät tavoitteet koskivat tässä nimenomaan kuntoutukseen osallistumista ja sitä kautta tavoitteiden saavuttamista (ks. kuvio 10).

Fyysisen terveydentilan edistämiseen liittyvät tavoitteet koskivat terveydentilan tutkimista "uniapnea jota olisi syytä nyt tutkia", toisaalta todettujen sairauksien, kuten diabeteksen hoitoon kannustamista ja tukemista. Eniten aineistossa esiintyi terveellisiin elämäntapoihin liittyviä tavoitteita esimerkiksi "Painotettu myös riittävän terveellisen ravinnon ja liikunnan...". Tämä ryhmä ja sen alaryhmät on esitetty kuviossa 11.

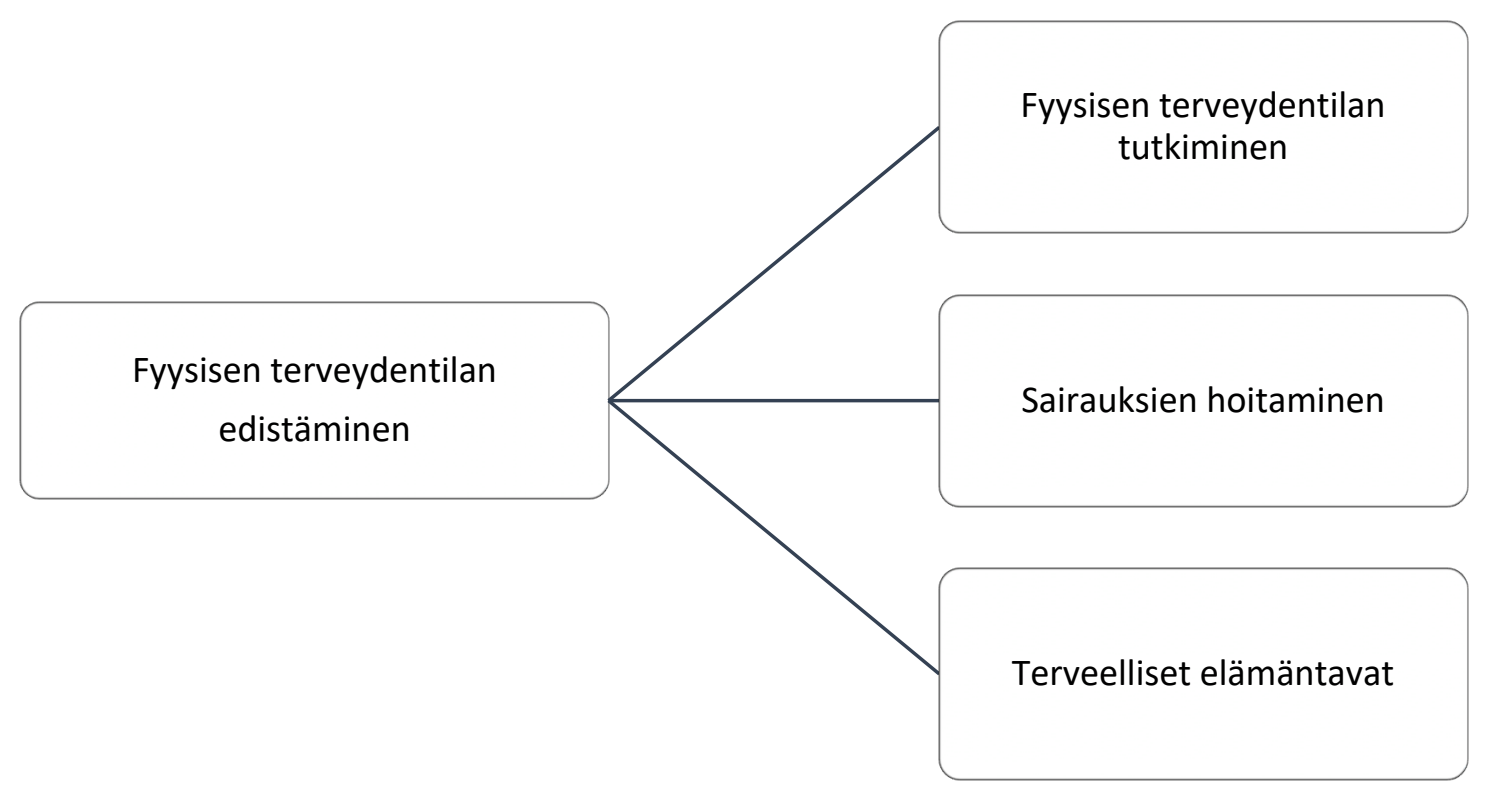

Kuvio 11. Fyysisen terveydentilan edistämiseen liittyvien tavoitteiden ryhmä ja alaryhmät 
Tunnesäätelytaitoihin liittyviä tavoitteita oli nähtävissä aineistossa enemmän lähempänä nykypäivää. Tunteiden tunnistamiseen liittyvät tavoitteet liittyivät yksilön kykyyn tunnistaa vallitsevia tunnetiloja. Ne olivat suorassa yhteydessä tavoiteryhmiin, joilla pyrittiin kehittämään tunteiden ilmaisua ja sanoittamista ja toisaalta säätelyä ja hallintaa. Tunteiden tunnistaminen mahdollisti kahta muuta esimerkiksi "Tunteiden tunnistaminen oppiminen". Tunteiden sanoittamista harjoiteltiin luottamuksellisessa vuorovaikutussuhteessa ohjaajan kanssa, yleisimmin omaohjauskeskusteluissa. Tunteiden hallinnan ja säätelyn osalta aineistossa esiintyi yleisiä tunteiden säätelyyn liittyviä tavoitteita "tunteiden säätelyn taitojen kehittyminen" ja yksittäisten tunteiden säätelyyn liittyviä tavoitteita "vihan hallinta edelleen hankalaa" (ks. kuvio 12.).

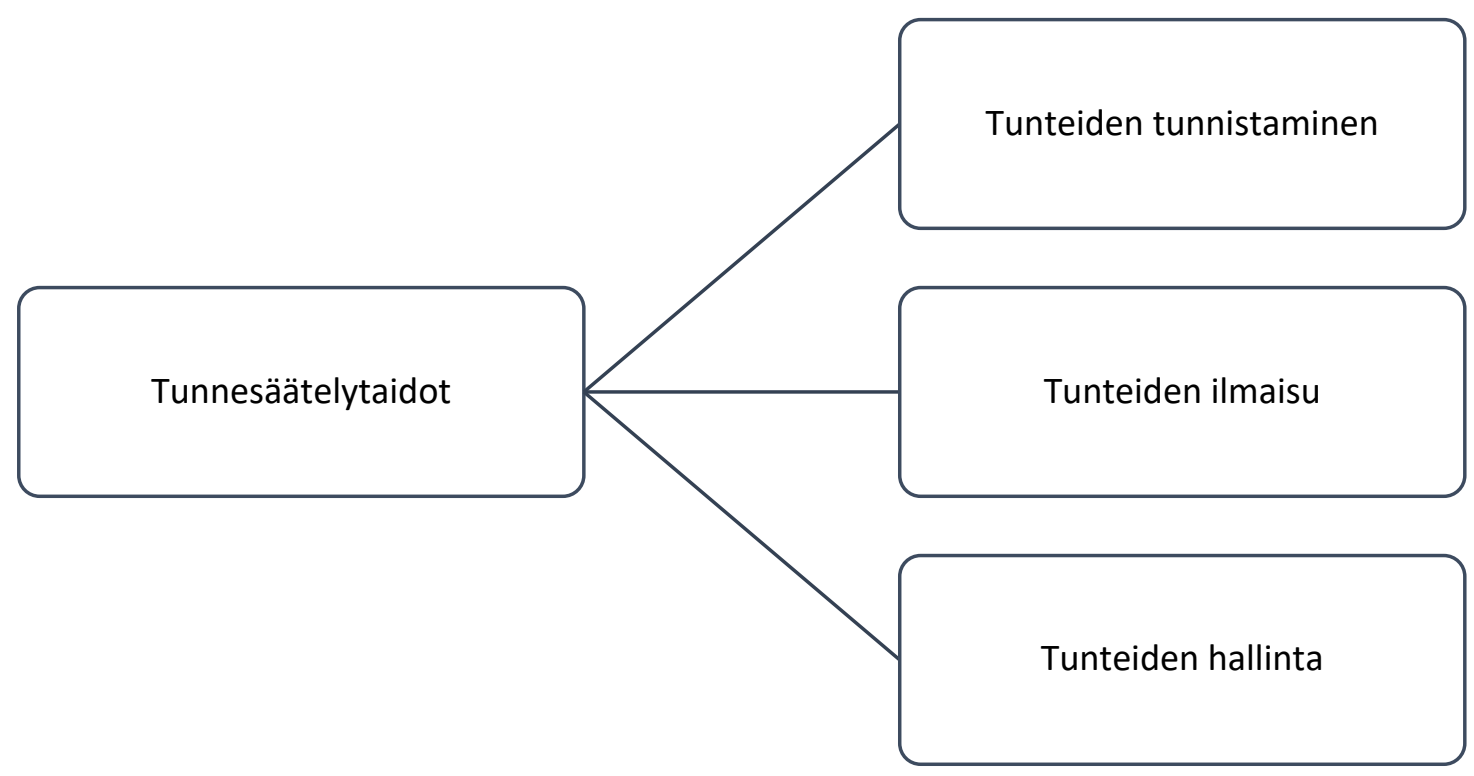

Kuvio 12. Tunnesäätelytaitoihin liittyvien tavoitteiden ryhmä ja alaryhmät 


\section{Pohdinta}

\subsection{Tulosten tarkastelu}

Nuorten mielenterveyskuntoutuksen tavoitteiden asettelussa on tärkeä huomioida nuoruuden kehitystehtävät sekä ammattilaisen ja nuoren välinen vuorovaikutussuhde. Nämä kaksi ilmiötä näkyivät tämän tutkimuksen kolmessa tavoitteiden pääkategoriassa: ikätasoisissa toiminnallisissa rooleissa, sosiaalisessa osallisuudessa sekä sisäisessä resilienssissä. Ikätasoisten toiminnallisten roolien pääkategoria kuvasi yksilön kykyä toimia ikätasoisten kehitystehtäviensä mukaisesti ja henkilökohtaisia tavoitteitansa kohti. Sosiaalisen osallisuuden pääkategoria kuvasi yksilön osallisuutta yhteisöihin ja yhteiskuntaan. Tähän vaadittiin yksilöltä sosiaalisia taitoja, joita harjoiteltiin ohjaajien kanssa. Sisäisen resilienssin pääkategoriassa esiintyi henkilökohtaisia ominaisuuksia, joita yksilö pystyi hyödyntämään vaativissa tilanteissa esimerkiksi hyvä itsetuntemus. Tämän lisäksi pääkategorian alaryhmät sisälsivät kehon kognitiiviset, psyykkiset sekä fyysiset rakenteet ja niiden toiminnan edistämisen

Pääkategorioiden tavoiteryhmät käsittelivät kokonaisvaltaisesti yksilön toimintakykyä. Esimerkiksi ICF-viitekehykseen peilaten tavoiteluokista oli löydettävissä kaikki toimintakyvyn osa-alueet. ICF-viitekehyksessä ympäristö on myös yksi toimintakyvyn osa-alue (ICF-luokitus 2016), tässä analyysissä ympäristöön liittyvät tavoitteet jäivät pieneen rooliin ja niitä oli vain muutamalla tutkittavalla. Myös muissa tutkimuksissa on löydetty vastaavia tavoiteryhmiä, muttei näin kokonaisvaltaisesti. Autereen ja kollegoiden $(2009,25)$ mukaan hoitotyön tavoitteet sisälsivät potilaan psyykkisen terveyteen, tunteiden- ja oireidenhallintaan, sosiaalisiin taitoihin ja suhteisiin sekä hoitotyön suunnitteluun liittyviä asioita. Tämän tutkimuksen pääkategorioissa esiintyy saman tyyppisiä asioita, kuten oireidenhallintaa, tunnesäätelyä sekä vuorovaikutustaitojen harjoittelua. Sen sijaan Autereen ja muiden $(2009,25)$ tutkimuksessa ei ole tunnistettu esimerkiksi työelämään ja opiskeluun tai valtaistumiseen liittyviä asioita. Tämä voi johtua siitä, että kyseinen opinnäytetyö on toteutettu sairaalaympäristössä (Autere ym. 2009, 25), kun taas tämä tutkimus kuntoutusyksikössä.

Toisessa suomalaisessa tutkimuksessa nuorilla esiintyi opiskeluun, terveyteen ja toimintakykyyn, ihmissuhteisiin, harrastuksiin ja työelämään liittyviä tavoitteita. Tämä 
tutkimus oli toteutettu Kelan vaikeavammaisten lääkinnälliseen kuntoutukseen osallistuneille nuorille. (Martin 2016, 118-121.) Martinin (2016) tutkimuksen tulokset erosivat tästä tutkimuksesta siten, ettei niissä tunnistettu sisäisen resilienssin pääkategoriaan liittyvistä tavoitteista kuin terveys. Autereen ja kollegoiden (2009) tutkimuksen lisäksi Haskell, Graham, Bernards, Flynn \& Wells (2016, 6-11) ovat tutkimuksessaan tunnistaneet, että hakeutuessaan palveluiden piiriin mielenterveyskuntoutujat tavoittelevat muun muassa psykoedukaatiota ja parempaa oireiden hallintaa.

Tässä tutkimuksessa sosiaalinen osallisuus oli yksi osa-alue mielenterveyskuntoutuksen tavoitteiden asettelussa. Sosiaalisen osallisuuden tavoittelu on kuitenkin joidenkin muiden tutkimusten mukaan korostunut mielenterveyskuntoutuksen tavoitteiden asettelussa (ks. Shadmi ym. 2017, 1313; Svedberg ym. 2014, 404-405). Tästä näkökulmasta on hyvä tarkastella, että johtuuko osallisuuteen ja erityisesti työhön liittyvien tavoitteiden korostuminen kuntoutuksen maksajan toiveista kuntoutuksen tavoitteisiin liittyen. Suomessa Kela on kuntoutuksen pääasiallinen järjestä ja rahoittaja kuntoutusetuuksista ja kuntoutusrahaetuuksista annetun lain nojalla (Kuntoutuksen uudistamiskomitea 2017, 19). Kela määrittää kuntoutuksen pääasialliseksi tavoitteeksi työ-, opiskelu- ja toimintakyvyn palauttamisen tai ylläpitämisen työkyvyn palauttamiseksi tai säilyttämiseksi (Kelan kuntoutuspalvelut 2019). Voidaan pohtia, onko Suomalaisessa järjestelmässä tavoitteiden pääasiallinen määrittäjä maksaja vai kuntoutuja itse.

Kuntoutuksen tavoitteiden tulisi keskittyä ennen kaikkea uusien taitojen hankkimiseen tai aiempien taitojen palauttamiseen. Tavoitteena ei pitäisi niinkään olla oireiden poistuminen. (Anthonyt \& Farkas 2009, 17.) Myös laajennettu tavoitteiden saavuttaminen on mahdollista. Tällä tarkoitetaan sitä, että saavuttaessaan jonkin tavoitteen nuori saavuttaa enemmän kuin yksittäisen taidon. (Lindström ym. 2013, 732736.) Tämän tutkimuksen pääkategorioista kaikissa oli mukana uusien taitojen opettelua ja laajennettua tavoitteiden saavuttamista. Uusien taitojen opettelun korostuminen on luontevaa, koska tutkimuksen kohderyhmänä olivat nuoret. Ikätasoiset toiminnalliset roolit pääkategoriassa se näkyi esimerkiksi taloudenhallinnan ja päivittäisten toimintojen harjoitteluna. Aiemman tutkimuksen mukaan taloudenhallinta mahdollistaa muiden tavoitteiden parempaa saavuttamista (Elbogen, Tiegreen, Vaughan \& Bradford 2011, 223). Sosiaalisen osallisuuden pääkategoriaan liittyi opiskelu- ja 
työskentelytaitojen harjoittelua. Sisäisen resilienssin pääkategoriaan esimerkiksi tunnesäätelytaitojen harjoittelua. Laajennettu tavoitteiden saavuttaminen näkyi esimerkiksi sisäisen resilienssin vahvistumisena, joka mahdollisti muiden tavoitteiden kuten sosiaalista osallisuuden toteutumista.

Aineistossa oli nähtävissä kuntoutuksen aikana tavoitteiden muokkaaminen realistisiksi ja saavutettaviksi (ks. Silveman Nair 2003,198; Jormfeldt ym. 2014). Esimerkiksi alun perin kuntoutujan tavoitteena oli paluu avoimille työmarkkinoille, kuitenkin kuntoutuksen edetessä merkittävät kognitiiviset vajavuudet tulivat esille. Tällöin tavoitetta muokattiin "paluu työelämään, joltain osin" ja pyrkimyksenä oli avotyöpaikan löytäminen ja säilyttäminen. On todettu, että ammattilaisten ei tulisi tukea asiakkaita epärealistisiin tavoitteiden asetteluihin, vaan ennemmin opettaa heille sopeutumiskeinoja muuttuneisiin tavoitteisiin. Tärkeää on myös tukea heitä elämään epärealistisista tavoitteista luopumiseen liittyvien negatiivisten tunteiden kanssa. Kyse on myös kyvystä oppia hyväksymään oman sairauden aiheuttamat rajoitteet. (Silverman Nair 2003, 198.) Nämä ilmiöt olivat nähtävissä tavoiteryhmissä psykoedukaatioon liittyvät tavoitteet sekä oireiden hallintaan liittyvät tavoitteet.

Rekisteriaineistossa kirjoittajat tukivat nuoria toimimaan ikätasoisesti yhteiskunnan jäseninä. Resilienssin pääkategoriassa valtaistumisen tavoiteryhmässä esiintyi yksilön toimivien puolien vahvistamiseen liittyviä tavoitteita. Lisäksi psyykkisen terveydentilan edistämisen alta tunnistettiin tarve luopua sairauteen liittyvistä toimintamalleista. Myös muissa tutkimuksissa on tunnistettu mielenterveyskuntoutujien kaipuu normaaliuteen (Haskell ym. 2016, 6-11; McGuire, Lysaker \& Wasmuth 2015, 349). Normaaliuden tukeminen voi mahdollistaa sosiaalista osallisuutta (ks. Haskell ym. 2016, 11).

Tässä tutkimuksessa nuoren vahvuuksien tukeminen oli nähtävissä sisäisen resilienssin pääkategoriassa valtaistumisen alatavoiteryhmässä. Mastens $(2001,234)$ korostaa, että interventioiden tavoitteiden asettelussa on tärkeää tukea yksilöiden pystyvyyttä ja korostaa vahvuuksia oireiden ja stressin hallinnan lisäksi. Jorgensen \& Rendtroff $(2017,498)$ mukaan, asiakkaiden osallistaminen kuntoutusprosessiin kohentaa sisäisen resilienssin osa-alueiden kuten minäpystyvyyden kehittymistä. Tämän tutkimuksen näkökulmasta voidaan ajatella, että sisäinen resilienssi kohentuu 
tavoitteiden saavuttamisen avulla. Tavoitteiden saavuttamisella puolestaan on merkittävä yhteys terveyteen, valtaistumiseen, elämänlaatuun sekä toimintakykyyn (Svedbreg ym. 2014, 404) ja se muovaa yksilöä kohti toimijan identiteettiä (Lindström ym. 2013, 732-738.). Toisaalta on todettu, että nuorten resilienssin lisääntymiseen voidaan vaikuttaa tehokkaimmin vaikuttamalla ulkoisiin resilienssitekijöihin (Ungarym. 2013, 360). Tämä on mahdollista erityisesti mielenterveyden häiriöiden ennaltaehkäisyssä, mutta myös mielenterveyskuntoutuksessa esimerkiksi tukemalla sosiaalista osallisuutta ja luomalla kuntoutukseen osallistujien välille yhteisöllisyyttä.

Tämän tutkimuksen pääkategorioista sosiaalisen osallisuuden alatavoiteryhmänä oli vuorovaikutustaitojen harjoittelu ohjaajien kanssa. Aineiston perusteella tunteiden tunnistamista ja oireiden hallintaa harjoiteltiin myös yhdessä ohjaajan kanssa. Jorgensen \& Rendtorff $(2017,499)$ toteavat, että kommunikaatio ammattilaisen kanssa voi olla sekä kuntoutuksen työkalu että tavoite, joka mahdollistaa jaettua ymmärrystä ja päätöksentekoa kuntoutujan tilanteesta. Tässä aineistossa ammattilaisten taholta sitoutunut pitkäjänteinen toiminta ja keskustelut toimivat nuorelle ilmaisuna siitä, että myös ammattilaiset olivat sitoutuneita edistämään nuorten tavoitteiden saavuttamista. Kuntoutujan kykyyn asettaa henkilökohtaisia tavoitteita auttaa tavoitteiden asetteluun saatu ammattilaisen tarjoama tuki. Tavoitteiden saavuttamiseen tarjotulla tuella on puolestaan positiivinen yhteys henkilökohtaiseen toipumiseen. (Moran ym. 2017, 98.)

Aineistossa on nähtävissä nuorten tarve harjoitella päätöksentekoa. Kuntoutujan vaikeus tehdä päätöksiä voi johtua näkemyksen tai päätöksentekokyvyn puutteista (Henrikson \& Jackson 2017, 12). Nuoret harjoittelevat aineiston mukaan päätösten tekemistä ensin pienempien valintojen avulla kantaen vastuun päätöksestään ammattilaisen tuella. Pietarisen (1994) mukaan, päätöksien tekeminen edellyttää kykyä harkintaan, toimintaan sekä valtaa tehdä päätöksiä. Voidaan käyttää käsitettä tilannekompetenssi, joilla viitataan edellytyksiin tehdä päätöksiä erilaisissa tilanteissa. (Pietarinen 1994, 17-21.) Väyrynen (2012) toteaa, ettei kuntoutujia saisi jättää yksin ongelmiensa kanssa. Näin kuitenkin välillä toimitaan, esimerkiksi korostaen kuntoujan autonomiaa. (Väyrynen 2012, 287). Tämä voi olla erityisen haitallista nuorten kohdalla, joiden itsenäistymiskehitys on edelleen kesken. Aineistossa oli nähtävissä, että nuoren kokemus onnistumisesta päätöksen teossa 
valtaistaa, jolloin minäpystyvyys suhteessa päätöksenteko kykyyn vahvistuu (vrt. Väyrynen 2012, 285).

Rekisteriaineistosta oli nähtävissä, että kuntoutukseen ja lääkitykseen liittyvät tavoitteet olivat selkeästi ennemmin ammattilaisten kuin kuntoutujien tavoitteita. Saman ilmiön ovat nostaneet esiin Henderson \& Jackson $(2017,12)$. Nämä tavoitteet voidaan nähdä vallitsevan yhteiskunnan tai kuntoutuslaitoksen struktuurin muodostamiksi tavoitteiksi, joilla pyritään jonkin kuntoutujan oman tavoitteen saavuttamiseen. Yllä esitetyn voi ajatella olevan jaettua päätöksentekoa (Jorgensen \& Rendtorff 2017, 497; Anthony \& Farkas 2009, 11). Jaettua päätöksentekoa on tutkittu nimenomaan suhteessa psykiatriseen lääkitykseen. Tutkimuksessa on todettu, että asiakkaat ovat sitoutuneempia jaettuun päätöksen tekoon, mikäli se on suhteessa heidän henkilökohtaiseen tavoitteeseensa. (Goscha \& Rapp 2015, 267-270.)

\subsection{Tutkimuksen eettisyys}

"Psykiatrisen kuntoutuksen vaikuttavuus"-tutkimushanke on käynyt läpi PohjoisPohjanmaan sairaanhoitopiirin eettisen toimikunnan ennakkoarvioinnin. Tutkimushankkeessa on mukana Pohjois-Pohjanmaan-sairaanhoitopiiri, Oulun yliopisto sekä Coronaria Sähäkkä Oy. (ks. Kuula 2006, 57.) Kuntoutujilta haettiin kirjallinen allekirjoitettu suostumus heidän tietojensa käyttöön tutkimuksessa (Liite 4. Lupa-asiakirja). Tässä asiakirjassa oli käyty läpi tarvittavat tiedot tutkimuksesta kuten tutkijat, heidän yhteystietonsa, tutkimuksen tavoitteet, käytettävä aineisto, tutkimusrekisteriin ja sen säilytykseen liittyvät asiat, tutkimuksen vapaaehtoisuus ja oikeus keskeyttää tutkimus. (ks. Kuula 2006, 102-108, 119).

Muodostettaessa rekisteriä asiakkaiden tiedot oli säilötty asiakirja-asetuksen asettamalla tavalla. Tiedot olivat sähköisessä muodossa ja suojattu pankkisalauksen tasoisesti. Kuntoutujien kanssa oli käyty läpi sähköiseen asiakashallintarekisteriin liittyvä rekisteriseloste ja he olivat antaneet luvan säilöä tietoa rekisteriin. (ks. Kuula 2006, 82-85.) Ennen varsinaisten tutkimuslupien lähettämistä tutkijat olivat soittaneet, lähettäneet tekstiviestin tai ottaneet yhteyttä sosiaalisen median kautta tutkittaviin. He olivat kertoneet lyhyesti tutkimuksesta, tiedustelleet heidän 
alustavaa kiinnostustaan osallistua tutkimukseen ja päivittäneet yhteystietoja. Tämä saattoi lisätä tutkittavien motivaatiota osallistua tutkimukseen. Tutkittaville lähettiin yksi kirjallinen muistutus suostumuksesta tutkimukseen (liite 5. Muistutus osallistumisesta tutkimukseen).

Tässä tutkimuksessa kuntoutujille luotiin numeraalinen tunnus ja tunnistetiedot poistettiin dokumenteista. Tutkittaviin liittyvä kirjallinen materiaali säilytetiin arkistointiohjeiden vaatimalla tavalla ja siihen oli pääsy vain tutkimusryhmällä. Sähköinen materiaali oli anonyymiä ja tämä materiaali säilytettiin tietoturvavaatimusten edellyttämällä tavalla Oulun yliopistolla. Tutkimuksessa muodostui rekisteri, jossa tutkija toimi rekisterinpitäjänä. (Soveltaen Kuula 2006, 8283,111 .) Tutkimuksen aineisto arkistoidaan Oulun yliopistolle ja siihen oli pyydetty erillinen suostumus lupa-asiakirjassa (Liite 4. Lupa-asiakirja). Nykykäytännön mukaan aineistojen arkistointia suositellaan (Kuula 2006, 219-222).

Aineisto on anonyymi, kun siitä ei ole mahdollista tunnistaa tutkittavia suorasti tai epäsuorasti (Kuula 2006, 112). Suora tunnistaminen on, esimerkiksi etu- ja sukunimeen perustuva tunnistaminen. Epäsuoralla tunnistamisella tarkoitetaan, esimerkiksi asuinpaikka ja ammatti yhdistämällä tapahtunutta tunnistamista. Tämän tutkimuksen tekijä on työskennellyt tutkittavien kanssa. Tältä osin oli mahdollista tunnistaa tutkittavia esimerkiksi jopa yksittäisten tavoitteiden perusteella. Tämä voi vaikuttaa tutkimuksen objektiivisuuteen ja luotettavuuteen. Aineiston arkaluonteisuuden kannalta tärkeintä on kuitenkin, ettei tutkijaryhmän ulkopuolinen kykene tunnistamaan henkilöitä aineistosta (Kuula 2006, 112).

Tutkimustyössä sekä opinnäytetyön loppuraportissa tutkija oli sitoutunut noudattamaan annettuja ohjeistuksia ihmistieteiden tutkimuksen arvomaailmasta ja etiikasta (esimerkiksi Norjan tutkimuseettiset ohjeet ihmistieteille, Tutkimustieteellisen neuvottelukunnan ohjeistukset, Maailman lääkäriliiton Helsingin julistus 1964). Tutkija oli työssään sitoutunut kunnioittamaan ihmisarvoa, itsemääräämisoikeutta, välttämään haittaa tutkittaville ja määrittelemään omaa rooliaan sekä motiivejaan tutkimukselle. Tutkijan kiinnostus mielenterveyteen on alkanut jo varhaisella iällä, sillä tukijan sukuhistoriassa on vakavia mielenterveyden häiriöitä. Tämä on ohjannut tutkijan halua työskennellä kyseisen kohderyhmän 
kanssa työssään ja nyttemmin tutkimuksessaan. Eettisesti tutkijan työskenteleminen tutkimusjoukon kanssa on voinut aiheuttaa objektiivisuuden puutetta aineiston analyysissä sekä tulosten esittelyssä. Toisaalta se on myös voinut auttaa tutkijaa ymmärtämään tutkimusjoukkoa jaa kohtelemaan heitä kunnioittavasti.

\subsection{Tutkimuksen luotettavuus}

Tutkijan tulee olla tietoinen omista arvoistaan ja asenteistaan ja pyrkiä siihen, etteivät ne vaikuta tutkimukseen liikaa. Tutkimuksen luotettavuutta voidaan kohentaa kriittisellä arvioinnilla. Oman toiminnan reflektointi läpi tutkimusprosessin, on keskeinen osa kriittistä arviointia. (Graneheim \& Lundman 2004, 111.) Tässä opinnäytetyön loppuraportissa on ollut tarkoituksena kuvata mahdollisimman todenmukaisesti ja rehellisesti tehdyt ratkaisut ja niiden perustelut.

Tämän tutkimuksen tekijä on työskennellyt nuorisopsykiatrisessa kuntoutuksessa ylikymmenen vuoden ajan. Hän on myös työskennellyt tutkittavien kanssa. Tämän tutkimuksen tekijän pitkä kokemus käsiteltävästä ilmiöstä saattoi auttaa ymmärtämään ilmiötä, mutta toisaalta se teki hänestä subjektiivisen omien kokemustensa kautta (ks. Eskola \& Suoranta 1998, Tutkijan asema, Arviointi luotettavuutena). Laadullisessa tutkimuksessa tutkija on ikään kuin tutkimuksen tekemisen väline (Eskola \& Suoranta 1998, Arviointi luotettavuutena). Tässä opinnäytetyössä on luotu kielellinen konstruktio tehtäessä sisällönanalyysia ja kirjoitettaessa loppuraporttia. Tämän tutkimuksen tekijä on pyrkinyt tuomaan esiin erilaisia näkökantoja, mutta toisaalta sulkenut toisia pois. (ks. Eskola \& Suoranta 1998, Tutkijan asema, Erilaiset kielikäsitykset ja puheen keskeisyys sosiaalisen todellisuuden rakentajana.)

Laadullisen tutkimuksen kohdalla aineistoa käytetään sen verran kuin nähdään tarpeelliseksi. Eskola \& Suoranta (1998, Harkinnanvarainen otanta, Aineiston kattavuus) toteavat, että harkinnanvarainen otanta on usein järkiperäisin laadullisessa tutkimuksessa eikä riittävän aineiston määrittämiseksi ole kriteereitä. On toki kysymys myös resurssien käytöstä sekä siitä, kuinka syvällisesti tutkija olisi kyennyt suurempaa aineistoa käsittelemään. Aineiston saturaatiolla tai kyllääntymisellä tarkoitetaan prosessia, jossa aineisto ikään kuin alkaa toistaa itseään eikä tutkimusongelman kannalta 
uusia sisältöyksiköitä tai ilmiöitä tule esille. (Eskola \& Suoranta 1998, Aineiston kyllääntyminen.)

Tuomi ja Sarajärvi (2018) kritisoivat kyllääntymisen käsitettä. Heidän mukaansa keskeisintä on, halutaanko tutkimuskysymyksien avulla löytää aineistosta samankaltaisuutta vai erilaisuutta. Etsittäessä samankaltaisuuksia aineisto kyllääntyy helposti, mutta etsittäessä eroavaisuuksia ei. (ks. Tuomi \& Sarajärvi 2018, 3.4.1.) Tässä tutkimuksessa oli tarkoituksena kuvailla aineistossa esiintyviä erilaisia tavoitteita. Tämän tutkimuksen tekijän käsityksen mukaan tämä onnistui 16 tutkittavan aineistolla. Esimerkkinä mainittakoon, että vastaavissa rekisteritiedon perusteella tavoitteiden asetteluun liittyvissä tutkimuksissa oli käytetty 12 henkilön (Autere ym.2009, 24) ja 33 henkilön aineistoa (Clarke ym. 2009, 297).

Laadullisen tutkimuksen luotettavuuden tarkastelussa käytettyihin käsitteisiin tulee suhtautua kriittisesti. Määrällisestä tutkimuksesta siirretyt käsitteet reliabiliteetti ja validiteetti, eivät välttämättä sovellu suoraan laadulliseen tutkimukseen. (Graneheim \& Lundman 2004, 109; Eskola \& Suoranta 1998, Laadullisen tutkimuksen arviointi.) Graneheim \& Lundman (2004) ehdottavat käytettäväksi uskottavuuden, siirrettävyyden ja käyttökelpoisuuden termejä. Uskottavuudella tarkoitetaan tutkimuksen fokusoitumista tutkimaan sitä ilmiötä, mitä oli tarkoituskin tutkia. Käytännössä tarkoitetaan tutkimusasetelmaan, tutkimuksen aineiston ja tutkittavien valintaan ja aineiston keruuseen liittyviä kysymyksiä. (Graneheim \& Lundman 2004, 109.)

Sisältöyksiköiden valinta on keskeinen osa tutkimuksen uskottavuutta. Sisältöyksikkö ei saa olla liian laaja ja sisältää useita merkityksiä eikä myöskään liian pieni. Poikkeuksena tästä voidaan pitää sitä, kun tekstissä lause tarkoittaa symbolista merkitystä. Seuraavassa lainauksessa lauseella oli symbolinen merkitys: "Tavoitteena terapiassa, että löytäisi keinoja ADHD-oireiden hallintaan”. (ks. Graneheim \& Lundman 2004, 109-110.) Tuomi \& Sarajärvi (2018) toteavat lainausten käytöstä, että ennemmin kuin ne olisivat luotettavuuden mittareita, ne ovat esimerkkejä aineistosta. Tutkijan oman tulkinnan tulee aina edeltää tai seurata lainauksen käyttöä. (Tuomi \& Sarajärvi 2018, 1.1.2.)

Toinen uskottavuuteen vaikuttava asia on yhdenmukaisuuksien ja erojen tunnistaminen tavoiteluokkien välillä. Tavoiteluokkien uskottavuutta tässä loppuraportissa on 
pyritty osoittamaan lainauksilla tekstistä sekä löytämällä yhdenmukaisuuksia aiemmasta tutkimuksesta. Nämä keinot lisäävät myös tutkimuksen tulosten siirrettävyyttä. (ks. Graneheim \& Lundman 2004, 109-110.) Eskola \& Suoranta (1998, Arviointi luotettavuutena) toteavat, että sosiaalisen todellisuuden luonteen vuoksi ilmiöiden siirtäminen on harvoin, jos koskaan mahdollista.

Rekisteriaineisto oli tekstiä ja tekstin voidaan ajatella sisältävän useita merkityksiä, joten tekstin käsittelyyn sisältyy aina jonkin verran tulkintaa. Tämä on keskeistä, kun pohditaan laadullisen aineiston analyysin luotettavuutta. (Graneheim \& Lundman 2004, 105.) Esimerkiksi "ottaa vastuuta lääkityksestä" -sisältöyksikkö voitaisiin luokitella vastuun lisääntymisen tai lääkitykseen liittyvien tavoitteiden alle. Analyysissä se oli sisällytetty kuuluvan vastuun lisääntymiseen liittyviin tavoitteisiin. Yksi tavoite saattoi kuulua aina vain yhden tavoiteluokan alle (ks. Graneheim \& Lundman 2004, 107; Cavanagh 1997, 10).

Laadullisen tutkimuksen luotettavuudessa käyttökelpoisuudella tarkoitetaan aineiston ajallista muuttumattomuutta ja tutkijan tekemiä muutoksia analyysin aikana. Aineiston keruun ja analyysin kestäessä pitkään on mahdollista, että analysointitapa muuttuu tai vaihtelee. Toisaalta aineiston lisääntyessä katsantokannat asioihin voivat muuttua. (Graneheim \& Lundman 2004, 110.) Tutkija on pyrkinyt loppuraportissa esittämään muutokset, joita on tehnyt analyysin aikana.

\subsection{Johtopäätökset}

Tämän tutkimuksen tulosten perusteella olisi tärkeä huomioida nuoren kuntoutujan ja ammattilaisen välinen vuorovaikutussuhde tavoitteiden asettelussa. Vuorovaikutussuhteen tulisi perustua yhteiseen ymmärrykseen ja tarpeen mukaiseen jaettuun päätöksentekoon. Näiden keinojen avulla vahvistetaan nuoren motivaatioita, valtaistumista ja minäpystyvyyttä, jotka tukevat nuoren kuntoutumista ja toipumista. Ammattilaisen tehtävänä työskentelyssä on ylläpitää toivoa paremmasta tulevasta (Kokko 2007, 5-7) ja ammattilaisten asenteet ovat yhteydessä kuntoutujan motivaatioon (Silverman Nair 2003, 197). Toisin sanoen nuoren edellytys sitoutua kuntoutukseen ja saavuttaa tavoitteitaan perustuu pitkälti ammattilaisen ja nuoren väliseen 
luottamussuhteeseen. (ks. Jorgensen \& Rendtorff 2017, 493; Jormfeldt ym. 2014.) Tältä kannalta ajateltuna olisikin mielenkiintoista tutkia tavoitteidenasetteluprosessia sekä ammattilaisen että kuntoutujan näkökulmasta. Erityisesti tarpeen olisi tutkia sitä, mitä elementtejä prosessin tulee sisältää, jotta saavutetaan hyvä lopputulema.

Toinen johtopäätös tämän tutkimuksen tuloksista on tavoitteiden asettelussa yksilön laajempien elämän tavoitteiden ja kehitystehtävien huomioiminen. Tämä näkyi tavoiteluokkien kokonaisvaltaisuuden lisäksi erityisesti ikätasoisten toiminnallisten roolien pääkategoriassa. Tarvittaisiinkin tutkimusta siitä, ovatko sellaiset kuntoutusohjelmat tehokkaampia, joiden tavoitteet perustuvat laajempiin elämän tavoitteisiin ja kehitystehtäviin (ks. Silverman Nair 2003, 192) verrattuna sellaisiin mielenterveydeninterventioihin, joiden tavoitteena on yksittäisten toimintakyvyn osa-alueiden kohentaminen esimerkiksi kognitiivinen kuntoutus tai lääkehoito.

Hyvän jatkotutkimusasetelman mahdollistaa Psykiatrisen kuntoutuksen vaikuttavuustutkimushankkeen tutkimusasetelma, jossa arvioidaan tavoitteiden saavuttamista kuntoutuksen päättyessä ja seuranta-ajan jälkeen. Tavoitteiden saavuttamista arvioidaan laadullisin ja määrällisin keinoin ja seuranta tapahtuu kyselyn avulla. (Moilanen, Jääskeläinen \& Tolonen 2018, 2-3.) Mielenkiintoinen jatkotutkimusaihe on myös tässä tutkimuksessa saatujen tuloksien tutkiminen laajemmassa aineistossa, esimerkiksi määrällisin keinoin (ks. Eskola \& Suoranta 1998, Luotettavuus ikkunana todellisuuteen). Tärkeää tietoa tarjoaisi myös tutkimus nuoren pystyvyysodotuksien vaikutuksesta kuntoutumiseen (ks. Salminen 2017) sekä minäpystyvyyden suhteesta tavoitteiden asetteluun. Tämän tutkimusten tulosten perusteella mielenkiintoinen jatkotutkimusaihe olisi myös kuntoutuksen tavoitteiden suhde valtaistumisen, toipumisen ja kuntoutumisen käsitteisiin. 


\section{Lähteet}

Aaltonen, S., Berg, P. \& Ikäheimo, S. 2015. Nuoret luukulla -Kolme näkökulmaa syrjäytymiseen ja nuorten asemaan palvelujärjestelmässä. Terveyden ja hyvinvoinnin laitos. Nuorisotutkimusseura ry. Tutkimuksesta tiiviisti 3. Viitattu 19.6.2018. http://www.julkari.fi/bitstream/handle/10024/125695/URN_ISBN_978-952-302-4427.pdf? sequence $=1$ \&isAllowed $=y$.

Aalto-Setälä, T. \& Marttunen, M. 2007. Nuoren psyykkinen oireilu - häiriö vai normaalia kehitysta? Duodecim 123, 207-213.

Alanko, A. \& Hellman, M. 2017. Service Users and Experts in Finnish Mental Health Care Planning: Three Phases of Expansion and Inclusion. Sosiologia 4, 361-376.

Alanko, T., Karhula, M. Piirainen, A. Kröger, T. \& Nikander, R. 2017. Kuntoutujan osallistaminen tavoitteenasettamisprosessiin ja tavoitteiden saavuttamisen arvointiin. Loppuraportti. Kelan tutkimus. Kelan työpapereita 113. Viitattu 13.1.2017. https://helda.helsinki.fi/bitstream/handle/10138/175226/Tyopapereita113.pdf?sequ ence $=1$.

Anthony, W.A. \& Farkas, M.D. 2009. A Primer on the Psychiatric Rehabilitation Process. Boston: Boston University Center for Psychiatric Rehabiliation.

Arnett, J.J. 2000. Emerging Adulthood. The Theory of Development From the Late Teens Trough The Twenties. American Psychologist 55, 5, 469-480.

Autere, K., Paavola, M., Selander, M. \& Kilkku, N. 2009. Tavoitteet esiin hoitotyön kirjaamisessa. Sairaanhoitaja 82, 2, 24-25.

Bandura, A. 2000. Exercise of Human Agency Through Collective Efficacy. Current Diractions in Psychological Sience 9, 3, 75-78.

Bandura, A. 2001. Social Cognitive Thepry: An Agentic Perspective. Annual Review of Psychology 52, 1, 1-26.

Bandura, A. 2006. Toward a Psychology of Human Agency. Perspectives on Psychological Sience 1, 2, 164-180.

Bowend'Eerdt, T.J.H. Botell; R.E. \& Wade, D.T. 2009. Writing SMART rehabilitation goals and achieving attainment scaling: a practical guide. Clinical Rehabilitation 23, 352-361.

Browne, J. Penn, D.L., Meyr-Kalos, P.S., Mueser, K.T., Estroff, S.E., Brunette, M.F., Correll, C.U., Robinson, J., Rosenheck, R.A., Schooler, N., Robinson, D.G., Addington, J. Marcy, P. \& Kane, J.M. 2017. Psychological well-being and mental health recovery in the NIMH RAISE early treatment program. Schizophrenia Research 185, 167-172.

Bowie, C.R., Crossman, M., Gupta, M. Holshausen, K. \& Best, M.W. 2017. ActionBased Cognitive Remedation for Individuals With Serious Mental Illness: Effects of Real-World Simulationsa and Goal Setting on Functional and Vocational Outcomes. Psychiatric Rehabilitation Journal 40, 1, 53-60. 
Cairns, A., Kavanagh, D., Dark, F. \& McPhail, S.M. 2015. Setting measurable goals with young people: Qualitative feedback form Goal Attainment Scale in youth mental health. Brittish Journal of Occupational Therapy 78, 4, 253-259.

Carl, E., Stein, A., Levihn-Coon, A., Pogue, J.R., Rothbaum, B., Emmelkamp, P., Asmundson, G.J.G., Carlbring, P. \& Powers, M.B. In press. Virtual reality exposure therapy for anxiety and related disorders: A meta-analysis of randomized controlled trials. Journal of Anxiety Disorders. Viitattu 22.3.2019.

https://www.ncbi.nlm.nih.gov/pmc/articles/PMC4786550/.

Cavanagh, S. 1997. Content analysis: consepts, methods and applications. Nurse Reasearcher 4, 3, 5-16.

Clarke, S.P., Crowe, T.P., Oades, I.G. \& Deane, F.P. 2009. Do Goal-Setting Interventions Improve the Quality of Goals in Mental Health Services? Psychiatric Rehabilitation Journal 32, 4, 292-299.

Depressio. Käypä hoito -suositus. 2016. Suomalaisen lääkäriseura Duodecimin ja Suomen Psykiatri yhdistyksen asettama työryhmä. Helsinki: Suomalainen lääkäriseura Duodecim. Viitattu 13.3.2019. http://www.kaypahoito.fi/web/kh/suositukset/suositus?id=hoi50023.

Dray, J., Bowman, J., Freund, M., Campbell, E., Wolfenden, L., Hodder, R.K. \& Wiggers, J. 2014. Improving adolescent mental health and resilienc e through a resilience-based intervention in schools: study protocol for a randomised controlled trial. Viitattu 9.1.2019.

https://trialsjournal.biomedcentral.com/articles/10.1186/1745-6215-15-289.

Gee, B., Notley, C., Byrne, R. Clarke, R., Hodgekins, J., French, P. \& Fowler, D. 2016. Young people`s experienves of Social Recovery Cognitive Behavioural Therapy and Treatment as usual in the Prodigy trial. Early Intervention in Psychiatry, 1-7.

Goscha, R. \& Rapp, C. 2015. Exploring the Experiences of Client Involvement in Medication Decisions Using a Shared Decision Making Model: Results of a Qualitative Study. Community Mental Health Journal 51, 267-274.

Graneheim, U.H. \& Lundman, B. 2004. Qualitative content analysis in nursing research: concepts, procedures and measures to achieve trustworthiness. Nurse Education Today 24, 105-112.

Gyllenberg, D., Marttunen, M. \& Sourander, A. 2016 Psykiatrisen hoidon tarve. Julkaisussa lastenpsykiatria ja nuorisopsykiatria. Toim. K. Kumpulainen, E. Aronen, H. Ebeling, E. Laukkanen, M. Marttunen, K. Puura \& A. Sourander. 2016. Tallinna: Duodecim, 124-128.

Eklund, M. \& Tjörnstrand, C. Psychiatric rehabilitation in community-based day centers: Motivation and satisfaction. Scandinavian Journal Of Occupational Therapy 20, 438-445.

Elbogen, E.B, Tiegreen, J., Vaughan, C. \& Bradford, D.W. 2011. Money Management, Mental Health, and Psychiatric Disability: A Recovery-Oriented Model for Improving Financial Skills. Psychiatric Rehabilitation Journal 34, 3, 223-231. 
Elo, S. \& Kyngäs, H. 2008. The qualitative content analysis process. Journal of Advanced Nursing 62, 1, 107-115.

Epävakaa persoonallisuus. Käypä hoito -suositus. 2015. Suomalaisen Lääkäriseuran Duodecimin ja Suomen Psykiatriyhdistus ry:n asettama työryhmä. Helsinki: Suomalainen lääkäriseura Duodecim. Viitattu 3.1.2019. http://www.terveysportti.fi/xmedia/hoi/hoi50064.pdf.

Eskola, J. \& Suoranta, J. 1998. Johdatus laadulliseen tutkimukseen. Tampere: Vastapaino. E-kirja.

Fowler, D., Hodgekins, J., French, P., Marshall, M., Freemantle, N., McCrone, P., Everard, L., Lavis, A., Joes,P.B., Amos, T., Singh, A., Sharma. V. \& Birchwood, M. 2018. Social recovery therapy combination with early intervention services for enhncement of social recovery in patients with first-episode psychosis (SUPERENDEN3): a singleblind, randomized controlled trial. The Lancet 5, 1, 41-50. Viitattu 9.2.2019. https://www.thelancet.com/journals/lanpsy/article/PIIS2215-0366(17)304765/fulltext.

Freeman, D., Reeve, S., Robinson, A., Ehlers,A., Clark, D., Spanlang, B. \& Slater, M. 2017. Virtual reality in the assessement, understanding, and treatment of menthal health disorders. Psychological Medicine 47, 2393-2400. Viitattu 2.1.2019.

https://www.cambridge.org/core/services/aop-cambridgecore/content/view/A786FC699B11F6A4BB02B6F99DC20237/S003329171700040Xa. $\mathrm{pdf} /$ virtual reality in the assessment understanding and treatment of mental $\mathrm{h}$ ealth disorders.pdf.

Haskell, R., Graham, K., Bernards, S., Flynn, A. \& Wells, S. 2016. Service user and family member perspectives on services for mental health, substance use/addiction, and violence: a qualitative study of their goals, experiences and recommendations. International Journal of Mental Health Systems 10, 90, 1-14. Viitattu 5.1.2019. https://ijmhs.biomedcentral.com/articles/10.1186/s13033-016-0040-3.

Henderson, P. \& Jackson, W. 2017. Recovery in mental health: examining the reality or professionals and service users. Mental Health Nursing October/November, 1114.

Hirsjävi, S. \& Hurme, H. 2008.Tutkimushaastattelu: Teemahaastattelun teoria ja käytäntö. Helsinki: Gaudeamus Helsinki University Press.

ICF-luokitus. 2016. ICF-luokitus. Terveyden ja hyvinvoinninlaitoksen verkkosivusto osio toimintakyky. Viitattu 27.6.2018: https://thl.fi/fi/web/toimintakyky/icf-luokitus.

Isola, A-M., Kaartinen, H., Leemann, L., Lääperi, R., Schneider, T., Valtari, S. \& KetoTokoi, A. 2017. Mitä osallisuus on? Osallisuuden viitekehystä rakentamassa. Terveyden ja hyvinvoinninlaitoksen työpapereita 33/2017. Viitattu 27.12.2018. https://www.julkari.fi/bitstream/handle/10024/135356/URN ISBN 978-952-302917-0.pdf?sequence=1.

Hoitotakuu nuorisopsykiatrisassa NUOTTA -projektin loppuraportti 2003. Sosiaali - ja terveysministeriön selvityksiä 2003:13. Helsinki: Sosiaali- ja terveysministeriö. Viitattu 22.3.2019. 
https://julkaisut.valtioneuvosto.fi/bitstream/handle/10024/73222/Selv200313.pdf?s equence=1\&isAllowed $=\mathrm{y}$.

Jacob, J., De Fransesco, D., Deighton, J., Law, D., Wolpert, M. \& Edbrooke-Childs, J. 2017. Goal formulation and tracking in child mental health settings: when is it more likely and is it associated with satisfaction with care? Europian Child and Adolescent Psychiatry 26, 759-770.

Joensuu, M. \& Holappa, P. 2017. Nuorten aikuisten mielenterveysperusteinen työkyvyttömyys. Seminaari esitys. Kansaneläkelaitoksen ja Terveyden ja hyvinvoinninlaitoksen seminaari "Miten tuemme nuorten mielenterveyttä ja polkuja työelämään?"Katsottavissa Youtubessa. Viitattu 4.1.2018.

https://www.youtube.com/watch?v=pjROTrVvL6U.

Jormfeldt, H., Svensson, B., Hansson, L. \& Svedberg, P. 2014. Clients`experiences of the Boston Psychiatric Rehabiliation Approach: A qualitative study. International Journal Of Qualitative Studies on Health and Well-Being. 9, 1. Viitattu 26.12.2018. https://doi.org/10.3402/qhw.v9.22916.

Jorgesen, K. \& Rendtorff, J.D. 2017. Patient participation in mental health care perspectives of healthcare professionas: an integrative review. Scandinavian journal of Caring Science, 490-501.

Järvikoski, A. 2008. Kuntoutuskäsityksen muutos ja kuntoutuksen vaikuttavuuden tutkimus. Julkaisussa vaikuttavuus muutoksessa. Toim. J. Mäkitalo, J. Turunen \& I. Vilkkumaa. Verve: Oulu.

Järvikoski, A. 2013. Monimuotoinen kuntoutus ja sen käsitteet. Sosiaali- ja terveysministeriön raportteja ja muistioita 43. Helsinki: Sosiaali- ja terveysministeriö. Viitattu 5.1.2018. http://thl32-

kk.lib.helsinki.fi/bitstream/handle/10024/114972/URN ISBN_978-952-00-3457-

3.pdf? sequence=1.

Järvikoski, A., Härkäpää, K. \& Salminen, A-L. 2015. Kuntoutuksen teoriosta ja ICFmallista. Kuntoutus 38, 2, 18-32. Viitattu 10.1.2018.

https://www.researchgate.net/publication/278673923 Kuntoutuksen teorioista ja ICF-mallista Rehabilitation theories and the ICF.

Kauppinen, S. \& Forss, A. 2008. Kasvatus- ja perheneuvonta 2007. Stakes.

Tilastotiedote 26/2008. Viitattu 11.1.2018.

https://julkari.fi/bitstream/handle/10024/77943/tt26 08.pdf?sequence=1.

Kelan kuntoutuspalvelut 2019. Kelan verkkosivusto osio Yhteistyökumppanit kuntoutuspalvelut. Viitattu 17.2.2019. https://www.kela.fi/kuntoutuspalvelut.

Kelan kuntoutustilasto 2015. Suomen virallinen tilasto. Sosiaaliturva 2016. Viitattu 5.1.2018.

http://www.kela.fi/documents/10180/1630858/Kelan kuntoutustilasto 2015.pdf/1 9dc66df-4e6b-47bd-bfee-d468ada966ae.

Kestilä, L., Heino, T. \& Solantaus, T. 2011. Nuorten syrjäytyminen -epäsuotuisia polkuja aikuisuuteen. Haaste 1. Viitattu 19.6.2018.

http://www.haaste.om.fi/fi/index/lehtiarkisto/haaste12011/nuortensyrjaytyminenepasuotuisiapolkujaaikuisuuteen.html. 
Kieling, C., Baker-Henningham, H., Belfer, P.M, Conti, G. \& Ertem, I. 2011. Child and adolescent mental health worldwide: evidence for action. Lancet 2011, 378, 9801, 1515-1525.

Kokko, R-L. 2007. Toiveikkuutta ja voimavaroja dialogisesta verkostotyöstä. Kuntoutus 3, 5-23.

Koukkari, M. 2010. Tavoitteena kuntoutuminen - Kuntoutujien käsityksiä kokonaisvaltaisesta kuntoutuksesta ja kuntoutumisesta. Väitöskirja. Rovaniemi: Lapin yliopistokustannus. Viitattu 5.1.2018.

http://lauda.ulapland.fi/bitstream/handle/10024/61643/Koukkari\%20DORIA.pdf?seq $\therefore$

Koskenvuo, K. 2017. Yhä useampi nuori päättyy työkyvyttömyyseläkkeelle. Kansaneläkelaitoksen tutkimusblogi 29.9.2017. Viitattu 4.12.2018. http://blogi.kansanelakelaitos.fi/arkisto/4129.

Kuntoutuksen uudistamiskomitea 2017. Kuntoutuksen uudistamiskomitean ehdotuksen kuntoutusjärjestelmän uudistamiseksi. Sosiaali- ja terveysministeriön raportteja ja muistioita 2017:41. Viitattu 2.2.2019.

http://julkaisut.valtioneuvosto.fi/bitstream/handle/10024/160273/RAP2017 41.pdf.

Kuula, A. 2011. Tutkimusetiikka: aineistojen hankinta, käyttö ja säilytys. Tampere: Vastapaino.

Kuoppala, T. \& Säkkinen, S. Kasvatus- ja perheneuvolatoiminta 2012. 2013.Terveyden ja hyvinvoinninlaitos. Tilastoraportti. Viitattu 11.1.2018.

http://www.julkari.fi/bitstream/handle/10024/110731/Tr31 13.pdf?sequence=4.

Kymalainen, J.A., Henze, K.T., DeLuca, M., Mitton, T.A., Walton, H.M, Duffy, P. Kapungu, C., Lefebvre, T. Alexander, W.H. \& Pinsky, J. 2010. Are Ew There Yet? The Four-Year Impact of a VA Fellowship Program on the Recovery Orientation of Rehabilitation Programs. Psychiatric Rehabilitation Journal 33, 4, 320-327.

Laaksovirta, T.H. 1983. Tieteellinen ajattelu -arkiajattelu. Kirjastotiede ja informatiikka 2, 1, 11-18.

Landa, Y., Mueser, K.T., Wyka, K.E., Shreck, E., Jespersen, R., Jacobs, M.A., Griffin, K.W., van der Gaag, M., Reyna, V.F., Beck, A.T., Silberswieg, D.A. \& Walkup, J.T. 2016. Development of a group and family-based cognitive behavioral therapy program for youth at risk for psychosis. Author manuscript. Julkaistu Early Intervention in Psychiatry marraskuu 2016, 10, 6, 511-521. Viitattu 12.1.2018.

https://www.ncbi.nlm.nih.gov/pmc/articles/PMC5685498/pdf/nihms834362.pdf.

Lecomte, T., Wallace, C.J., Perrault, M. \& Caron, J. 2005. Consumers' Goals in Psychiatric Rehabilitation and Their Concordance With Existing Services. Psychiatric Services 56, 2, 209-211.

Leppänen, V. 2015. Epävakaan persoonallisuuden hoitomallitutkimus Oulun mielenterveyspalveluissa.Väitöskirja. Oulun yliopisto, lääketieteellinen tiedekunta. Viitattu 3.1.2019. http://jultika.oulu.fi/files/isbn9789526209685.pdf. 
Lindström, M., Sjöström, S. \& Lindberg, M. 2013. Stories of Rediscovering Agency: Home-Based Occupational Therapy for People With Severe Psychiatric Disability. Qualitative Health Research 23, 6, 728-740.

Linnakangas, R., Lehtoranta, P., Järvikoski, A. \& Suikkanen, A. 2010. Perhekuntoutuspuntarissa. Kelan psykiatrisen perhekuntoutuksen kehittämishankkeen arviointi. Sosiaali- ja terveysturvan tutkimuksia 109. Kelan tutkimusosasto. Satamala: Vammalan kirjapaino Oy. Viitattu 4.1.2018. https://helda.helsinki.fi/bitstream/handle/10138/17451/Tutkimuksia109.pdf?sequen ce.

Locke, E.A. \& Latham, G.P. 2002. Building a Practically Useful Theoryof Goal Setting and Task Motivation. A 35 -Year Odyssey. American Psychologist 57, 9, 705-717.

Macpherson, R., Jerrom, B., Lott, G. \& Ryce, M. 1999. The outcome of clinical goal setting in mental health rehabiliation service. A model for evaluating clinical effectiveness. Journal of Mental Health 8, 1, 95-102.

McCann, R.A., Armstrong, C.M., Skopp, N.A., Edwards-Stewart, A., Smolenski, D.J., June, J.D.M., Metzger-Abamukong, M. \& Reger, G.M. 2014. Virtual reality exposure therapy for the treatment of anxiety disorders: An evaluation of research quality. Journal of Anxiety Disorders 28, 652-631.

McGuire, A.B., Lysaker, P.H. \& Wasmuth, S. 2015. Altered Self-Experience and Goal Setting in Severe Mental IIIness. American Journal of Psychiatric Rehabiliation 18, 333-362.

Mayer, N., Petrovic, B.R., Grah, M. Loveretic, V. \& Filipcic, I. 2015. Treatment of patients in early phase of psychocic on psychotherapeutic inpatient unit Presentation of the therapeutic programme and evaluation of some aspects. Psychiatria Danubina 29 (3), 447-451.

Mastens, A.S. 2001.Ordinary Magic. Resilience Process in Development. American Psychologist 56, 3, 227-238.

Martin, M. 2016. Nuoruus, vammaisuus ja kuntoutuksen merkitys. Väitöskirja. Lapin yliopisto. Viitattu 4.1.2018.

http://lauda.ulapland.fi/bitstream/handle/10024/62438/Martin_Marjatta_ActaE_19 6 pdfA.pdf?sequence $=2 \&$ isAllowed $=y$.

Mendenhall, A.N. \& Grube, W. 2016. Dveloping a New Approach to Cse Management in Youth Mental Health: Strenghts Model for Youth Case Management. Child Adolescent Social Work Journal 2017, 34, 369-379.

Moilanen, K., Jääskeläinen, E. \& Tolonen, J. 2018. Psykiatrisen kuntoutuksen vaikuttavuus-Retrospektiivinen tutkimus Kuntoutuspalvelut Sähäkässä vuosina 20112016 kuntoutuksessa olleiden nuorten kuntouturprosessin vaikuttavuudesta. Tutkimussuunnitelma 18.1.2018. Pohjois-Pohjanmaan sairaanhoitopiiri, Oulun yliopisto ja Kuntoutuspavelut Sähäkkä Oy.

Moran G.S., Westman, K., Weissberg, E. \&Melamed, S. 2017. Perceived assistance in pursuing personal goals and personal recovery among mental health consumers across housing services. Psychiatry Research 249, 94-101. 
Morgan, D.L. 2014. Integrating Qualitative and Quantitative Methods. A Prgamatic Approach. USA: SAGE.

Morin, L. \& Franck, N. 2017. Rehabilitation Interventions to Promote recovery from Schizophrenia: A Systematic Review. Frontiers in Psychiatry 8 , artikkeli 100, 1-12.

Noelen-Hoeksema, S., Fredrickson, B., Loftus, G.R. \& Lutz, C. 2014. Atkinson \& Hilgard`s Introduction to psychology. 16th edition. China: RR Donelly.

Norton, A.R., Abbott, M.J., Norberg, M.M. \& Hunt, C. 2015. A Systematic Review of Mindfulness and Acceptance-Based Treatments for Social Anxiety Disorder. Journal of Clinical Psychology. 71, 4, 283-302.

NUOTTI-valmennus. 2018. Kelan verkkosivuston osio Yhteistyökumppanit. Viitattu 2.1.2019. https://www.kela.fi/nuottivalmennus.

Nurmi, J-E. 1992. Age Differences in adults` life goals, concerns, an their temporal extensions: A life course approach to future-oriented motivation. International Journal of Behavioral Development 15, 487-508.

Nurmi, J-E. \& Salmela-Aro, K. 2000. Ihmisen psykologinen kehitys ja elämänkulku. Julkaisussa Suomalainen elämänkulku. Toim. E. Heikkinen \& J. Tuomi. Vantaa: Tummavuoren kirjapaino Oy, 86-98.

Nurmi, J-E., Ahonen, T., Lyytinen, H., Lyytinen, P., Pulkkinen, L. \& Ruoppila, I. 2014. Ihmisen psykologinen kehitys. Juva: PS-kustannus.

OPI-kurssit 2016. Kelan verkkosivusto osio yhteistyökumppanit. Viitattu 2.1.2019. https://www.kela.fi/opi-kurssi.

OPI-kuntoutuskurssien tutkimus 2018. Kelan verkkosivusto osio Yhteistyökumppanit. Viitattu 2.1.2019. https://www.kela.fi/opi-kuntoutus.

Opiskeluvalmennus-projekti 2016-2020. 2018. Kelan verkkosivusto osio yhteistyökumppanit. Viitattu 2.1.2019. https://www.kela.fi/opiskeluvalmennus.

Pietarinen, J. 1994. Itsemäärääminen ja itsemääräämisoikeus. Teoksessa Oikeus itsemääräämiseen. Toim. J.Pietarinen, V.Launis, J.Räikkä, E. Lagerspetz, M. Rauhala \& M. Oksanen. Helsinki: Painatuskeskus.

Piha, J. \& Tainio, V-M. 2016. Mielenterveyskuntoutus. Julkaisussa lastenpsykiatria ja nuorisopsykiatria. Toim. K. Kumpulainen, E. Aronen, H. Ebeling, E. Laukkanen, M. Marttunen, K. Puura \& A. Sourander. 2016. Talinna: Duodecim, 681-687.

Pohjola, S. \& Roivanen, J. 2016. Tavoitteiden asetteluun lisää tarkkuutta. Fysioterapia 7, 47-50.

Positiivinen mielenterveys. 2018. Terveyden ja hyvinvoinninlaitoksen verkkosivusto mielenterveyden edistäminen. Viitattu 1.2.1019.

https://thl.fi/fi/web/mielenterveys/mielenterveyden-edistaminen/positiivinenmielenterveys.

Puumalainen, J., Härkäpää, K. \& Järvikoski, A. 2014. Odotukset, osallisuus ja koetut vaikutukset: Osallistujien kokemuksia vaikeavammaisten lääkinnällisestä kuntoutuksesta. Kuntoutus 4, 5-19. 
Pylkkänen, K. 2008. Nuoret aikuiset ja työikäiset. Kappaleessa Muut kuin psykoottiset häiriöt. Tekijät K. Pylkkänen \& I, Moilanen. Teoksessa Kuntoutus. Toim. P. Rissanen, T. Kallaranta \& A. Suikkanen. Helsinki: Duodecim, 167-190.

RAISE Questions and Answers 2017. National Institute of Mental Health verkkosivusto osio RAISE. Viitattu 12.1.2018.

https://www.nimh.nih.gov/health/topics/schizophrenia/raise/raise-questions-andanswers.shtml\#16.

Raivio, H. 2018. Tiivistelmä. Teoksessa Enemmän sosiaalista toimintakykyä, lisää osallisuutta! Yhteiskehittäen vaikuttavampaa sosiaalista kuntoutusta. Sosiaalisen kuntoutuksen kehittämisenhankkeen (SOSKU) 2015-2018 loppuraportti. Terveyden ja hyvinvoinninlaitoksen työpapereita 7/2018. Viitattu 27.12.2018.

http://www.julkari.fi/bitstream/handle/10024/136144/URN ISBN 978-952-343-0709.pdf? sequence $=1$ \&isAllowed $=y$.

Reimer,B. 2004. Social Exclusion in a Comparative Centext. Sociologia Ruralis 44, 1, 76-94. Viitattu 27.12.2018.

https://onlinelibrary.wiley.com/doi/epdf/10.1111/j.1467-9523.2004.00263.x.

Rodriguez-Blanco, L., Lubrini, G., Vidal-Marino, C., Rios-Lago, M. 2017. Efficacy of cognitive rehabilitation of attention, executive functions, and working memory in psychotic disorders: A systematic review. Actas Espanolas de psiquiatria 45, 4, 167178.

Salkind, N.J. 2010. Retrospective Study. Encyclopedia of Research Desing. USA: SAGE. Viitattu 25.6.2018: http://dx.doi.org/10.4135/9781412961288.

Salminen, A-L. 2017. Kuntoutus ja kuntoutuminen tutkimuksen kohteena. Miten tutkia kuntoutusta-Voiko näytön pyramidia avata? Seminaari. Kansaneläkelaitos 15.11.2017. Katsottavissa 26.6.2018. http://videonet.fi/web/kela/20171115/.

Santalahti, P., Sourander, A. \& Piha, J. 2009. Lasten mielenterveyspalveluiden käyttö. Duodecim 125, 959-964. Viitattu 11.1.2018.

http://www.duodecimlehti.fi/api/pdf/duo98033.

Schindler, V.P. 2009. A Client-Centred, Occupation-Based Occupational Therpay Programme for Adults with Psychiatric Diagnoses. Occupational Therapy International 2010, 17, 105-112.

Schindler, V.P. \& Sauerwald, C. 2009. Outcomes of a 4-year program with higher education and employment goals for individuals diagnosed with mental illness. Work 46, 325-336.

Shadmi, E., Gelkopf, M., Garber-Epstein, P., Baloush-Kleinman, V., Dudai, R., Scialom, S.L. \& Roe, D. 2017. Relationship Between Psychiatric-Service Consumers'and Providers 'Goal Concordance and Consumers` Personal Goal Attainment. Psychiatric Services 68, 12, 1312-1314.

Silverman Nair, KP. 2003. Life goals: the concept and its relevance to rehabilitation. Clinical Rehabilitation 17, 192-202.

Skitsofrenia. Käypä hoito -suositus. 2013. Suomalaisen Lääkäriseura Duodecimin ja Suomen Psykiatriyhdistys ry:n asettama työryhmä. Helsinki: Suomalainen 
lääkäriseura Duodecim. Viitattu 3.1.2019.

http://www.terveysportti.fi/xmedia/hoi/hoi35050.pdf.

Sosiaali- ja terveysministeriö 2016. Sosiaali- ja terveydenhuollon kansallinen kehittämisohjelma (KASTE 2012-2015) Ulkoinen arviointi -loppuraportti. Helsinki: Sosiaali- ja terveysministeriö. Viitattu 27.12.2018.

http://julkaisut.valtioneuvosto.fi/bitstream/handle/10024/74895/Rap\%20ja\%20mui 201616 PDF.pdf.

Sourander, A. \& Marttunen, M. 2016 Lasten ja nuorten mielenterveyden häiriöiden epidemologia. Julkaisussa lastenpsykiatria ja nuorisopsykiatria. Toim. K. Kumpulainen, E. Aronen, H. Ebeling, E. Laukkanen, M. Marttunen, K. Puura \& A. Sourander. 2016. Talinna: Duodecim, 116-124.

Suomen virallinen tilasto. 18.6.2018. Väestönrakenne. Tilastokeskus. Viitattu 19.6.2018.

https://www.tilastokeskus.fi/tup/suoluk/suoluk vaesto.html\#väestönikärakenne31.1 $\underline{2}$.

Svedberg, P., Svensson, B., Hansson, L. \& Jormfeldt, H. 2014. A 2-year follw-up study of people with severe mental illness involved in psychosocial rehabilitation. Nordic Journal os Psychiatry 68 , 6, 401-408.

Swildens, W., van Busschbach, J.T., Michon, H., Kroon, h., Koeter, M.W.J., Wiersma, D. \& van Os, J. 2011. Effectively Working on Rehabilitation Goals: 24-Month Outcome of a Randomized Controlled Trial of the Boston Psychiatric Rehabilitation Approach. Canadian Journal of Psychiatry 56, 12, 751-760.

Tabak, N.T. \& Link, P.C. 2015. Goal Attainment Scaling: Tracking Goal Achievement in Consumers with Serious Mental Illness. American Journal of Psychiatric Rehabilitation 18, 173-186.

Tan, B-L., Ng, W-Y., Sudhasan, J., Chng, T., Mok, I. \& Lee, J. 2018. Factors Associated with Changes in Commuity Ability and Recovery After Psychiatric Rehabiliation: A Retrospective Study. Community Mental Health Journal. Published online 26 February 2018. Viitattu 26.12.2018.

https://link.springer.com/article/10.1007\%2Fs10597-018-0249-5.

Toimintakyky ICF -luokituksessa. 2016. Terveyden ja hyvinvoinninlaitoksen verkkosivusto osio toimintakyky. Viitattu 27.6.2018.

https://thl.fi/fi/web/toimintakyky/mita-toimintakyky-on/toimintakyky-icfluokituksessa.

Toivonen, S. 2010. GAS -menetelmä: Fiksusta tavoitteen asettamisesta tavoitteen toteutumisen arviointiin. Fysioterapia 7, 22-26.

Toli, A., Webb, T.L. \& Hardy, G.E. 2016. Does forming implementation intentions help people with mental health problems to achieve goals? A meta-analysis of experimental studies with clinical and analogue samples. British Journal of Clinical Psychology 55, 69-90.

Tuomi, J. \& Sarajärvi, A. 2018. Laadullinen tutkimus ja sisällön analyysi. Uudistettu laitos. Helsinki: Tammi. E-kirja. 
Tuori, T., Sohlman, B. Ekqvist, M. \& Solantaus, T. 2006. Alaikäisten psykiatrinen sairaalahoito Suomessa 1995-2004. Stakes, raportteja 13/2006. Helsinki: Stakes. Viitattu 11.1.2018. http://www.stakes.fi/verkkojulkaisut/raportit/R13-2006VERKKO.pdf.

Ungar, M. \& Ghazinour,M. \& Richter, J.2013. Annus research review: What is resilience within the social ecology of human development? Journal of Child Psychology and Psychiatry $54,4,248-366$.

Uusia kursseja mielenterveyskuntoutujille 2017. Kelan verkkosivusto osio tietoa kelasta. Viitattu 2.1.2019. https://www.kela.fi/-/uusia-kurssejamielenterveyskuntoutujille.

Viertiö, S., Mehtälä, T. \& Sailas, E. 2016. Skitsofrenian uudet psykososiaaliset hoidot. Duodecim 132, 7, 632-638.

Whiteford, H.A., Degenhardt, L., Rehm, J., Baxter, A.J., Ferrari, A.J., Erskine, H.E., Charlson, F.J., Norman, R.E., Falxman, A.D., Johns, N., Burstein, R., Murray, C.J.L. \& Vos, T. 2013. Global burden of disease attributable to mental and substance use disorders: findings from the Global Burden of Disease Study 2010. The Lancet 382, 9904, 1535-1586.

World Health Organization. 1998. Health Promotion Glossary. Switzerland: WHO. Viitattu 27.6.2018.

http://www.who.int/healthpromotion/about/HPR\%20Glossary\%201998.pdf. 


\section{Liitteet}

Liite 1. Taulukko 1 Ikätasoiset. toiminnalliset roolit pääkatagorian muodostuminen

\begin{tabular}{|c|c|c|c|}
\hline Sisältöyksikkö & Alempi alaryhmä & Ylempi alaryhmä & $\begin{array}{l}\text { Pääkate- } \\
\text { goria }\end{array}$ \\
\hline \multicolumn{3}{|c|}{ Itsenäinen asuminen } & \multirow{13}{*}{$\begin{array}{l}\text { Ikätasoi- } \\
\text { set toi- } \\
\text { minnalli- } \\
\text { set roolit }\end{array}$} \\
\hline "Asua omillaan" & & \multirow[t]{2}{*}{ Itsenäinen asuminen } & \\
\hline $\begin{array}{l}\text { "siirtyminen vaiheelle 3. it- } \\
\text { senäistymisyksikköön" }\end{array}$ & $\begin{array}{l}\text { Asumiskuntoutusohjel- } \\
\text { massa eteneminen }\end{array}$ & & \\
\hline \multicolumn{3}{|c|}{ Autonomian saavuttaminen } & \\
\hline $\begin{array}{l}\text { "itsenäistymään perhees- } \\
\text { tään" }\end{array}$ & & $\begin{array}{l}\text { Itsenäistyminen van- } \\
\text { hemmista }\end{array}$ & \\
\hline $\begin{array}{l}\text { "Oppia sietämään yksin- } \\
\text { oloa paremmin" }\end{array}$ & & $\begin{array}{l}\text { Turvallisuuden tun- } \\
\text { teen saavuttaminen }\end{array}$ & \\
\hline \multicolumn{3}{|c|}{ Toimintakyky } & \\
\hline $\begin{array}{l}\text { "artkisten taitojen opettelu } \\
\text { ja ylläpitäminen (siivous, } \\
\text { ruuan valmistus, asioiden } \\
\text { hoito)" }\end{array}$ & & $\begin{array}{l}\text { Päivittäisten toimin- } \\
\text { tojen harjoittelu ja } \\
\text { hallinta }\end{array}$ & \\
\hline $\begin{array}{l}\text { "Oma-aloitteisuuden li- } \\
\text { sääntyminen asioinneissa" }\end{array}$ & & \multirow[t]{2}{*}{$\begin{array}{l}\text { Välineelliset päivittäi- } \\
\text { set toiminnot }\end{array}$} & \\
\hline $\begin{array}{l}\text { "Tarkoituksena on hyödyn- } \\
\text { tää myöhemmin budjetti- } \\
\text { laskuria ja mahdollisesti } \\
\text { toista käyttötiliä rahan } \\
\text { käytön hallinnassa" }\end{array}$ & Talouden hallinta & & \\
\hline "itsestä huolehtiminen" & & \multirow[t]{2}{*}{ Itsestä huolehtiminen } & \\
\hline $\begin{array}{l}\text { "Reseptien uusimisen } \\
\text {...tehnyt sovitusti ja itsenäi- } \\
\text { sesti" } \\
\text { "Lääkkeestä..psykoosioirei- } \\
\text { siin..Jatkossa valmis harkit- } \\
\text { semaan sen kokeilemista } \\
\text { uudelleen" }\end{array}$ & $\begin{array}{l}\text { Lääkehoidon toteuttami- } \\
\text { nen }\end{array}$ & & \\
\hline $\begin{array}{l}\text { "aloittelamassa itsenäisiä } \\
\text { harrastuksia asumiskun- } \\
\text { toutuksen ulkopuolella" }\end{array}$ & & Vapaa-ajan toiminnot & \\
\hline
\end{tabular}




\begin{tabular}{|l|l|l|}
\hline $\begin{array}{l}\text { "toimintaympäristön rau- } \\
\text { hallisuuteen tulee kiinnit- } \\
\text { tää erityistä huomiota" }\end{array}$ & $\begin{array}{l}\text { Ympäristön muokkaami- } \\
\text { nen }\end{array}$ & Ympäristö \\
\hline \multicolumn{2}{|c|}{ Käyttäytymisen hallinta } \\
\hline $\begin{array}{l}\text { "Tavoitteena ollut keinojen } \\
\text { löytyminen aggressiivisen } \\
\text {...käytöksen vähentämi- } \\
\text { seen" } \\
\text { "itsetuhoisuuden lisäänty- } \\
\text { misenä" }\end{array}$ & $\begin{array}{l}\text { Muiden- ja itsen va- } \\
\text { hingoittamisen vält- } \\
\text { täminen }\end{array}$ \\
\hline $\begin{array}{l}\text { "ajoittain hän repsahtaa } \\
\text { esim. nettiostoihin tai net- } \\
\text { tipeliin" }\end{array}$ & & \\
\hline $\begin{array}{l}\text { "Saada päihteiden käyttö } \\
\text { hallintaan" }\end{array}$ & & $\begin{array}{l}\text { Impulssikontrollinen } \\
\text { saavuttaminen }\end{array}$ \\
\hline
\end{tabular}


Liite 2. Taulukko 2. Sosiaalinen osallisuus pääkategorian muodostuminen

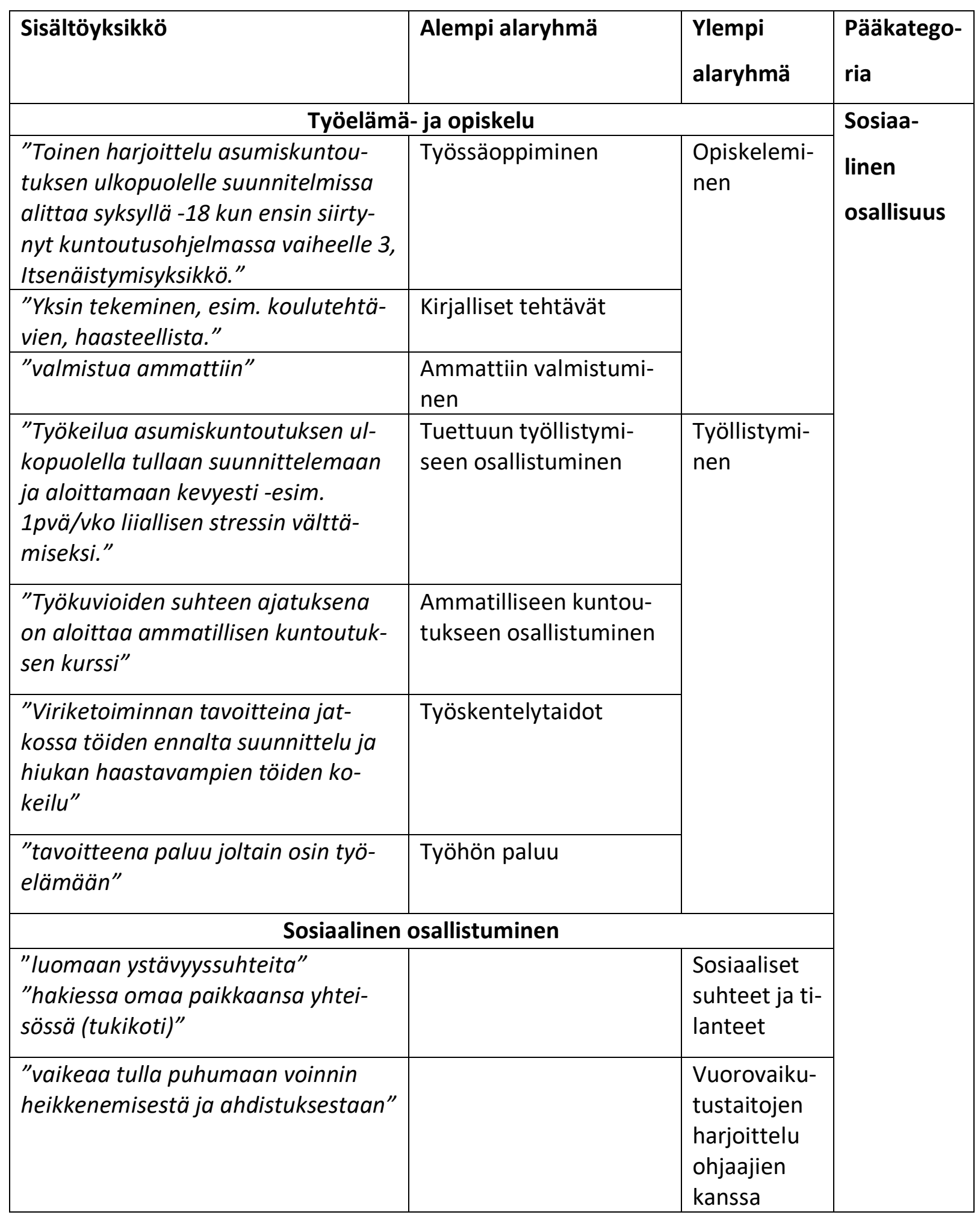


Liite 3. Taulukko 3. Sisäinen resilienssi pääkategorian muodostuminen

\begin{tabular}{|c|c|c|c|}
\hline Sisältöyksikkö & Alempi alaryhmä & Ylempi alaryhmä & Pääkategoria \\
\hline \multicolumn{3}{|c|}{ Psyykkisen terveydentilan edistäminen } & \multirow{14}{*}{$\begin{array}{l}\text { Sisäinen } \\
\text { resilienssi }\end{array}$} \\
\hline $\begin{array}{l}\text { "Kuntoutuksen tavoit- } \\
\text { teena ollut psyykkisen } \\
\text { voinnin tasaantumi- } \\
\text { nen" }\end{array}$ & & $\begin{array}{l}\text { Psyykkisen terveydenti- } \\
\text { lan arviointi ja seuranta }\end{array}$ & \\
\hline $\begin{array}{l}\text { "keskitytty epävakaan } \\
\text { persoonallisuushäiriön } \\
\text { ymmärtämiseen" }\end{array}$ & & \multirow[t]{3}{*}{ Psykoedukaatio } & \\
\hline $\begin{array}{l}\text { "stressinhallinnan kei- } \\
\text { nojen opettelua" }\end{array}$ & Stressin hallinta & & \\
\hline $\begin{array}{l}\text { "sairaus jää yhä } \\
\text { enemmän taka-alalle" }\end{array}$ & $\begin{array}{l}\text { Sairauteen liittyvistä } \\
\text { toimintamalleista } \\
\text { luopuminen }\end{array}$ & & \\
\hline $\begin{array}{l}\text { "Oireidenhallintakei- } \\
\text { noja on käyty yhdessä } \\
\text { läpi" }\end{array}$ & & Oireidenhallinta & \\
\hline \multicolumn{3}{|c|}{ Valtaistuminen } & \\
\hline \multirow{2}{*}{$\begin{array}{l}\text { "tavoitteena myös it- } \\
\text { setunnon kohentumi- } \\
\text { nen" }\end{array}$} & & \multirow[t]{4}{*}{$\begin{array}{l}\text { Itsetunnon vahvis- } \\
\text { tuminen }\end{array}$} & \\
\hline & $\begin{array}{l}\text { Onnistumisen koke- } \\
\text { musten saaminen }\end{array}$ & & \\
\hline $\begin{array}{l}\text { "tavoitteena on lisätä } \\
\text { itsetuntemusta" }\end{array}$ & $\begin{array}{l}\text { Itsetuntemuksen li- } \\
\text { sääntyminen }\end{array}$ & & \\
\hline $\begin{array}{l}\text { "tuetaan nuoren aikui- } \\
\text { sen roolin vahvistumi- } \\
\text { sessa" }\end{array}$ & $\begin{array}{l}\text { Yksilön toimivien } \\
\text { puolin vahvistumi- } \\
\text { nen }\end{array}$ & & \\
\hline $\begin{array}{l}\text { "vastuun ottamisen li- } \\
\text { sääntyminen" }\end{array}$ & & \multirow[t]{2}{*}{ Vastuun lisääntyminen } & \\
\hline $\begin{array}{l}\text { "Tuetaan päätöksen- } \\
\text { teossa" }\end{array}$ & Päätöstentekokyky & & \\
\hline $\begin{array}{l}\text { "elämänhallinnan tai- } \\
\text { tojen kehittäminen" } \\
\text { "arjenhallinnan taito- } \\
\text { jen kehittäminen" }\end{array}$ & & Elämänhallinta & \\
\hline
\end{tabular}




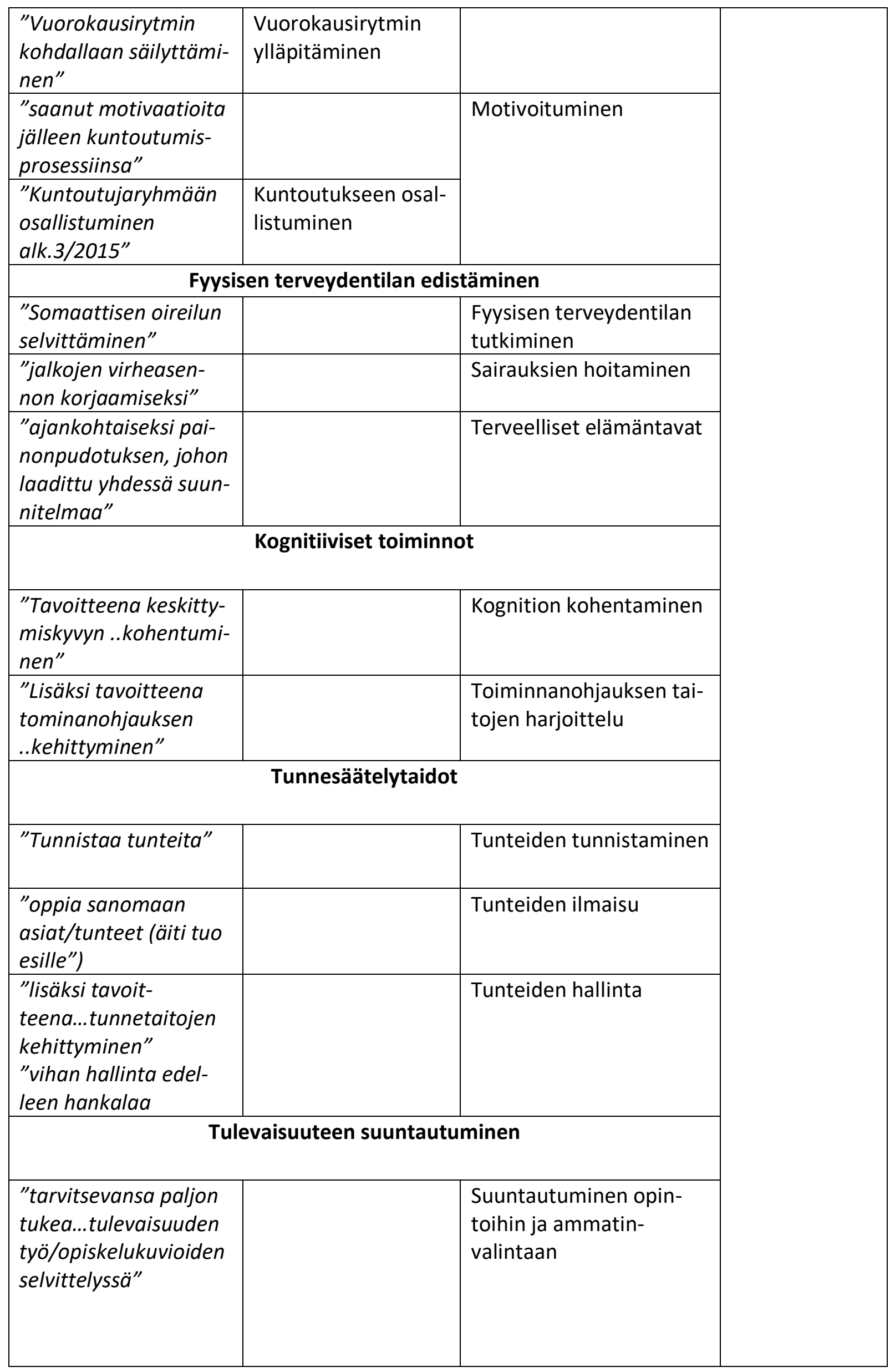




\section{Liite 4. Lupa-asiakirja}

\section{Psykiatrisen kuntoutuksen vaikuttavuus \\ TIEDOTE TUTKITTAVILLE JA SUOSTUMUS TUTKIMUKSEEN OSALLISTUMISESTA}

\section{Tutkimuksen tarkoitus, tavoite ja merkitys}

Sinua pyydetään mukaan tutkimukseen, jossa tutkitaan psyykkisesti oireileville nuorille aikuisille suunnatun psykiatrisen kuntoutuksen tehoa. Tutkimuksessa tarkastellaan miten itsestä huolehtiminen, arjentaitojen, vapaa-ajan ja työelämän tavoitteet ovat toteutuneet. Lisäksi tarkastellaan, onko kuntoutus toteutunut oikeaan aikaan. Tutkimme myös, voiko kuntoutuksen alkuvaiheen toimintakyky tai elämäntilanne ennustaa kuntoutuksen tuloksellisuutta. Lisäksi kartoitamme kyselytutkimuksella kuntoutuksen jälkeistä psykiatrista hoitoa, elämäntilannetta ja tyytyväisyyttä sekä omaa arviotasi kuntoutuksen vaikuttavuudesta.

\section{Tutkimusaineiston käyttötarkoitus, käsittely ja säilyttäminen}

Keräämme tutkimuksessa tietoa Kuntoutuspalvelut Sähäkkä Oy:ssa ajanjaksolla tammikuu 2011elokuu 2016 olleista kuntoutujista. Tiedot kerätään pääosin Sähäkkä Oy:n sähköisestä järjestelmästä. Järjestelmään on kerätty tietoa kuntoutuksen aikana mm. kuntoutustoimenpiteistä, kuntoutukseen osallistumisesta ja sen etenemisestä, lääkityksen käytöstä, kuntoutusmotivaatiosta sekä mikäli kuntoutus on keskeytynyt siihen johtaneista syistä.

Suurin osa tutkimuksessa käytettävistä tiedosta on sähköisenä ja suojattu pankkisalauksen tasoisesti. Tässä tutkimuksessa tutkittavat henkilöt numeroidaan ja tunnistetiedot poistetaan, jolloin tutkimuksen aikana tutkijoiden ei ole mahdollista tietää tutkittavien henkilöllisyyttä. Kaksi tutkijoista työskentelee kuntoutustyössä Sähäkässä ja heidän osaltaan tunnistaminen on mahdollista. Näillä henkilöillä on lupa tutustua työnsä puolesta kyseessä oleviin tietoihin. Tutkittaviin liittyvään kirjalliseen materiaaliin on pääsy vain tutkijoilla. Sähköinen materiaali on nimetöntä, ja tämä materiaali säilytetään tietoturvavaatimusten vaatimalla tavalla. Tutkimuksesta on täytetty henkilötietolain edellyttämä rekisteriseloste, jonka saat halutessasi nähtäväksesi.

Tutkimuksen päätyttyä tutkimusaineisto arkistoidaan Oulun yliopiston ylläpitämään sähköiseen, suojattuun tietoarkistoon myöhempää tutkimuskäyttöä varten. Arkistoiva aineisto ei sisällä tutkittavan tunnistetietoja.

\section{Tutkimukseen osallistuminen}

Pyydämme suostumustasi osallistua tähän tutkimukseen ja käyttää tietojasi tässä tutkimuksessa. Osallistuminen tutkimukseen on täysin vapaaehtoista. Sinulla on tutkimuksen aikana oikeus kieltäytyä tutkimuksesta ja keskeyttää tutkimukseen osallistuminen missä vaiheessa tahansa ilman, että siitä aiheutuu sinulle mitään seuraamuksia. Tutkimuksen järjestelyt ja tulosten raportointi ovat luottamuksellisia. Tutkimuksesta saatavat tutkittavien tiedot tulevat ainoastaan tutkittavan ja tutkijaryhmän käyttöön ja tulokset julkaistaan tutkimusraporteissa siten, ettei yksittäistä tutkittavaa voi tunnistaa. Voit saada lisätietoa tutkimuksesta tutkijaryhmän jäseniltä missä vaiheessa tahansa.

\section{Tutkimuksen hyödyt ja haitat}

Tutkimuksesta ei aiheudu sinulle suoraa riskiä, koska suurin osa tutkimuksessa käytettävistä aineistoista on jo kerätty. Voit ottaa yhteyttä tutkijoihin, mikäli esimerkiksi kyselylomakkeeseen vastaaminen tai yleisesti tutkimukseen osallistuminen aiheuttaa sinulle kysymyksiä tai psyykkistä oireilua. 
Coronaria Sähäkkä Oy:n toiminta ja henkilöstö on vakuutettu, ja tämä vakuutus on voimassa myös tämän tutkimuksen aikana. Vakuutus sisältää potilasvakuutuksen, toiminnanvastuuvakuutuksen ja vapaaehtoisen tapaturmavakuutuksen.

\section{Miten ja mihin tutkimustuloksia aiotaan käyttää}

Tutkimustuloksista aiotaan kirjoittaa 2-4 artikkelia alan julkaisuihin.

Toimintaterapeutti Jonna Tolonen tekee osana tutkimushanketta ylemmän ammattikorkeakoulun opinnäytetyön. Opinnäytetyön tarkoituksena on tutkia kuntoutukselle asetettuja tavoitteita sekä niiden toteutumisesta kuntoutumisen aikana.

Tutkimustuloksia hyödynnetään Coronaria Sähäkkä Oy:n toiminnan kehittämisessä sekä markkinoinnissa. Lisäksi tuloksia saatetaan esitellä konferensseissa tai seminaareissa.

Tutkimuksen tuloksista annetaan sinulle tietoa sähköisesti, esimerkiksi Coronaria Sähäkkä Oy:n internet ja facebook-sivuston kautta.

Tutkimuksesta vastaava henkilö:

Muut tutkijat: 


\section{Tutkittavan suostumus tutkimukseen osallistumisesta}

Olen perehtynyt tämän tutkimuksen tarkoitukseen ja sisältöön, kerättävän tutkimusaineiston käyttöön, minulle aiheutuviin mahdollisiin haittoihin, hyötyihin, oikeuksiin ja vakuutusturvaan.

Suostun osallistumaan tutkimukseen annettujen ohjeiden mukaisesti. Tätä suostumusasiakirjaa on tehty kaksi $(2 \mathrm{kpl})$, joista toinen annetaan tutkittavalle ja toinen suostumuksen vastaanottajalle.

Voin halutessani peruuttaa tai keskeyttää osallistumiseni tai kieltäytyä tutkimukseen osallistumisesta missä vaiheessa tahansa.

Tutkimustuloksia ja kerättyä aineistoa saa käyttää ja hyödyntää sellaisessa muodossa, jossa minua ei voi tunnistaa.

Tarvitsen edunvalvojan allekirjoituksen suostumuslomakkeeseen, mikäli minut on todettu vajaavaltaiseksi.

Suostun minusta kerätyn aineiston arkistointiin tunnistetiedottomana

KYLLÄ

EI

Nimi:

Syntymäaika:

Osoite:

Puhelinnumero:

Sähköpostiosoite:

Päiväys $\quad$ Tutkittavan/edunvalvojan allekirjoitus

Päiväys $\quad$ Tutkijan allekirjoitus


Liite 5. Muistutus osallistumisesta tutkimukseen

Psykiatrisen kuntoutuksen vaikuttavuus

\section{Muistutus tiedotteesta ja suostumuksesta tutkimukseen}

Lähetimme sinulle tiedotteen ja suostumuksen tutkimukseen Psykiatrisen kuntoutuksen vaikuttavuus. Jos et vielä ole palauttanut suostumusta, siihen on aikaa 30.3.2018 saakka. Jokaisen osallistujan saaminen mukaan tutkimukseen on tärkeää, jotta tulokset olisivat mahdollisimman kattavat.

Tulemme kevään 2018 aikana lähestymään osallistuneita kyselyllä, toiveesi mukaan sähköisesti tai postin kautta.

Tutkimuksesta vastaava henkilö:

Muut tutkijat: 